\title{
Przegląd lekkich wieloczlonowych pojazdów szynowych z napędem spalinowo-elektrycznym
}

\begin{abstract}
W artykule przedstawiono opisy lekkich wieloczlonowych pojazdów szynowych do obstugi ruchu regionalnego. Zaprezentowano wymagania stawiane przede wszystkim uktadom napędowym $i$ wchodzacym w ich skład głównym urzqdzeniom i maszynom. W szczególności skupiono się na opisach układów napędowych spalinowo-elektrycznych, w tym ich głównych urzqdzeń, stosowanych zarówno w spalinowych zespołach trakcyjnych jak $i$ w autobusach szynowych. Artykut powstat w wyniku realizacji prac studialnych projektu badawczego $\mathrm{nr} 4$ T12DO1227 pt. "Spalinowo-elektryczny napęd dla lekkich wieloczłonowych pojazdów szynowych"
\end{abstract}

\section{WSTĘP}

Lekkie jedno- i wieloczłonowe pojazdy szynowe, najczęściej z napędem spalinowym, eksploatowane są $\mathrm{z}$ powodzeniem od kilkudziesięciu lat do przewozu osób przede wszystkim na liniach znaczenia miejscowego i lokalnego $[1,10]$.

Pojazdy te znalazły zastosowanie zwłaszcza ze względu na: swoją taniość w stosunku do pociagów złożonych z lokomotywy i wagonów pasażerskich, mimo ograniczonej wytrzymałości pudła duże bezpieczeństwo oraz duże możliwości dostosowawcze dla potrzeb klientów.

Ze względu na konfigurację zewnętrzną i wewnętrzną lekkie pojazdy szynowe można podzielić na:

- wagony motorowe - samodzielne pojazdy jednoczłonowe $\mathrm{z}$ napędem, ciagnące często wagon lub wagony pasażerskie

- spalinowe zespoły trakcyjne najczęściej wieloczłonowe (dwu-, trzy-, -cztero-) pracujacce jako jednostki samodzielne

- autobusy szynowe najczęściej jedno-, dwu-, trzy- lub czteroczłonowe.

W lekkich pojazdach szynowych bardzo ważnym jest układ napędowy tzn. zespół urządzeń służących do przeniesienia momentu obrotowego, wytwarzanego przez jednostkę napędowa, na osie napędowe pojazdu.

W zależności od rodzaju napędu rozróżnia się lekkie pojazdy szynowe z $[11,12]$ :

- napędem elektrycznym i przekładnia elektryczną

- napędem spalinowym i przekładnią hydrauliczną (hydromechaniczną) lub elektryczną

- napędem hybrydowym tzn. łączącym cechy napędu elektrycznego (eksploatacja na liniach zelektryfikacyjnych) oraz spalinowoelektrycznego (eksploatacja na liniach niezelektryfikowanych).

Wszystkie rodzaje napędów są realizowane w pojazdach wyposażonych w wózki jedno- lub dwuosiowe.
W dalszej części skupiono się tylko na lekkich pojazdach szynowych, w których został zastosowany napęd spalinowo-elektryczny i są one z powodzeniem eksploatowane w wielu krajach europejskich.

\section{WYMAGANIA TECHNICZNO-EKSPLOA- TACYJNE DLA POJAZDÓW Z NAPĘDEM SPALINOWO-ELEKTRYCZNYM}

Wymagania jakie stawia się nowoczesnym lekkim pojazdom szynowym wynikają z jednej strony ze zdobytych doświadczeń w eksploatacji już wykonanych i wypróbowanych pojazdów (zarówno w kraju jak i za granica), a z drugiej z szybko postępującego rozwoju techniki zarówno w mechanice, a szczególnie w elektrotechnice i energoelektronice oraz są zależne od szczegółowych wymagań potencjalnego nabywcy i użytkownika.

Lekkie pojazdy szynowe do obsługi ruchu lokalnego i regionalnego powinny przede wszystkim charakteryzować się nowoczesnością konstrukcji, a jednocześnie posiadać sprawdzone i niezawodne podzespoły (w szczególności silnika i całego układu przeniesienia napędu). Ponadto pojazdy winny w zakresie konstrukcji, parametrów technicznych i eksploatacyjnych spełniać wymagania odpowiednich norm (krajowych i europejskich), przepisów UIC, zaleceń ERRI i Dyrektyw Unii Europejskiej oraz charakteryzować się prostotą obsługi technicznej i niskimi kosztami eksploatacji.

Ogólne wymagania dla lekkich pojazdów szynowych, w tym również istotne dla układów napędowych, są następujące:

- $\quad$ konfiguracja s; s-s; s-d; s-d-s; d-s-d gdzie s- człon silnikowy (napędowy); d człon doczepny (może być sterujący)

- układ osi w zależności od przyjętej konfiguracji, z wykorzystaniem wózków jedno- i dwuosiowych

- skrajnia wg UIC 505-1 [29] 
- prędkość eksploatacyjna $100 \div 120 \mathrm{~km} / \mathrm{h}$ (dla obsługi ruchu ekspresowego $140 \div 160 \mathrm{~km} / \mathrm{h}$ )

- przyspieszenie rozruchu $\geq 0,5 \mathrm{~m} / \mathrm{s}^{2}$ (zazwyczaj $0,6 \div 0,8 \mathrm{~m} / \mathrm{s}^{2}$ )

- opóźnienie hamowania ok.1,0 m/ $\mathrm{s}^{2}$

- największe wzniesienie, na którym pojazd powinien ruszać $\mathrm{z}$ pełnym obciążeniem $>20 \div 30 \%$

- wytrzymałość P2 lub P3 wg PN-EN 12663 [30] oraz wyposażenie w elementy pochłaniające energię zderzenia czołowego tak, aby przy prędkości nabiegania do $15 \mathrm{~km} / \mathrm{h}$ nie dochodziło do deformacji konstrukcji pudła, a przy prędkościach nabiegania $15 \div 30 \mathrm{~km} / \mathrm{h}$ deformacja pudła nie była większa niż od czoła pojazdu do pomieszczenia dla pasażerów

- jednostkowa moc znamionowa silnika spalinowego $\geq 6,5 \mathrm{~kW} / \mathrm{t}$ masy własnej pojazdu (zazwyczaj $8 \div 10 \mathrm{~kW} / \mathrm{t}$ )

- maksymalny nacisk zestawu kołowego na tor pojazdu $\mathrm{z}$ pełnym obciążeniem ( $\mathrm{w}$ stanie służbowym) $140 \div 160 \mathrm{kN}$ (szczegółowe wymagania zależne od dopuszczalnych nacisków trasy, na której pojazd będzie eksploatowany)

- eksploatacyjny zakres temperatur otoczenia od $-30^{\circ} \mathrm{C}$ do $+40^{\circ} \mathrm{C}$ przy zabezpieczeniu niezawodnej pracy pojazdu w warunkach ostrej zimy (obfite opady śniegu i niskie temperatury) i upalnego lata.

Dla układu napędowego spalinowo-elektrycznego powinno się uwzględniać następujące (najważniejsze) kryteria wyjściowe:

- nowoczesność rozwiązań na miarę krajowych potrzeb i oczekiwań

- przewidywana konfiguracja nadwozia pojazdu

- sposób sterowania napędem

- prędkość maksymalna ze szczególnym względnieniem przewidywanego wachlarza prędkości eksploatacyjnych

- masa własna pojazdu

- warunki eksploatacyjne, w tym usytuowanie linii - tereny nizinne, podgórskie, górskie

- możliwość bezpośredniego wykorzystania bądź adaptacji istniejących rozwiązań z pojazdów szynowych i drogowych dla zmniejszenia kosztów.

Ponadto istotne jest również to, aby układ napedowy nie miał znaczącego wpływu na zmniejszenie funkcjonalności nadwozia jako przestrzeni pasażerskiej i niezbędnej przestrzeni dla obsługi oraz umożliwiał holowanie przy wyłączonym silniku spalinowym bez konieczności rozłączania napędu [12].

Szczególne wymagania i kryteria dla poszczególnych maszyn i urządzeń wchodzących w skład układu spalinowo-elektrycznego są nastęujące:
- $\quad$ silnik spalinowy wysokoprężny o wtrysku bezpośrednim, chłodzony ciecza, spełniajacy wymagania Euro III lub Euro IV oraz UIC II lub UIC IIIa [31] w zakresie emisji składników toksycznych gazów wydechowych do atmosfery, gwarantujacy jednostkowe zużycie paliwa do $200 \mathrm{~g} / \mathrm{kWh}$, a oleju smarnego do $0,5 \%$ zużycia paliwa oraz charakteryzujący się wysoką trwałością i żywotnością liczoną czasem do naprawy głównej powyżej 20 tyś. godzin

- prądnica główna synchroniczna, bezszczotkowa, o zwartej budowie $\mathrm{z}$ wbudowaną na jednym wale wzbudnica, połączona na sztywno lub elastycznie z silnikiem spalinowym; całość powinna tworzyć zespół zabudowany na specjalnej ramie $\mathrm{z}$ możliwością jej podwieszenia pod ostoją wagonu ( $\mathrm{z}$ przodu lub bezpośrednio za wózkiem) lub ustawienia w przedziale maszynowym

- prostownik sterowany lub niesterowany $z$ przewietrzaniem własnym

- przekształtnik (falownik) wykonany w technologii IGBT z przewietrzaniem własnym lub obcym, zabudowany w specjalnej skrzyni pod ostoją lub na dachu, lub w specjalnej szafie do zabudowy wewnątrz pojazdu

- hamulec elektryczny - typu elektrodynamicznego z opornikami zabudowanymi na dachu lub w przedziale maszynowym, działający w całym zakresie prędkości (od max do zatrzymania) i wyposażony w mikroprocesorowy system przeciwpoślizgowy; dobrze gdy energia wytwarzana podczas hamowania może służyć do napędu urządzeń pomocniczych lub ładowania akumulatorów energii

- silnik trakcyjny asynchroniczny prądu przemiennego o mocy zapewniającej właściwe przyspieszenie rozruchu i jego narastanie, budowy zwartej, zawieszony elastycznie na ramie wózka lub pod ostoją

- przekładnia osiowa jedno- lub dwustopniowa przenosząca płynnie moment obrotowy z silnika na zestaw kołowy przy zmianie siły pociaggowej oraz zmianie prędkości pojazdu, budowy zwartej, szczelna i zawieszona elastycznie na ramie wózka.

Ponadto układ napędowy powinien posiadać rozruch impulsowy, mikroprocesorowy układ sterowania oraz mikroprocesorowy system zabezpieczający przed poślizgiem kół.

W zakresie utrzymania lekki pojazd szynowy, a w tym układ napędowy, winien spełniać następujące wymagania:

- wynikające z przewidywanego zakresu obsługi i napraw: 
- możliwość łatwej lokalizacji uszkodzeń zespołów i podzespołów

- wykrywalność uszkodzeń i stanu osiagania wartości granicznych określonych parametrów technicznych, dzięki stosowaniu diagnostyki funkcjonalnej i stacjonarnej

- wynikające $\mathrm{z}$ konieczności zapewnienia podatności naprawczej:

- dostępność do elementów i podzespołów pojazdu oraz niska pracochłonność wymiany podzespołów

- budowa modułowa ułatwiająca demontaż i montaż poszczególnych bloków

- unifikacja części dla ograniczenia niezbędnych narzędzi i oprzyrządowania

- wynikające z konieczności zapewnienia wysokiej trwałości i niezawodności:

- duże przebiegi między przeglądami i naprawami

- wysoki współczynnik gotowości technicznej do wykonywania zadań przewozowych

- żywotność ponad 30 lat,

- w zakresie przystosowania pojazdu i napędu do:

- diagnostyki stacjonarnej i pokładowej

- diagnostyki funkcjonalnej $\mathrm{z}$ zastosowaniem mikrokomputera pokładowego, umożliwiającego uzyskanie informacji o parametrach, których wartość osiąnęła lub przekroczyła wartość krytyczną $\mathrm{z}$ możliwością wydruku wyników pomiarów sygnalizacji obsłudze stanu krytycznego wybranych parametrów (decydujących o bezpiecznej i bezawaryjnej jeździe pojazdu)

- automatycznego pomiaru wybranych parametrów w celu określenia zakresu przeglądu lub naprawy.

3. PRZEGLĄD SPALINOWYCH ZESPOLÓW TRAKCYJNYCH $Z$ NAPECDEM SPALINOWO-ELEKTRYCZNYM
Pierwszymi pojazdami $\mathrm{z}$ napędem spalinowoelektrycznym przeznaczonymi do przewozu pasażerów były wagony motorowe i spalinowe zespoły trakcyjne. Te pierwsze jako jednostki jednoczłonowe mogą ponadto prowadzić jeden lub kilka wagonów osobowych, natomiast drugie są wieloczłonami połączonymi w zasadzie na stałe, gdyż często jeden z członów (lub człony skrajne) jest napędowy, a drugi doczepny lub sterujący.

Większość wagonów motorowych posiada układ napędowy złożony z silnika spalinowego i przekładni mechanicznej lub hydraulicznej, natomiast układy napędowe spalinowych zespołów trakcyjnych są różnorodne.

W dalszej części przedstawiono skrótowe opisy tylko tych zespołów, w których zastosowano napęd spalinowo-elektryczny.

\section{a) Niemiecki zespół trakcyjny serii VT610}

Zespół opracowany i wyprodukowany przez konsorcjum, w skład którego wchodziły firm: MAN/MBB/DUEWAG (część mechaniczna nadwozia), Siemens/AEG/ABB (część elektryczna i wózki) oraz FIAT Ferroviaria (odpowiedzialna za układ przechyłu pudła), wszedł do eksploatacji na początku lat 90-tych XX wieku [4].

Składał się $\mathrm{z}$ dwóch wagonów VT610.0 i VT610.5 o układzie osi 2 (A1) +(1A) (A1).

Ogólny widok zespołu przedstawiono na rys.1.

Zespół jest przeznaczony do ruchu z prędkościami do $160 \mathrm{~km} / \mathrm{h}$, a dzięki zastosowanemu aktywnemu układowi przechyłu pudła może osiągnąć na łukach prędkość do $130 \mathrm{~km} / \mathrm{h}$. Maksymalne naciski zestawu kołowego na tor wózka napędowego nie przekraczają 13,2 t, a wózka tocznego 13,4 t.

Cały napęd i urządzenia (agregaty) pomocnicze zabudowane zostały pod ostojami obu wagonów. Sterowanie zespołu zapewnia system automatyczny SIBAS 16 oparty na technice mikroprocesorowej.

Ogólnie układ napędowy składa się z dwóch silników spalinowych, dwóch prądnic synchronicznych, dwóch przekształtników i trzech silników trakcyjnych.
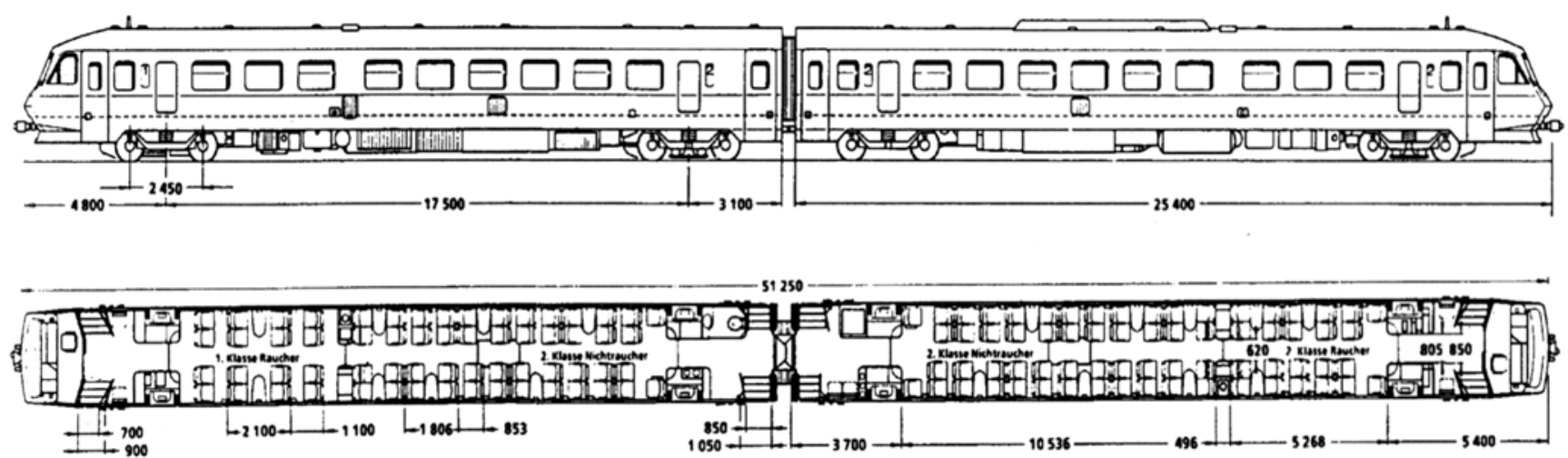

Rys.1. Ogólny widok zespołu serii VT610 
Zasilanie zespołów i urządzeń pomocniczych odbywa się prądem przemiennym $400 \mathrm{~V} 50 \mathrm{~Hz}$ i $230 \mathrm{~V}$ poprzez przekształtnik jednofazowy oparty na tyrystorach GTO.

Drobne urządzenia takie jak oświetlenie, sterowanie, hamulec magnetyczny, systemy bezpieczeństwa oraz rozruszniki silników spalinowych zasilane są napięciem $24 \mathrm{~V}$ prądu stałego.

Zespół jest wyposażony w trzy rodzaje hamulca: hamulec pneumatyczny (mechaniczny typu tarczowego $\mathrm{z}$ hamulcem postojowym), hamulec magnetyczny oraz hamulec elektryczny typu oporowego (hamulec elektrodynamiczny) [9].

\section{b) Zespól serii BM/BS92 dla kolei norweskich}

Zespół został opracowany w 1982r. przez firmę DUEWAG AG, przy czym układ napędowy przygotowany został przez firmę BBC. Pojazdy dostarczone zostały kolejom norweskim na przełomie 1984/1985 roku [8].

Zespół jest pojazdem dwuczłonowym i składa się $\mathrm{z}$ wagonu napędowego (BM) i wagonu sterującego (BS). Przeznaczony jest do ruchu z prędkościami do $140 \mathrm{~km} / \mathrm{h}$. Ogólny widok zespołu przedstawiono na rys.2.

Układ napędowy zespołu tworzą dwa zespoły prądotwórcze (silniki spalinowe - prądnice synchroniczne), przekształtnik trakcyjny oraz dwa asynchroniczne silniki trakcyjne. Część układu zabudowana jest na podwoziu, a część wewnątrz pojazdu [14].

Urządzenia i maszyny napędów pomocniczych zasilane są napięciem $3 \times 220 \mathrm{~V}$ i $3 \times 26 \mathrm{~V}$ poprzez przekształtnik i transformator. Na pojeździe zabudowane są baterie akumulatorów $110 \mathrm{~V}$ prądu stałego. Zespół wyposażony został $\mathrm{w}$ hamulec pneumatyczny (mechaniczny klockowy i tarczowy) oraz hamulec elektrodynamiczny, którego oporniki są zabudowane na dachu wagonu napędowego. Sterowanie zespołu realizuje mikrokomputer - automatyczny system sterujący Micas, który zapewnia również diagnozowanie głównych zespołów i układów [13].

Zespół trakcyjny jest wyposażony w wózki dwuosiowe $\mathrm{z}$ ramami spawanymi oraz zabudowanymi thumikami hydraulicznymi pionowymi i poziomymi, zapewniającymi pewny i stabilny ruch także przy dużych prędkościach.

c) Zespół trakcyjny VT/VS2E heskiej kolei regionalnej

Zespół został zaprojektowany i wyprodukowany przez firmy Linke-Hoffmann-Busch i Asea BrownBoveri z przeznaczeniem do obsługi ruchu regionalnego $\mathrm{z}$ prędkościami do $100 \mathrm{~km} / \mathrm{h}$. Pojazd jest jednostką dwuwagonową o układzie osi $B_{0}^{\prime} 2 B_{0}^{\prime}$ [3].

Ogólny widok zespołu przedstawiono na rys. 3 .

Układ napędowy zespołu, zabudowany na podwoziu obu wagonów, tworzą: silnik spalinowy, prądnica synchroniczna, prostownik i silniki trakcyjne prądu stałego. Obwody pomocnicze zasilane są prądem stałym o napięciu $110 \mathrm{~V}$.

System hamulca zespołu tworzą: hamulec elektryczny (elektrodynamiczny), hamulec powietrzny (pneumatyczny) z tarczami hamulcowymi i zasobnikiem hamulca postojowego oraz hamulec magnetyczny zabudowany na wózkach tocznych.

Sterowanie zespołem i całym układem napędowym zapewnia elektroniczny system Micas firmy ABB. Oba wózki (napędowy i toczny) posiadają w pierwszym stopniu usprężynowania elementy gumo$\mathrm{we}$, a $\mathrm{w}$ drugim stopniu sprężyny pneumatyczne. $\mathrm{Na}$ wózkach napędowych zabudowane są oprócz napędu również piasecznice. Dobre własności biegowe zapewniają thumiki hydrauliczne pionowe i poziome. Podobny w budowie jest pojazd VT70.
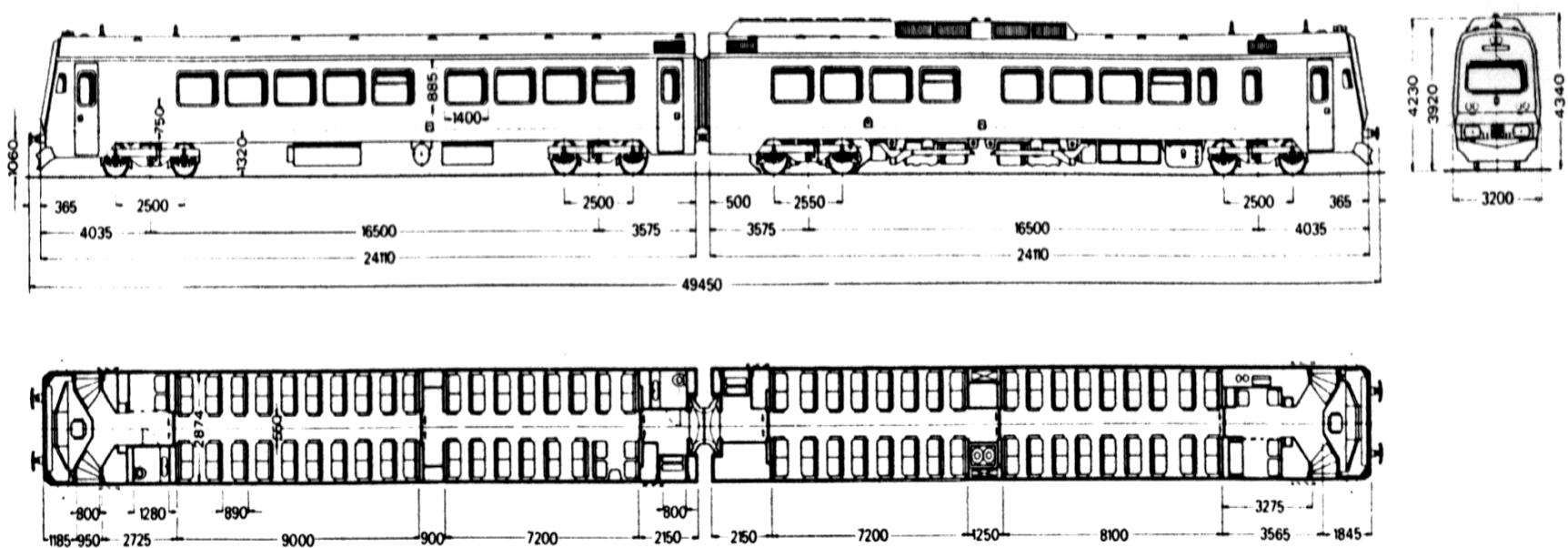

Rys.2. Ogólny widok zespołu serii BM/BS 92 

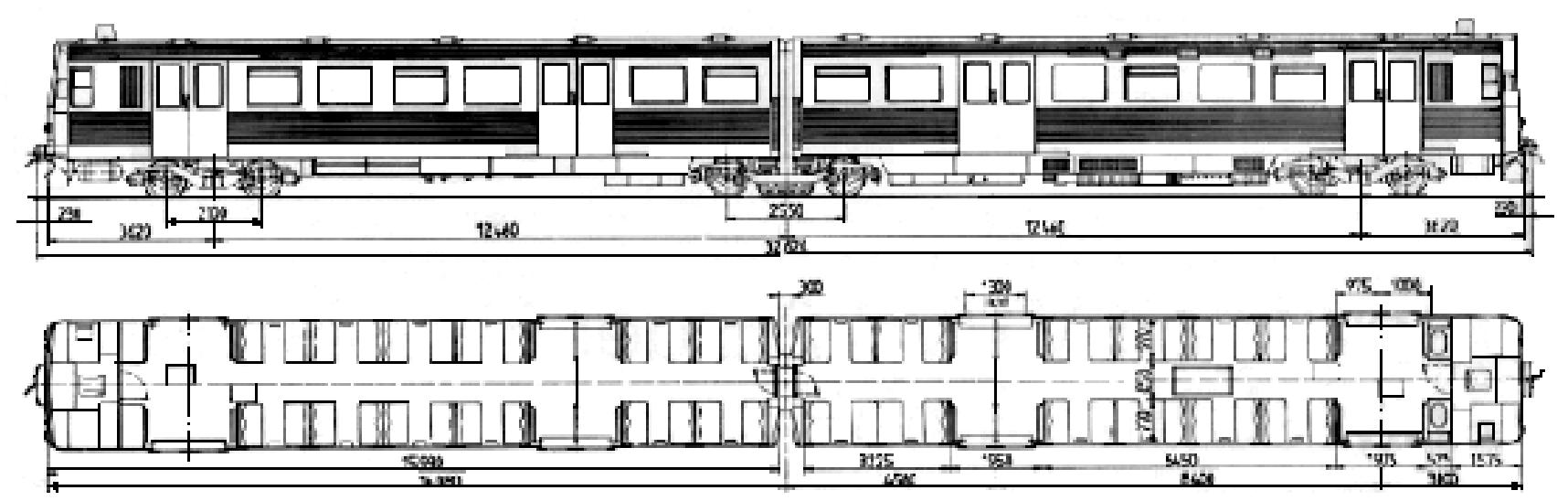

Rys.3. Ogólny widok zespołu trakcyjnego serii VT/VS 2E

Główne parametry wybranych spalinowych zespołów trakcyjnych przedstawiono w tabeli 1.

Lekkie wieloczlonowe pojazdy szynowe ze spalinowo-elektrycznym ukladem napęowym

\begin{tabular}{|c|c|c|c|c|c|}
\hline \begin{tabular}{|r|r|} 
Sarametr & Seria (typ) pojazdu \\
Kraj
\end{tabular} & $\begin{array}{c}\text { Jednostka } \\
\text { miary }\end{array}$ & $\begin{array}{l}\text { VT610 } \\
\text { Niemcy }\end{array}$ & $\begin{array}{l}\text { BM/BS } 92 \\
\text { Norwegia }\end{array}$ & $\begin{array}{l}\text { VT/VS 2E } \\
\text { Niemcy }\end{array}$ & $\begin{array}{l}\text { VT } 70 \\
\text { Austria }\end{array}$ \\
\hline Układ osi & - & $2^{\prime}(\mathrm{A} 1)^{\prime}+(1 \mathrm{~A})^{\prime}(\mathrm{A} 1)^{\prime}$ & $2 \mathrm{~B}_{0}+22^{\prime}$ & $\mathrm{B}_{0}{ }^{\prime} 2 \mathrm{~B}_{0}{ }^{\prime}$ & $\mathrm{B}_{0} 2 \mathrm{~B}_{0}{ }^{\prime}$ \\
\hline Masa własna / napędna & $\mathrm{Mg}$ & 102,4 & 96,9 & - & - \\
\hline $\begin{array}{l}\text { Nacisk zestawu kołowego na tor } \\
\text { (toczny / napędny) }\end{array}$ & $\mathrm{kN}$ & $131,5 / 129,5$ & - & - & - \\
\hline Prędkość max & $\mathrm{km} / \mathrm{h}$ & 160 & 140 & 100 & 95 \\
\hline Długość całkowita pojazdu & m & 51,75 & 49,45 & 32,62 & - \\
\hline $\begin{array}{l}\text { Liczba miejsc siedzących / stojących / } \\
\text { całkowita }\end{array}$ & - & $136 /-/-$ & $146 /-/-$ & $96 / 152 / 248$ & - \\
\hline Rodzaj wózków tocznych / napędnych & - & 2 osiowe/ 2 osiowe & 2 osiowe/ 2 osiowe & 2 osiowe/ 2 osiowe & 2 osiowe/ 2 osiowe \\
\hline Średnica kół tocznych / napędnych & $\mathrm{m}$ & $0,89 / 0,89$ & $0,92 / 0,92$ & $0,87 / 0,87$ & - \\
\hline Typ silnika spalinowego & - & MTU12V183TD12 & OM424A & OM444LA & - \\
\hline Moc silnika spalinowego & $\mathrm{kW}$ & 485 & 357 & 463 & $2 \times 228(2 \times 235)$ \\
\hline Rodzaj (typ) prądnicy & - & Synch. 1FC6 352-6 & Synch. Wgxy 315dw6 & Synch. Wgxy 315dw6 & Synch. Wgxy $315 w 6$ \\
\hline Moc prądnicy & $\mathrm{kW}$ & 485 & - & - & - \\
\hline Rodzaj silnika trakcyjnego & - & Asynch. BAZu5369/4 & Asynch. 6FKA3365 (AC) & 4ERG2040 (DC) & 4EKG2422 (DC) \\
\hline Moc silnika (silników) trakcyjnego & $\mathrm{kW}$ & - & - & - & - \\
\hline Rodzaj przekładni osiowej & - & - & - & - & - \\
\hline Producent & & AEG/MBB/Duewag/Fiat & Duewag/BBC & LHB/BBC & SGP \\
\hline
\end{tabular}

\section{PRZEGLĄD AUTOBUSÓW SZYNOWYCH Z NAPĘDEM SPALINOWO-ELEKTRYCZ- NYM}

Autobusy szynowe, coraz częściej wchodzące do eksploatacji na liniach drugorzędnych (obecnie również obsługują przewozy pasażerskie na liniach pierwszorzędnych - zwłaszcza autobusy z napędem elektrycznym), budowane są $\mathrm{z}$ różnymi układami napędowymi. Wśród producentów specjalizujących się $\mathrm{w}$ autobusach $\mathrm{z}$ napędem spalinowo-elektrycznym wymienić należy przede wszystkim firmy Stadler, Bombardier i Talbot.

Poniżej skrótowe opisy autobusów szynowych wypromowanych przez te firmy.

\section{a) Autobusy GTW 2/6 i GTW4/8 firmy Stadler}

Projekty i autobusy firmy Stadler są rozwinięciem konstrukcji pojazdów elektrycznych budowanych dla kolei prywatnych w Szwajcarii.

Autobusy budowane są w konfiguracji jako dwulub trzysekcyjne (człony pasażerskie) z jednym lub z dwoma członami napędowymi. Układ napędowy tworzą silnik spalinowy (silniki spalinowe) firm MTU lub MAN, prądnica (prądnice) synchroniczna, która za pośrednictwem zespołu prostowników i falowników (opartego o tyrystory GTO lub tranzystory IGTB) zasila trakcyjne silniki elektryczne prądu przemiennego [2]. 
Człony pasażerskie autobusów obu konfiguracji połączone są odpowiedniej długości modułem, w którym zabudowano zespół napędowy. Moduł ten oparty jest na dwuosiowym wózku napędowym. Człony pasażerskie (tylko końcowe) oparte są na dwuosiowych wózkach tocznych $\mathrm{z}$ jednej strony $\mathrm{i}$ wsparte są na przegubowym połączeniu $\mathrm{z}$ modułami napędowymi $\mathrm{z}$ drugiej strony. Oba rodzaje wózków (toczny i napędowy) mają nastawialne radialnie zestawy kołowe [22].

Autobusy GTW moga być budowane w trzech wersjach różniących się długością członów pasażerskich. Przewidziane są również cztery szerokości wagonów tzn. autobusy GTW są dostarczane dla czterech szerokości toru.

W ostatnim okresie firma Stadler $\mathrm{z}$ głównymi poddostawcami wyprodukowała kilka autobusów GTW o różnych rozwiązaniach konstrukcyjnych i różnych mocach.

Do najważniejszych z nich należą autobusy:

- dla Kolei Nadmorskiej Wyspy Uznam (propozycja wspólnej produkcji Stadlera i FPS H. Cegielski) z silnikiem MTU o mocy $550 \mathrm{~kW}$

- dla Regionalnych Kolei Brandenburgii o podobnej mocy i silniku jak wyżej
- dla Vinschgarbahn (Włochy) z wykorzysta-niem dwóch silników MAN o mocy $390 \mathrm{~kW}$ każdy

- dla Kolei Southern New Jersey USA z silnikiem MTU o mocy $550 \mathrm{~kW}$

- dla Krajowych Kolei Hessji z silnikiem MTU o mocy $550 \mathrm{~kW}$

- dla Krajowych Kolei Grecji o konfiguracji jak wyżej.

Wszystkie przedstawione autobusy składają się z dwóch członów pasażerskich i jednego członu napędowego, a ich główne parametry przedstawiono w tabeli 2.

Ogólny widok autobusów w wersji dwu- i trzyczłonowej przedstawiono na rys.4.

\section{b) Autobus Rebus firmy Adtranz dla Polskich Ko- lei Państwowych}

Regionalny autobus Rebus jest wspólnym dziełem firm grupy Adtranz oraz przedsiębiorstwa Stadler AG przy udziale konstruktorów z byłego Pafawagu Wrocław [7].

W projekcie uwzględniono najnowsze wymagania stawiane przez ówczesne PKP pojazdom do obsługi regionalnego ruchu kolejowego. Pierwowzorem dla tego autobusu był autobus GTW 2/6 firmy Stadler.

Ogólny widok autobusu przedstawiono na rys.5.

a)

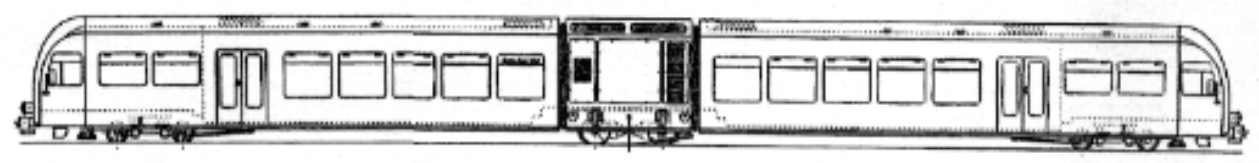

b)

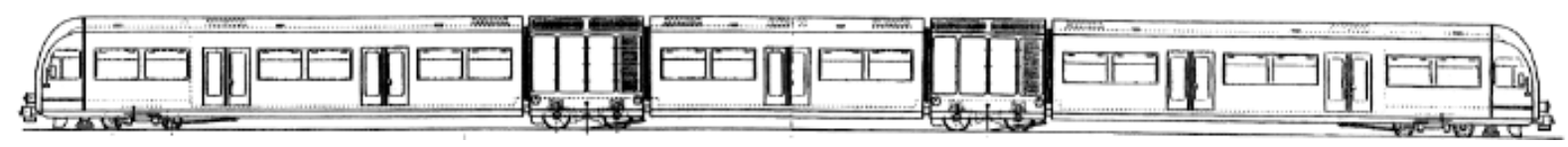

Rys.4. Ogólny widok autobusów firmy Stadler: a) GTW 2/6; b) GTW 4/8
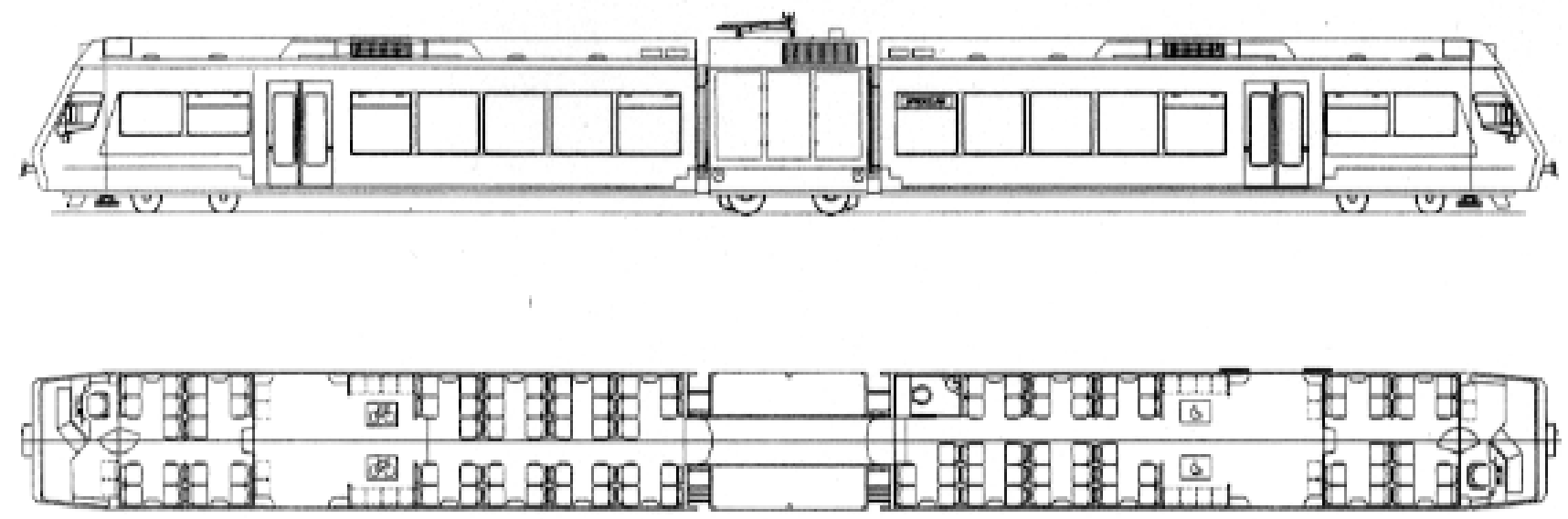

Rys.5. Ogólny widok autobusu Rebus w wersji podstawowej 
W wersji podstawowej Rebus jest pojazdem trójczłonowym, zestawionym $\mathrm{z}$ dwóch członów sterowniczych z miejscami dla pasażerów oraz środkowego napędowego. W trójczłonie zastosowano trzy dwuosiowe wózki, dwa toczne umieszczone pod członami sterowniczymi i napędowy pod członem napędowym. Zastosowane wózki zapewniają wysokie bezpieczeństwo jazdy oraz bardzo dobre własności dynamiczne, bardzo ważne w eksploatacji na torach o niskim standardzie utrzymania.

W wózku napędowym zamontowano poprzecznie dwa silniki trakcyjne (w pełni usprężynowane) $\mathrm{z}$ przekładniami zębatymi. Pudła wagonów sterowniczych dzięki zastosowanym profilom aluminiowym są lekkie i bardzo wytrzymałe.

Człon napędowy, usytuowany w środku autobusu w wersji podstawowej, jest konstrukcją stalowa. Znajdują się w nim dwa przedziały maszynowe oddzielone od siebie przejściem dla pasażerów.

W konstrukcji autobusu Rebus (również GTW) przyjęto zasadę unifikacji i modułowej budowy poszczególnych węzłów. Układ napędowy składający się z silnika spalinowego, prądnicy i silników trakcyjnych zostanie opisany w dalszej części.

Do zasilania napędów pomocniczych, w tym do zasilania trójfazowych silników, zastosowano przetwornicę statyczną w oparciu o elementy IGBT. Napędy pomocnicze mogą być zasilane również energia odzyskiwana przy hamowaniu elektrodynamicznym.

Autobus został wyposażony w hamulec elektrodynamiczny i elektropneumatyczny. Współdziałanie obu systemów hamulca odbywa się samoczynnie. Realizuje to system sterowania autobusu. Układ hamulcowy został wyposażony również w urządzenia antypoślizgowe.

Modułowa konstrukcja umożliwia budowę autobusu o większej pojemności, zestawionego z większej liczby członów. Możliwe wersje modułowe przedstawiono na rys. 6 .

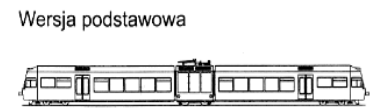

Wersja z 3 członami pasażerskimi i 1 napędowym

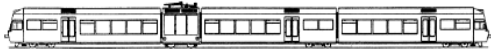

Wersja z 3 członami pasażerskimi i 2 napędowymi

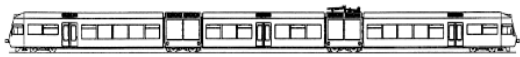

Wersja z 5 członami pasażerskimi i 2 napędowymi

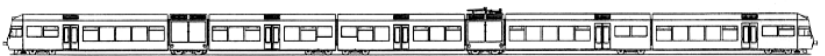

Rys.6. Wersje modułowe o różnej liczbie członów pasażerskich autobusów rodziny Rebus
Ponadto konstrukcja modułowa, jednakowy napęd oraz zgrupowanie wszystkich urządzeń zasilających i aparatury w członie napędowym umożliwiają szybką zamianę tego członu bez długotrwałego wyłączenia z eksploatacji całego pojazdu. Zaletą jest również to, że z jednego stanowiska sterowniczego można prowadzić pociag zestawiony $\mathrm{z}$ autobusów o różnych wersjach napędowych. Dzięki wyjątkowej lekkości autobus Rebus jest pojazdem o bardzo niskim zapotrzebowaniu na energię. Dodatkowym czynnikiem wpływającym na obniżenie kosztów energii jest jej odzysk w trakcie hamowania. Główne parametry autobusu Rebus w wersji podstawowej zaprezentowano w tabeli 2.

W wersji trójczłonowej autobusu zastosowano cztery wózki dwuosiowe: dwa lub trzy toczne, zabudowane pod członami sterowniczymi i dwa lub jeden silnikowy pod członem napędowym. Zastosowane wózki zapewniają bezpieczeństwo jazdy oraz dobre własności dynamiczne nawet na torowiskach o niskim standardzie utrzymania.

Mimo tak dużych zalet autobus Rebus nie wszedł do eksploatacji na Polskich Kolejach Państwowych, chociaż w kraju firma Stadler rozpoczęła uruchamianie swojej wytwórni.

\section{c) Autobusy VT644 (BR644) Talent firm Talbot i Elin}

Autobus, a w zasadzie rodzina autobusów Talent o różnej konfiguracji i różnych napędach, jest dziełem firm Talbot i Elin [5].

Pojazd $z$ napędem spalinowo-elektrycznym oparty jest na czterech wózkach dwuosiowych, z których skrajne są wózkami napędowymi, a środkowe (typu Jacobsa) wózkami tocznymi.

Ogólny widok autobusu wraz z rozmieszczeniem przedziałów pasażerskich przedstawiono na rys.7.

Pudła członów autobusu budowane są ze stali szlachetnej, konstrukcji aluminiowej (ściany boczne) i aluminiowej płyty warstwowej (dach) i moga przenosić siły wzdłużne o wartości $1500 \mathrm{kN}$. Opis układu napędowego podano $\mathrm{w}$ dalszej części.

Autobus jest wyposażony w hamulec elektrodynamiczny i hamulec pneumatyczny. Hamulcem mechanicznym zainstalowanym na wózkach jest hamulec typu tarczowego. Ponadto na wózkach napędowych zabudowane są hamulce magnetyczne [17].

Układy i urządzenia pomocnicze zasilane są $\mathrm{z}$ generatora pomocniczego o mocy $15,4 \mathrm{~kW}$ (przy 4500 $\mathrm{obr} / \mathrm{min}$ ) dającym napięcie $550 \mathrm{~V}$, przekształconym następnie na napięcie $24 \mathrm{~V}$ prądu stałego. Silnik spalinowy i układ napędowy oraz cały autobus wyposażony jest w 32 bitowy układ sterowania mikroprocesorowego Eltas [19, 27].

W każdym członie znajdują się dwie szafy z bateriami $24 \mathrm{~V}$ o pojemnościach: główna $225 \mathrm{Ah}$ i rozruchowa 55Ah. Dotychczas firma Talbot wyprodukowała około 60 autobusów VT644 (BR644). 

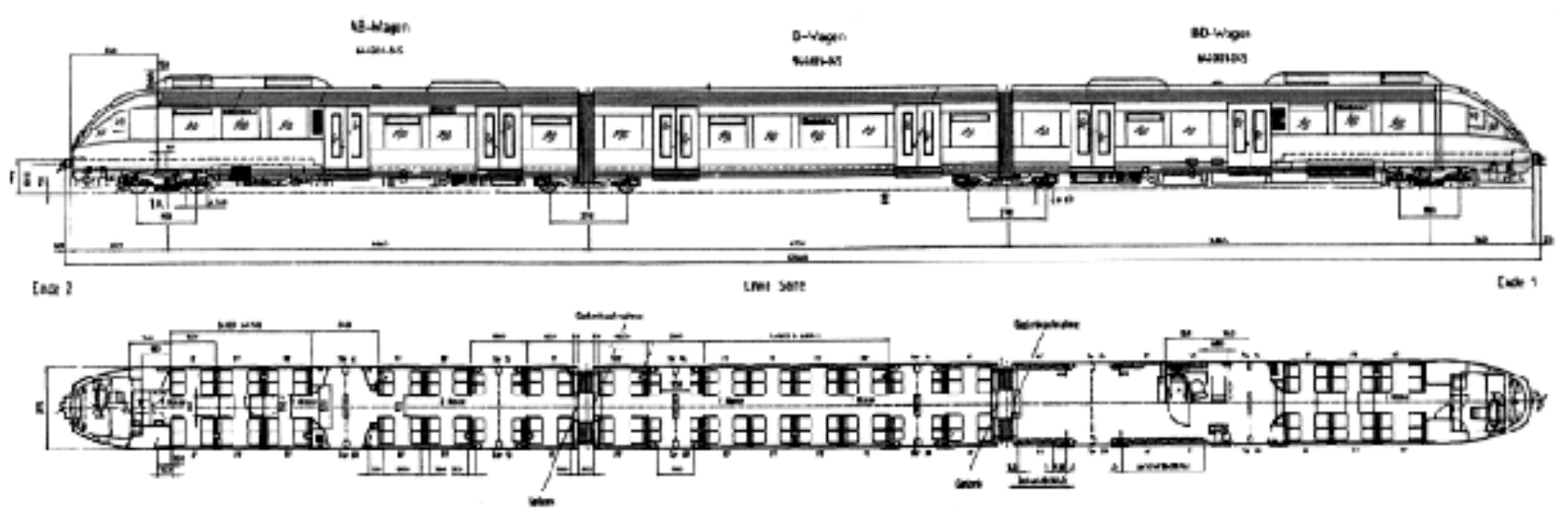

Rys.7. Ogólny widok autobusu VT644 (BR644) Talent

\section{d) Autobusy DMU i EDMU firmy Bombardier}

Najnowszą generacją autobusów firmy Bombardier są autobusy AGC DMU i EDMU z napędem spalinowo-elektrycznym oraz EMU $\mathrm{z}$ napędem elektrycznym z sieci $1,5 \mathrm{kV}$ DC i $25 \mathrm{kV} 50 \mathrm{~Hz}$ AC. Oba rodzaje autobusu zostały zamówione przez SNCF (Francja) do obsługi regionalnych kolei ekspresowych.

Autobusy DMU i EDMU budowane sa jako pojazdy dwu- trzy - i czteroczłonowe i cechują się opływowymi kształtami ze względu na rozwijane duże prędkości eksploatacyjne tj. 140 $\div 160 \mathrm{~km} / \mathrm{h}$ [18].

Pudła oparte są na wózkach dwuosiowych, przy czym człony napędowe posiadają w przednich częściach wózki silnikowe, a na wózkach tocznych oparte są człony sąsiadujące (napędowy z tocznym lub oba toczne). Są to wózki typu Jacobs o podobnej budowie jak w pojazdach z rodziny Talent.
Zespół napędowy został opracowany w oparciu o silnik (silniki) spalinowy firmy MAN, przy czym w autobusie dwuczłonowym zastosowano jeden silnik, a w autobusach trzy- i czteroczłonowych dwa silniki. Autobusy charakteryzują się małymi naciskami zestawu kołowego na tor (nie przekraczają $17 \mathrm{t}$ ) i dużym udziałem (do 80\%) niskiej podłogi, między innymi dzięki zastosowaniu kół o średnicy $840 \mathrm{~mm}$ [18].

W autobusach zastosowano hamulec elektrodynamiczny i hamulec pneumatyczny. Sterowanie zespołem napędowym, hamulcami i całym autobusem zapewnia mikroprocesorowy system MATRICS. Ponadto autobusy posiadają pełną diagnostykę głównych zespołów i urządzeń.

Główne parametry autobusów szynowych przedstawiono w tabeli 2.

Autobusy szynowe

spalinowo-elektrycznym ukladem napęowym

\begin{tabular}{|c|c|c|c|c|}
\hline $\begin{array}{|rr|}\text { Parametr } & \text { Seria (typ) pojazdu } \\
\text { Kraj }\end{array}$ & \begin{tabular}{|c|} 
Jedno \\
stka \\
miary \\
\end{tabular} & $\begin{array}{l}\text { GTW 2/6 } \\
\text { Niemcy }\end{array}$ & $\begin{array}{l}\text { VT } 644 \text { BR644) } \\
\text { Niemcy }\end{array}$ & $\underset{\text { Niemcy }}{\text { GTW } 4}$ \\
\hline Układ osi & - & $2 \mathrm{~B}_{0} 2^{\prime}$ & $\mathrm{B}^{\prime} 2 \mathrm{2}^{\prime} \mathrm{B}^{\prime}$ & $2 \mathrm{~B}_{0} \mathrm{~B}_{0} 2$ \\
\hline Masa własna / napędna & $\mathrm{Mg}$ & $42 /-$ & $87 /-$ & $75 /-$ \\
\hline $\begin{array}{l}\text { Nacisk zestawu kołowego na tor } \\
\text { (toczny / napędny) }\end{array}$ & $\mathrm{kN}$ & 157 & - & 176,6 \\
\hline Prędkość & $\mathrm{km} / \mathrm{h}$ & 120 & 120 & 120 \\
\hline Długość całkowita pojazdu & $\mathrm{m}$ & 37,14 & 51,92 & 51,02 \\
\hline $\begin{array}{l}\text { Liczba miejsc siedzących / stojących / } \\
\text { całkowita }\end{array}$ & - & $104(142) / 136(98) / 204(230)$ & $161 / 150 / 311$ & $198 / 190 / 388$ \\
\hline Rodzaj wózków tocznych / napędnych & - & 2 osiowe/ 2 osiowe & 2 osiowe/ 2 osiowe & 2 osiowe/ 2 osiowe \\
\hline Średnica kół tocznych / napędnych & m & $0,86 / 0,68$ & $0,76 / 0,63$ & $0,86 / 0,68$ \\
\hline Typ silnika spalinowego & - & MTU12V183TD13 & MTU12V183TD13 & MTU12V183TD13 \\
\hline Moc silnika spalinowego & $\mathrm{kW}$ & 540 & $2 \times 505$ & $2 \times 540$ \\
\hline Rodzaj (typ) prądnicy & - & Synchron. & Synch. Firmy Elin. & Synchron. \\
\hline Moc prądnicy & kW & - & - & - \\
\hline Rodzaj silnika trakcyjnego & - & Asynch. & Asynch. & Asynch. \\
\hline Moc silnika (silników) trakcyjnego & $\mathrm{kW}$ & $222(444)$ & 305 & 260 \\
\hline Rodzaj przekładni osiowej & - & - & - & - \\
\hline Producent & & Stadler, DWA, SLM, AEG & Talbot, Elin & $\begin{array}{l}\text { Adtranz, DWA, } \\
\text { SLM, Stadler }\end{array}$ \\
\hline
\end{tabular}


Autobusy szynowe

ze spalinowo-elektrycznym układem napẹdowym

Tabela 2 c.d.

\begin{tabular}{|c|c|c|c|c|c|}
\hline 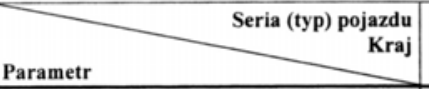 & $\begin{array}{c}\text { Jednost } \\
\text { ka } \\
\text { miary }\end{array}$ & $\begin{array}{l}\text { Rebus } \\
\text { Polska }\end{array}$ & $\begin{array}{c}\text { GTW DMU-2 2/6 } \\
\text { Wlochy }\end{array}$ & $\begin{array}{l}\text { GTW 2/6 } \\
\text { New Jersey }\end{array}$ & $\begin{array}{c}\text { GTW 2/6 } \\
\text { Grecja }\end{array}$ \\
\hline Układ osi & - & $2 \mathrm{~B}_{0} 2^{\prime}$ & $2 \mathrm{~B}_{0}^{\prime} 2^{\prime}$ & $2 \mathrm{~B}_{0}^{\prime} 2^{\prime}$ & $2 \mathrm{~B}_{0}^{\prime} 2^{\prime}$ \\
\hline Masa własna / napędna & $\mathrm{Mg}$ & 50,3 & 66 & 54,8 & 57 \\
\hline $\begin{array}{l}\text { Nacisk zestawu kołowego na tor } \\
\text { (toczny / napędny) }\end{array}$ & $\mathrm{kN}$ & - & - & - & - \\
\hline Prędkość & $\mathrm{km} / \mathrm{h}$ & 120 & 140 & 110 & 115 \\
\hline Dhugość całkowita pojazdu & $\mathrm{m}$ & 38,03 & 39,5 & 31,242 & 35,189 \\
\hline $\begin{array}{l}\text { Liczba miejsc siedzących / stojących / } \\
\text { całkowita }\end{array}$ & - & $108 / 148 / 256$ & $104 / 110 / 214$ & $90 / 94 / 184$ & $94 / 106 / 200$ \\
\hline Rodzaj wózków tocznych / napędnych & - & 2 osiowe/ 2 osiowe & 2 osiowe/ 2 osiowe & 2 osiowe/ 2 osiowe & 2 osiowe/ 2 osiowe \\
\hline Średnica kół tocznych / napędnych & $\mathrm{m}$ & - & $0,86 / 0,75$ & $0,86 / 0,68$ & $0,86 / 0,75$ \\
\hline Typ silnika spalinowego & - & - & MAN & MTU & MTU \\
\hline Moc silnika spalinowego & $\mathrm{kW}$ & 430 & $2 \times 390$ & 550 & 550 \\
\hline Rodzaj (typ) prądnicy & - & Synchron. & Synchron. & Synchron. & Synchron. \\
\hline Moc prądnicy & $\mathrm{kW}$ & - & - & - & - \\
\hline Rodzaj silnika trakcyjnego & - & Asynch. & Asynch. & Asynch. & Asynch. \\
\hline Moc silnika (silników) trakcyjnego & $\mathrm{kW}$ & - & - & - & - \\
\hline Rodzaj przekładni osiowej & - & - & - & - & - \\
\hline Producent & & A Dtranz & Stadler & Bombardier - Stadler & Stadler \\
\hline
\end{tabular}

Autobusy szynowe

ze spalinowo-elektrycznym układem napędowym

Tabela 2 c.d.

\begin{tabular}{|c|c|c|c|c|}
\hline \begin{tabular}{|r|r|} 
Seria (typ) pojazdu \\
Kraj \\
\end{tabular} & \begin{tabular}{c|}
$\begin{array}{c}\text { Jednost- } \\
\text { ka } \\
\text { miary }\end{array}$ \\
\end{tabular} & $\begin{array}{c}\text { DMU } \\
\text { Francja }\end{array}$ & $\begin{array}{c}\text { DMU/EDMU } \\
\text { Francja }\end{array}$ & $\begin{array}{c}\text { DMU/EDMU } \\
\text { Francja }\end{array}$ \\
\hline Układ osi & - & $\mathrm{B}_{0}^{\prime} 2^{\prime} 2^{\prime}$ & $\mathrm{B}_{0}^{\prime} 2 \mathrm{~B}_{0}^{\prime}$ & $\mathrm{B}_{0}^{\prime} 2^{\prime} 22^{\prime} \mathrm{B}_{0}^{\prime}$ \\
\hline Masa własna / napędna & $\mathrm{Mg}$ & 95,3 & $133,3(134,9)$ & $161,2 / 163,2$ \\
\hline $\begin{array}{l}\text { Nacisk zestawu kołowego na tor } \\
\text { (toczny / napędny) }\end{array}$ & $\mathrm{kN}$ & 166,8 & 168,8 & 168,8 \\
\hline Prędkość & $\mathrm{km} / \mathrm{h}$ & 140 & 160 & 160 \\
\hline Dhugość całkowita pojazdu & $\mathrm{m}$ & 42,00 & 57,40 & 72,80 \\
\hline $\begin{array}{l}\text { Liczba miejsc siedzących / stojących / } \\
\text { całkowita }\end{array}$ & - & $112 /-/-$ & $166 /-/-$ & 220/-/- \\
\hline Rodzaj wózków tocznych / napędnych & - & 2 osiowe/ 2 osiowe & 2 osiowe/ 2 osiowe & 2 osiowe/ 2 osiowe \\
\hline Średnica kół tocznych / napędnych & $\mathrm{mm}$ & 840 & 840 & 840 \\
\hline Typ silnika spalinowego & - & MAN D2842LE606 & MAN D2842LE606 & MAN D2842LE606 \\
\hline Moc silnika spalinowego & $\mathrm{kW}$ & 662 & $2 \times 662$ & $2 \times 662$ \\
\hline Rodzaj (typ) prądnicy & - & Synchron. & Synchron. & Synchron. \\
\hline Moc prądnicy & $\mathrm{kW}$ & - & - & - \\
\hline Rodzaj silnika trakcyjnego & - & Asynchron. & Asynchron. & Asynchron. \\
\hline Moc silnika (silników) trakcyjnego & $\mathrm{kW}$ & 325 & 325 & 325 \\
\hline Rodzaj przekładni osiowej & - & - & - & - \\
\hline Producent & & Bombardier & Bombardier & Bombardier \\
\hline
\end{tabular}

5. ROZWIAZZANIA KONSTRUKCYJNE NAPĘDÓW SPALINOWO-ELEKTRYCZNYCH

Ogólnie napędem określa się zespół urządzeń, maszyn i aparatów służących do przeniesienia momentu obrotowego wytwarzanego przez silnik spalinowy na zestaw (zestawy) kołowy pojazdu szynowego.
W skład napędu spalinowo-elektrycznego wchodzą następujące główne urządzenia: silnik (silniki) spalinowy (leżący lub stojący), prądnica prądu stałego lub synchroniczna, zespół prostownikowy lub prostownikowo-falownikowy, silnik (silniki) trakcyjny prądu stałego lub asynchroniczny, przekładnia osiowa oraz dodatkowo wały przegubowe, wały drążone, sprzegła itd. 
Napędy spalinowo-elektryczne można dzielić ze względu na zabudowę, rodzaj wózków, zastosowane maszyny elektryczne, rodzaj przekładni oraz sposób zawieszenia (mocowania) przekładni i silnika (silników) trakcyjnego [4].

W dalszej części będzie omówienie wybranych rozwiązań, zastosowanych $\mathrm{w}$ spalinowych zespołach trakcyjnych oraz autobusach szynowych.

\subsection{Przykładowe rozwiązania napędów spalino- wych zespolów trakcyjnych}

\section{a) Napęd spalinowego zespołu serii VT 610}

Zespół VT 610 napędzany jest układem spalinowo-elektrycznym składającym się $\mathrm{z}$ dwóch silników MTU 12V183TD o mocy $485 \mathrm{~kW}$ każdy, dwóch prądnic synchronicznych, dwóch prostowników, falownika (przekształtnika) zbudowanego na tyrystorach GTO oraz trzech asynchronicznych silników trakcyjnych.

Całość napędu zabudowana jest pod ostoją wagonu. Silniki spalinowe są doładowywane schłodzonym powietrzem. Wentylatory dla wody chłodzącej oraz chłodnicy powietrza doładowującego są napędzane hydrostatycznie, przy czym pompa hydrostatyczna jest połączona $\mathrm{z}$ wolnym końcem prądnicy głównej. Silniki trakcyjne przenoszą moment obrotowy na zestaw kołowy poprzez wał przegubowy i przekładnię osiową [9].

Schemat obwodu głównego zespołu przedstawiono na rys.8.

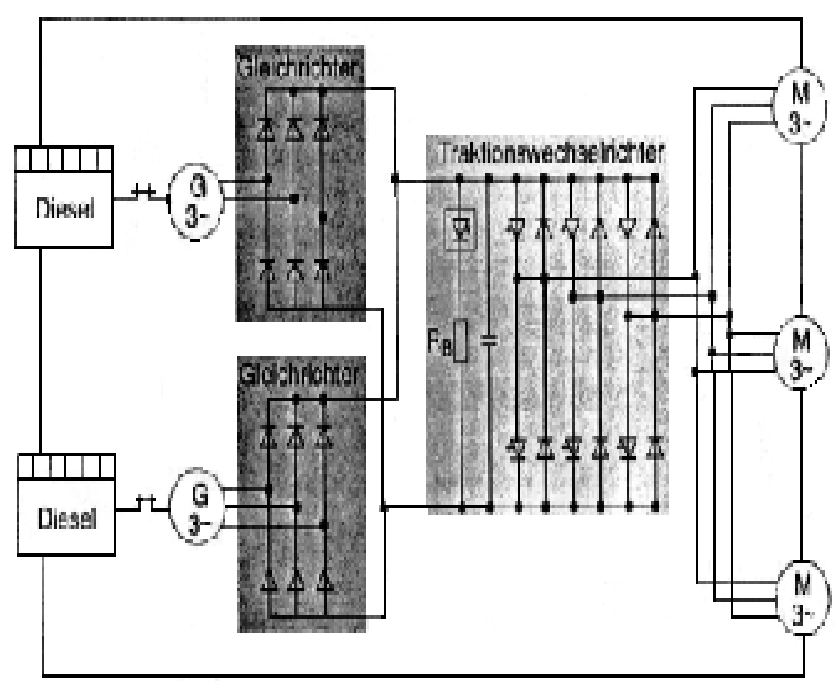

Rys.8. Połączenia obwodu głównego zespołu VT610[9]: Diesel - silnik spalinowy; $\mathrm{G}$ - prądnica główna; Gleichrichter - prostownik; $\mathrm{M}$ - silnik trakcyjny; Traktionswechselrichter - przekształtnik trakcyjny; $\mathrm{R}_{\mathrm{B}}$ - opornik hamowania
W układzie napędowym silniki trakcyjne asynchroniczne zasilane są z przekształtnika trakcyjnego ze zmienną częstotliwością i napięciem. Napędy układu chłodzenia silników trakcyjnych, układu przechyłu pudeł oraz wszystkie odbiorniki pomocnicze są zasilane elektrycznie.

Zasilanie napędów pomocniczych i innych aparatów oraz urządzeń pomocniczych odbywa się napięciem $400 \mathrm{~V} 50 \mathrm{~Hz}, 230 \mathrm{~V} 50 \mathrm{~Hz}$ oraz $24 \mathrm{~V}$ DC. System sterowania całego pojazdu V610 jest oparty na technice mikroprocesorowej. Jest to automatyczny system pociagowy SIBAS 16.

\section{b) Napęd spalinowego zespołu serii BM/BS92}

Wagon zespołu jest napędzany dwoma dwunastocylindrowymi silnikami spalinowymi, chłodzonymi wodą i doładowywanymi z wykorzystaniem turboładowarek napędzanych spalinami, o mocy $357 \mathrm{~kW}$ każdy. Z silnikiem połączona jest kołnierzowo jednołożyskowa prą̨nica główna, przekazująca energię elektryczną poprzez prostownik i przekształtnik pulsacyjny na oba wózki napędowe, na których znajduja się asynchroniczne silniki trakcyjne [14].

Silnik spalinowy, prądnica główna i prądnica pomocnicza są zabudowane pod pudłem na wspólnej ramie. Rama jest mocowana w trzech punktach, $\mathrm{z}$ czego dwa znajdują się na belce wzdłużnej, natomiast trzeci znajduje się na trawersie mocowanej do belki wzdłużnej. Elementy mocujące są elastyczne, izolujące ramę nadwozia od drgań agregatu prądotwórczego [8].

Również prą̨nica pomocnicza jest zawieszona elastycznie pod pudłem wagonu. Zgrupowanie (koncentracja) urządzeń układu napędowego oraz ich krótkie połączenia dają wysokie wartości masy przyczepnej napędowych zestawów kołowych. Rozmieszczenie wszystkich urządzeń i zespołów pod pudłem wagonu przedstawiono na rys.9.

Obwód główny napędu, hamowania elektrodynamicznego i zasilania pociagu przedstawiono na rys. 10 .

Napęd przekazywany jest na silniki trakcyjne (zawieszone elastycznie na ramie wózka napędowego) za pośrednictwem wału przegubowego, sprzęgieł typu Secheron oraz przekładni osiowej.

Wszystkie urządzenia i napedy pomocnicze zasilane sa napięciem 3x220V AC i 3x36V AC, a system sterowania $\mathrm{i}$ diagnostyki zespołu to znany mikroprocesorowy automatyczny system MICAS, zabezpieczający niezawodne działanie zespołu napędowego oraz diagnozujący stan pracy jego głównych urządzeń i układów. 


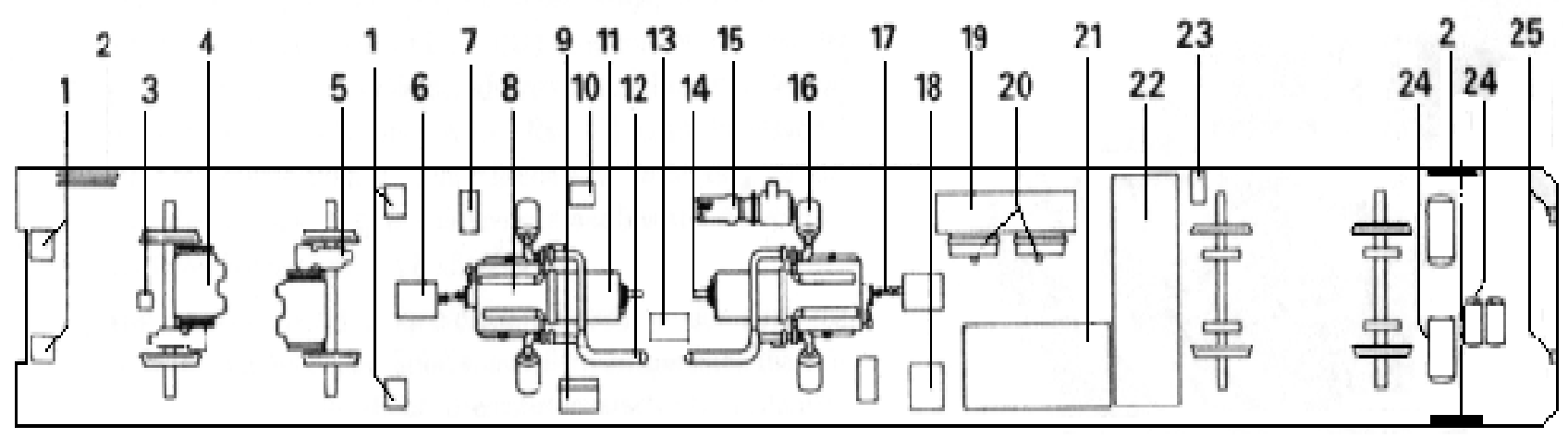

Rys.9. Rozmieszczenie urządzeń i zespołów układu maszynowego zespołu BM/BS92

1 - urządzenia piaskowania; 2 - podgrzewacze stopni wejściowych; 3 - dławik wstępny; 4 - silnik trakcyjny; 5 - przekładnia osiowa; 6 - prądnica pomocnicza; 7 - podgrzewacz wstępny; 8 - silnik spalinowy; 9 - transformator; 10 - wentylator silnika spalinowego; 11 - prądnica główna; 12 - układ wylotu spalin; 13 - zbiornik oleju hydrostatycznego; 14 - pompa chłodnicy; 15 - sprężarka; 16 - zasilanie powietrzem do spalania; 17 - wał przegubowy; 18 - skrzynia urządzeń elektrycznych; 19 - układ chłodzenia; 20 - silnik chłodnicy; 21 - skrzynia baterii akumulatorów; 22 - zbiornik paliwa; 23 -gniazdo z napięciem 220V; 24 - zbiornik powietrza; 25 - gniazdo połączeniowe $1000 \mathrm{~V}$ dla ogrzewania pociagu.

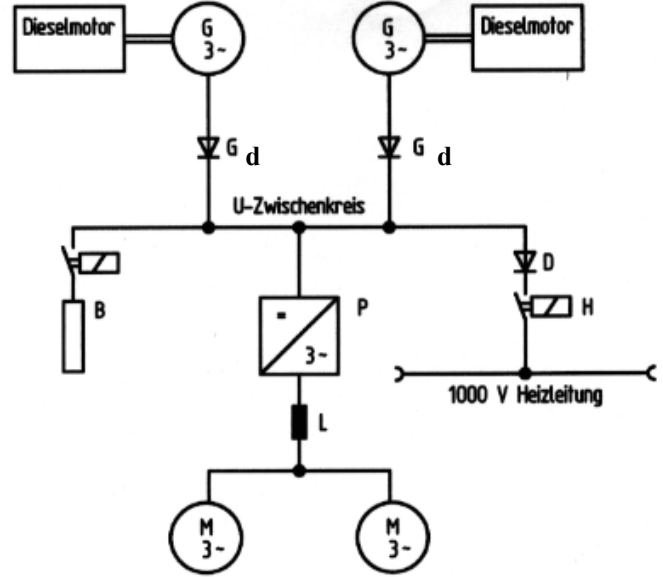

Rys.10. Obwód główny zespołu BM/BS92 [8]

B - opornik hamulca z zabezpieczeniem; D - dioda; $\mathrm{G}_{\mathrm{p}}-$ główny prostownik; $\mathrm{H}$ - ogrzewanie; $\mathrm{L}$ - dławik wstępny silników trakcyjnych; $\mathrm{M}$ - silnik trakcyjny; $\mathrm{P}$ - przekształtnik pulsacyjny; $\mathrm{U}$ - obwód pośredni; G - prądnica główna.

\section{c) Napęd spalinowego zespołu trakcyjnego serii VT/VS 2E}

Napęd zespołu składa się z dwunastocylindrowego silnika spalinowego OM444LA z doładowaniem o mocy $463 \mathrm{~kW}$ (przy $2100 \mathrm{obr} / \mathrm{min}$ ), prądnicy głównej, prostownika i połączonych $\mathrm{w}$ dwóch równoległych grupach czterech silników trakcyjnych prądu stałego [3].

Obwód główny zespołu przedstawiono na rys.11, a rozmieszczenie maszyn i urządzeń pod pudłem obu członów zespołu na rys.12.

Podobny układ napędowy został zastosowany w zespole VT70, przy czym do napędu wykorzystano dwa silniki spalinowe o mocy $228 \mathrm{~kW}$ lub $235 \mathrm{~kW}$ każdy.

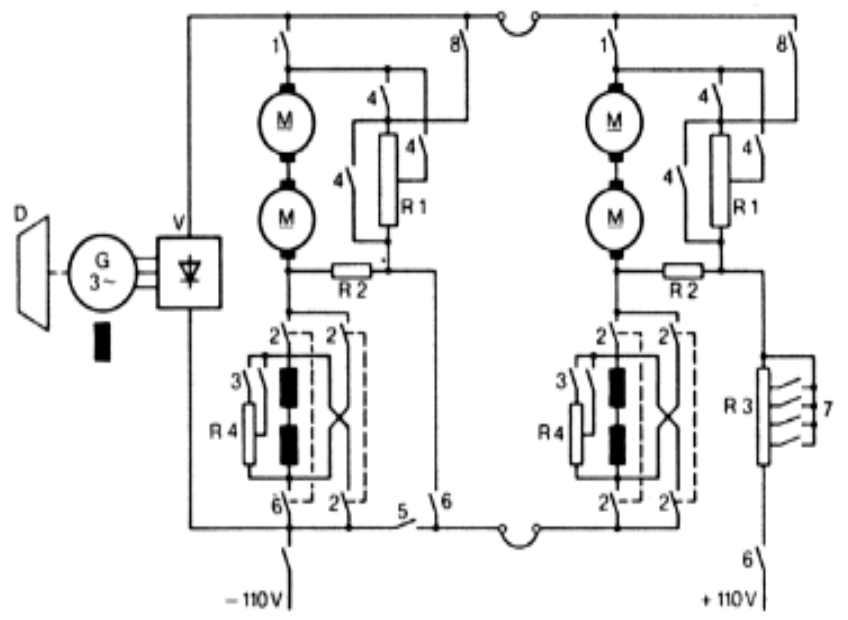

D - silnik spalinowy;

$\mathrm{G}$ - prądnica;

$\mathrm{V}$ - prostownik;

$\mathrm{M}$ - silnik trakcyjny;

R1 - opornik hamulca;

R2 - opornik bocznikowy;

R3 - opornik regulacyjny hamulca;

R4 - mostek;

1 - stycznik jazdy;

2 - stycznik liniowy;

3 - stycznik osłabienia pola;

4 - stycznik hamulca;

5 - stycznik grupowy;

6 - stycznik regulacji hamulca;

7 - stycznik regulacji poziomu załadowania;

8 - stycznik ogrzewania.

Rys.11. Obwód główny zespołu VT/VS2E [3] 


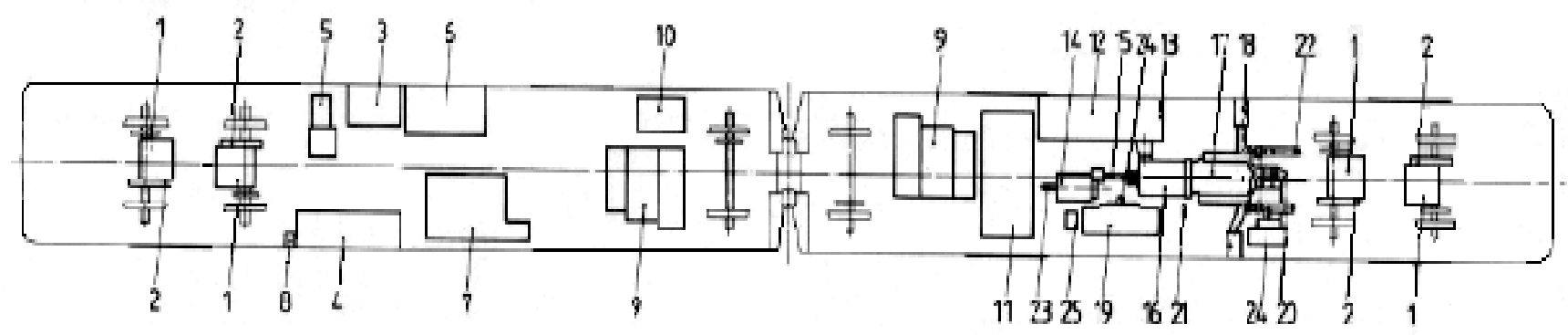

Rys.12. Rozmieszczenie maszyn i urządzeń w członach zespołu trakcyjnego VT/VS2E

1 - silnik trakcyjny; 2 - przekładnia osiowa; 3,4 - skrzynie baterii akumulatorów; 5 - sprężarka główna; 6 - skrzynia urządzeń elektrycznych; 7 - układ sprężonego powietrza; 8 - sieć zewnętrzna - gniazdo zasilania; 9 - agregat opornika; 10 - smarowanie obrzeży kół; 11 - zbiornik paliwa; 12 - skrzynia urządzeń elektrycznych; 13 - prostownik; 14 prądnica pomocnicza; 15 - wał drążony; 16 - prądnica; 17 - silnik spalinowy; 18 - zasilanie powietrzem, 19 chłodnica wody; 20 - chłodnica powietrza doładowania; 21 - podgrzewacz; 22 - układ wylotu spalin; 23 - wentylator; 24 - silnik wentylatora; 25 - zbiornik oleju hydraulicznego.

\subsection{Przykładowe rozwiązania napędów autobusów szynowych}

a) Napęd autobusu szynowego VT644 (BR644)

Układ napędowy autobusu składa się z dwunastocylindrowego silnika firmy MTU połączonego $\mathrm{z}$ prądnicą synchroniczną firmy Elin. Oba urządzenia mocowane są za pośrednictwem czterech gumowych amortyzatorów wraz $\mathrm{z}$ innymi elementami napędowymi. Wylot spalin z thumikiem ustawionym poziomo jest mocowany do pionowego wspornika i wyprowadzony na dach. Wentylatory chłodnic są napędzane hydrostatycznie. Rama jest mocowana do pudła wagonu skrajnego za pośrednictwem sworzni i śrub.

Po przeciwnej stronie prądnicy ponad ramą znajdują się napędy: sprężarki hamulcowej, pompy hydrostatycznej układu chłodzenia i sprężarki klimatyzato$\mathrm{ra}$, a na drugiej stronie znajduje się prądnica pomocnicza o mocy $15,4 \mathrm{~kW}$ przy $45001 / \mathrm{min}$ i napięciu $550 \mathrm{~V}$, które zostaje przetworzone na napięcie $24 \mathrm{~V}$ DC. Prądnica pomocnicza zabezpiecza i zasila wszystkie urządzenia pomocnicze [5].

Prądnica główna z przewietrzaniem własnym wytwarza prąd przemienny, który następnie jest wyprostowany i przekształcony w przekształtniku zbudowanym na tranzystorach IGBT, zasilając silnik trakcyjny asynchroniczny o mocy $305 \mathrm{~kW}$.

Przekształtnik jest chłodzony powietrzem zewnętrznym, natomiast silnik asynchroniczny zawieszony pod kabiną sterownicza, chłodzony woda, napędza pierwszą oś poprzez wał drążony.

Oporniki hamulca chłodzone są strumieniem powietrza podczas jazdy i znajdują się wraz z przekształtnikiem i regulatorem hamulca na dachu.

Obwód główny autobusu przedstawiono na

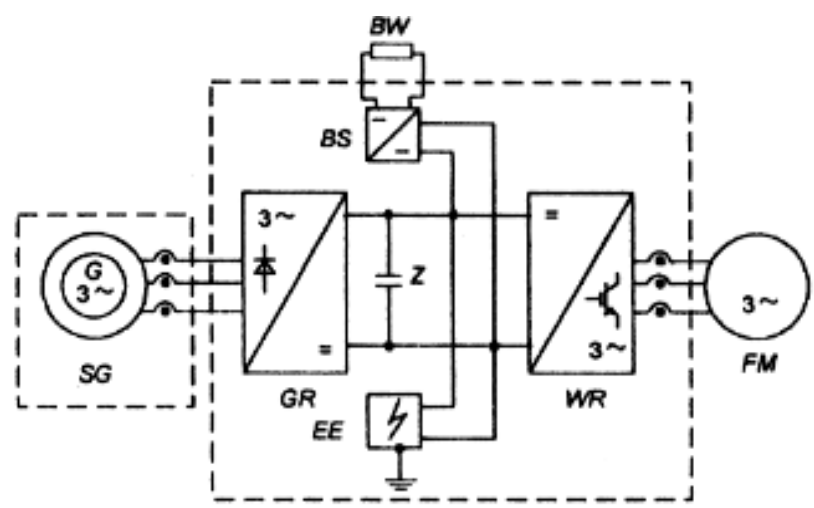

Rys.13. Obwód główny napędu autobusu VT644 (BR644) SG - prądnica synchroniczna; GR - prostownik; BW opornik hamulca; BS - regulator hamulca; EE - uziemienie; WR - przekształtnik; FM - silnik trakcyjny.

Cały napęd jest sterowany systemem mikroprocesorowym Eltas-32. Każdy człon wyposażony jest w dwie skrzynie (mocowane pod podłogą członu) z bateriami akumulatorowymi o pojemnościach 225 i $55 \mathrm{Ah}$.

\section{b) Napęd autobusu szynowego GTW $2 / 6$ i GTW $4 / 8$}

Autobusy GTW posiadaja specjalne (jeden lub dwa) człony napędowe, w których jest zabudowany cały napęd.

Jako silnik napędowy zastosowano w nim dwunastocylindrowy silnik spalinowy 12V183TD13 firmy MTU o mocy $540 \mathrm{~kW}$ przy $2100 \mathrm{obr} / \mathrm{min}$. Z silnikiem połączona jest bezpośrednio bezszczotkowa prądnica synchroniczna za pomocą kołnierza SAE1. rys. 13 . 
Prąd przemienny prądnicy zasila poprzez niesterowany mostek prostowniczy obwód pośredni. Przeniesienie mocy na obydwa napedowe zestawy kołowe odbywa się poprzez przekształtnik $\mathrm{z}$ tranzystorami IGBT.

Zestawy napędzane są silnikami asynchronicznymi. Chłodzenie powietrza doładowania i chłodzenie wodne zapewniają układy chłodzące $\mathrm{z}$ wentylatorami napędzanymi hydrostatycznie.

Dostęp do zabudowanych urządzeń odbywa się przez klapy, znajdujące się na każdej ścianie bocznej zewnętrznej oraz od przejścia wewnętrznego. Autobusy oprócz hamulca pneumatycznego (hamulcem mechanicznym jest hamulec tarczowy) posiadają hamulec elektrodynamiczny. System silniki trakcyjne przekształtnik - oporniki hamulcowe zapewnia działanie od prędkości maksymalnej aż do zatrzymania ze stałą siłą hamowania. Napędy pomocnicze zasilane są $\mathrm{z}$ prądnicy pomocniczej lub baterii o napięciu $24 \mathrm{~V}$, ładowanych alternatorem zabudowanym na silniku spalinowym [22].

Rozmieszczenie urządzeń i zespołów w członie napędowym przedstawiono na rys. $14 \div 16$.

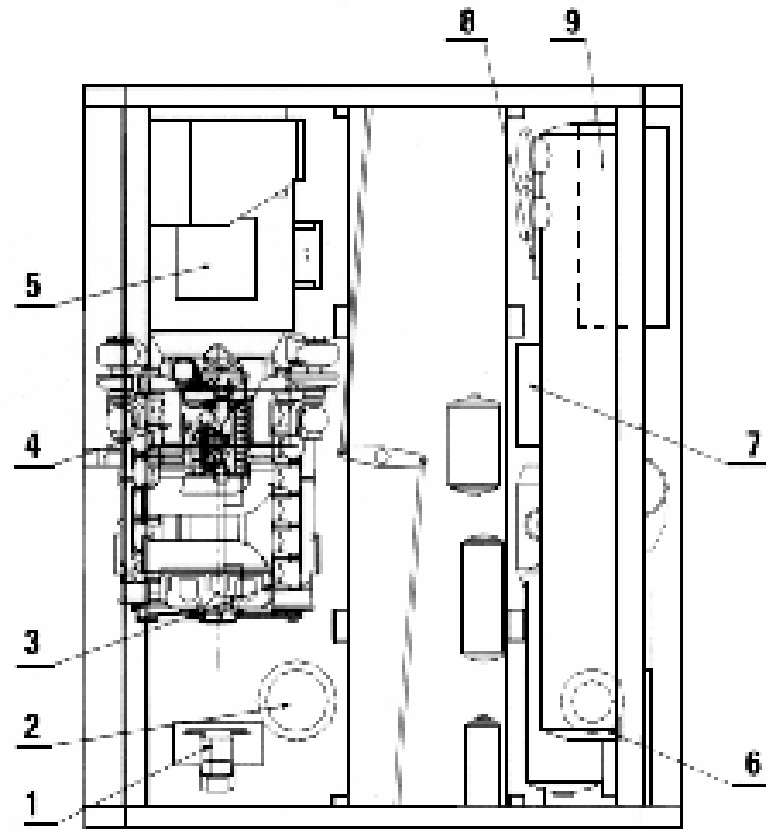

Rys.14. Rozmieszczenie urządzeń i zespołów autobusu widok $\mathrm{z}$ góry

1-pompa hydrostatyczna; 2-podgrzewacz; 3 - silnik spalinowy; 4 - zbiornik wyrównawczy wody; 5 - prądnica; 6 tłumik wylotu spalin; 7- urządzenie sterowania pojazdem; 8-układ sterowania; 9 - przekształtnik pulsacyjny.

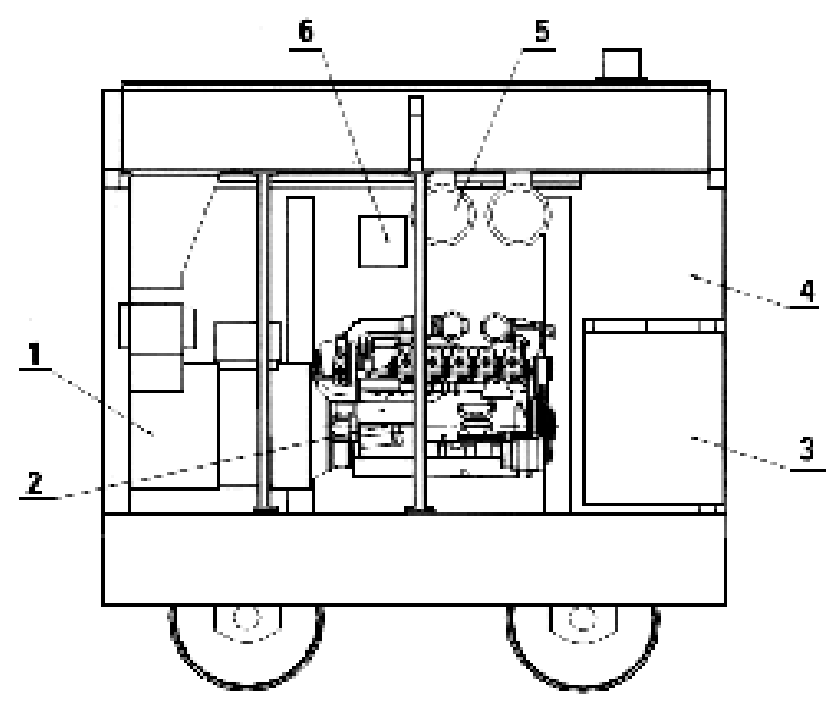

Rys.15. Rozmieszczenie urządzeń i zespołów autobusu widok $\mathrm{z}$ boku

1 - prądnica; 2 - silnik spalinowy; 3 - chłodnica wodna; 4 - chłodnica powietrza doładowanego; 5 - wentylator; 6 zbiornik wyrównawczy wody chłodzącej.

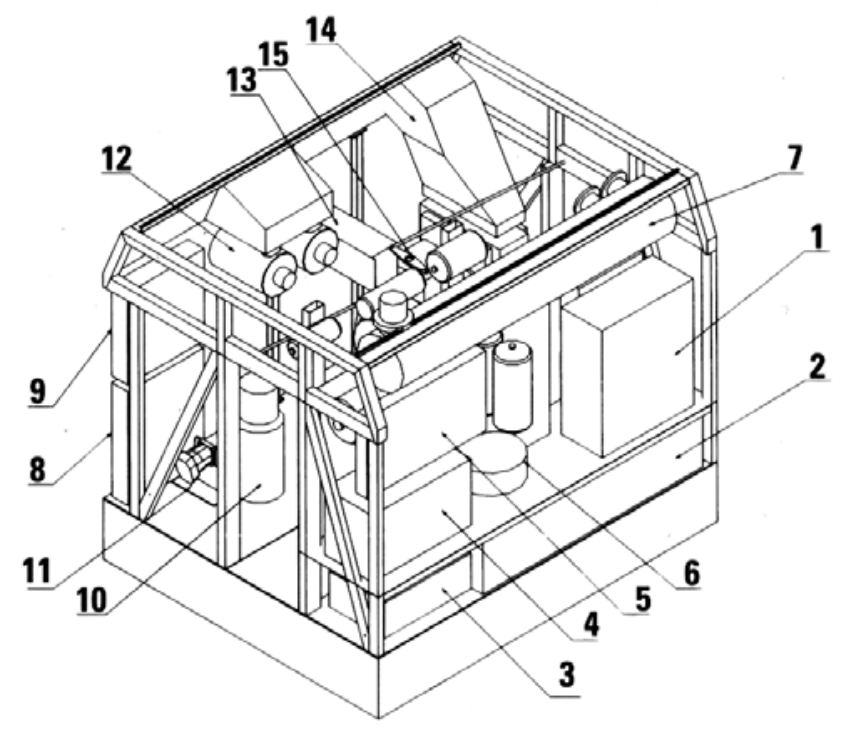

Rys.16. Rozmieszczenie przestrzenne urządzeń i zespołów autobusu GTW2/6 i GTW4/8

1 - przekształtnik pulsacyjny; 2 - zbiornik paliwa; 3 baterie; 4 -zespół przygotowania powietrza; 5 - tablica hamulcowa; 6 - układ wzbudzenia silników trakcyjnych; 7 - tłumik wylotu spalin; 8 - chłodnica wodna; 9 - chłodnica powietrza doładowanego; 10 - kocioł grzewczy; 11 pompa hydrostatyczna; 12 - filtr powietrza; 13 - zbiornik wyrównawczy wody chłodzącej; 14 - wloty powietrza; 15 - łącznik skrętny. 


\section{c) Napęd autobusu szynowego Rebus}

W autobusie Rebus zastosowano generator synchroniczny napędzany wysokoprężnym silnikiem spalinowym firmy MTU rodziny 183 , z wtryskiem bezpośrednim, chłodzonym wodą. Silnik napędza prądnicę synchroniczna, pracując $\mathrm{z}$ optymalną prędkością obrotową $\mathrm{w}$ zależności od zapotrzebowania mocy zespołu trakcyjnego.

Prędkość obrotowa silnika spalinowego jest regulowana. Dokładna regulacja odbywa się za pomocą uzwojenia wzbudzenia bezszczotkowej prądnicy synchronicznej. Silnik charakteryzuje się nie tylko niskim zużyciem paliwa i oleju, ale spełnia również europejskie normy czystości spalin Euro II [7].

Wytwarzane przez prądnicę napięcie przemienne jest prostowane do $1500 \mathrm{~V}$ i doprowadzane do obwodu pośredniego przekształtnika jako napięcie wyjściowe. Przekształtnik zbudowany z elementów IGBT przekształca to napięcie na trójfazowe do zasilania silników trakcyjnych. Regulacja przekształtnika odbywa się przy użyciu sterownika napędu. Do nadrzędnego sterowania służy sterownik pojazdu, który przetwarza wszystkie sygnały wejściowe i wyjściowe.

Agregat prądotwórczy uruchamiany jest elektrycznie z pulpitu maszynisty. Do kontroli parametrów technicznych i prawidłowego funkcjonowania agregat prądotwórczy jest wyposażony we własny system diagnostyczny. Podczas hamowania silniki trakcyjne pracują jako generatory. Wytwarzany w trakcie hamowania prąd trójfazowy jest prostowany przez przekształtnik, a napięcie stałe ładuje kondensator pośredni. Energia hamowania zasilane jest ogrzewanie, oświetlenie, wentylatory itd.

Zastosowane silniki trakcyjne znajdują się w szczelnej obudowie i przenosza napę za pośrednictwem przekładni dwustopniowej. Przekładnia wraz z silnikiem jest całkowicie odsprężynowana.

Autobus wyposażony jest w nowoczesny system diagnostyczny, który samodzielnie kontroluje główne układy pojazdu. W przypadku wystapienia usterki system diagnostyczny samodzielnie odłącza uszkodzone urządzenie, przekazując jednocześnie informację na stanowisko maszynisty oraz generuje komunikat do komputera pokładowego. Ułatwia to obsłudze wyszukiwanie i usuwanie ewentualnych usterek [7].
Schemat ideowy układu napędowego przedstawiono na rys. 17 .

\section{d) Uniwersalny układ napędowy Power Pack firmy MTU}

Firma MTU z Friedrichshafen produkuje i dostarcza swoim klientom układ napędowy typu $6 \mathrm{H} 1800 \mathrm{w}$ oparciu o silniki spalinowe z rodziny 183 o mocach $315 \div 360 \mathrm{~kW}$ z prądnicą główną o mocy dochodzącej do $350 \mathrm{~kW}$. Układ ten oprócz głównych zespołów (silnik-prądnica) zabudowanych na wspólnej ramie (mocowanej pod ostoją pojazdu) posiada również zamocowane układy chłodzące, zbiorniki, thumiki wylotu spalin, filtry, prądnice pomocnicze, układy napędów pomocniczych itd. [23].

Proponowany układ jest na tyle uniwersalny, że może być stosowany w wielu nowoczesnych autobusach szynowych. Niewątpliwą zaletą takiego układu jest również to, że może on być kształtowany w zależności od indywidualnych życzeń i wymagań producentów lekkich pojazdów szynowych (autobusów szynowych).

Ogólny widok układu Power-Pack firmy MTU dla zastosowań w lekkich pojazdach szynowych przedstawiono na rys. 18 .

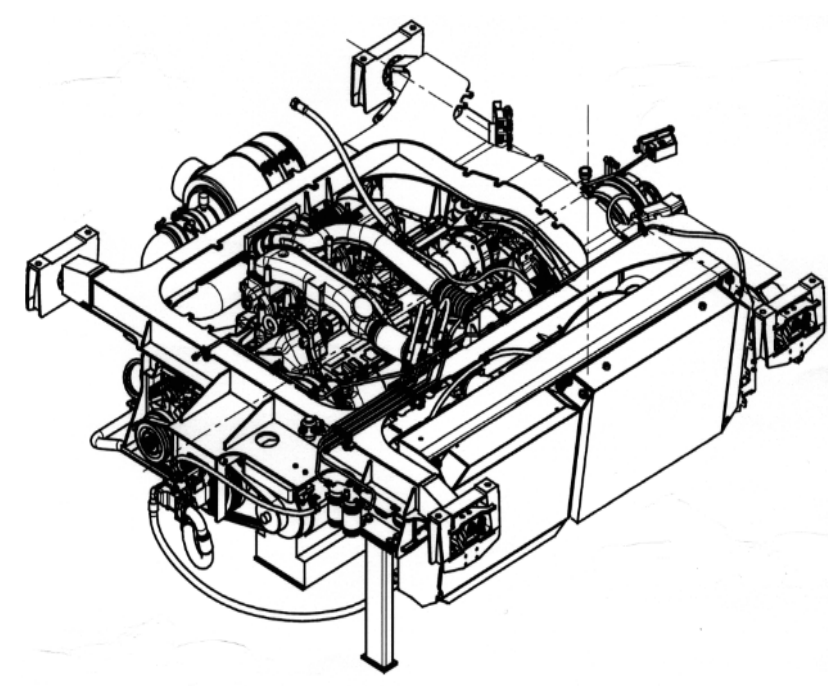

Rys.18. Widok układu Power-Pack firmy MTU dla autobusów szynowych

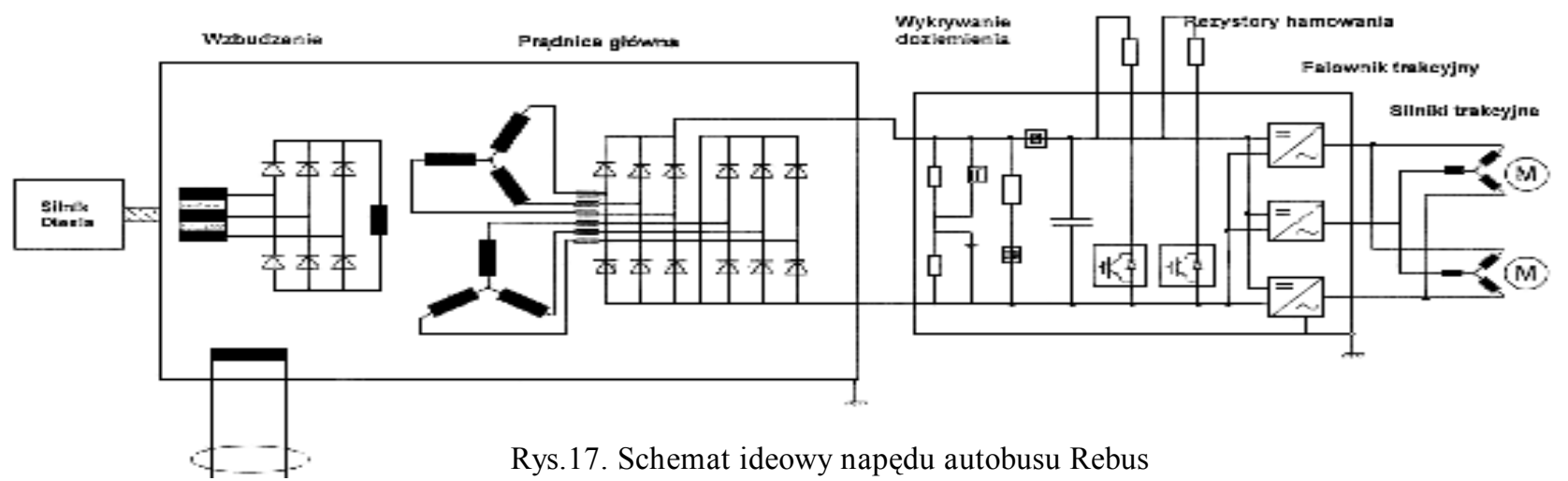




\section{GLÓWNE ZESPOLY I MASZYNY NAPE- DÓW SPALINOWO-ELEKTRYCZNYCH}

Napędy spalinowo-elektryczne lekkich pojazdów szynowych tworzą: silniki spalinowe, prądnice (główna i pomocnicza), prostowniki, przekształtniki, hamulce elektryczne (elektrodynamiczne), wały przegubowe, sprzęła, wały drążone, elektryczne silniki trakcyjne, przekładnie osiowe i napędowe zestawy kołowe.

Ponadto w działaniu pojazdów ważnymi aparatami i urządzeniami, nie wchodzącymi bezpośrednio do układów napędowych, są:

- układy peryferyjne silnika spalinowego, a więc układy paliwowe, w tym zbiorniki paliwa, układy olejowe, układy chłodzenia wodnego i chłodzenia powietrza doładowania (wentylatory, radiatory, chłodnice) i układ wydechowy

- rama główna w układach zawieszonych pod ostoją oraz rama zespołu prądotwórczego, na której znajduje się większość głównych maszyn i urządzeń, a więc przede wszystkim silnik spalinowy i prądnica

- układy sterujące zespołem prądotwórczym

- układy chłodzenia przekształtników, oporników hamowania oraz układy wentylacji silników trakcyjnych

- szafy lub skrzynie układów sterujących, orurowanie i okablowanie

- układy diagnostyki i sterowania całym pojazdem.

Dalsza część artykułu jest poświęcona opisom głównych maszyn i urządzeń zastosowanych w eksploatowanych lekkich pojazdach szynowych.

\subsection{Silniki spalinowe}

W lekkich pojazdach szynowych, w tym w autobusach szynowych, stosowane są silniki wysokoprężne czterosuwowe, najczęściej z wtryskiem bezpośrednim, chłodzone cieczą, charakteryzujące się przede wszystkim:

- niskim jednostkowym zużyciem paliwa

- niskim jednostkowym zużyciem oleju smarnego

- wydłużonym czasem pracy do naprawy głównej oraz przeglądu (rewizji) układu korbowotłokowego

- niskim oddziaływaniem na środowisko naturalne w zakresie emisji składników toksycznych do atmosfery

- zwartą budową i wymiarami umożliwiającymi zabudowę $\mathrm{w}$ niewielkiej przestrzeni, zarówno pod ostoją jak i w przedziale maszynowym.

Głównymi producentami i dostawcami silników spalinowych do zastosowania w lekkich pojazdach szynowych są firmy MTU i MAN oraz w mniejszym zakresie Deutz, Raba, Cummins i CAT.

\section{a) Silniki firmy MTU}

Firma MTU (z Friedrichshafen - Niemcy) specjalizuje się w produkcji silników spalinowych (dla pojazdów szynowych) zarówno rzędowych, leżących jak i stojących $z$ widlastym układem cylindrów. Bazą dla pierwszych silników „dozbrajanych” przez MTU były silniki OM442, OM444 i OM447 produkowane przez firmę Mercedes-Benz [28].

Silniki te były szeroko stosowane w lekkich spalinowych zespołach trakcyjnych jak i autobusach szynowych (pierwszym autobusem produkowanym w kraju był 208M (SA104 - SA122) z KolzamuRacibórz).

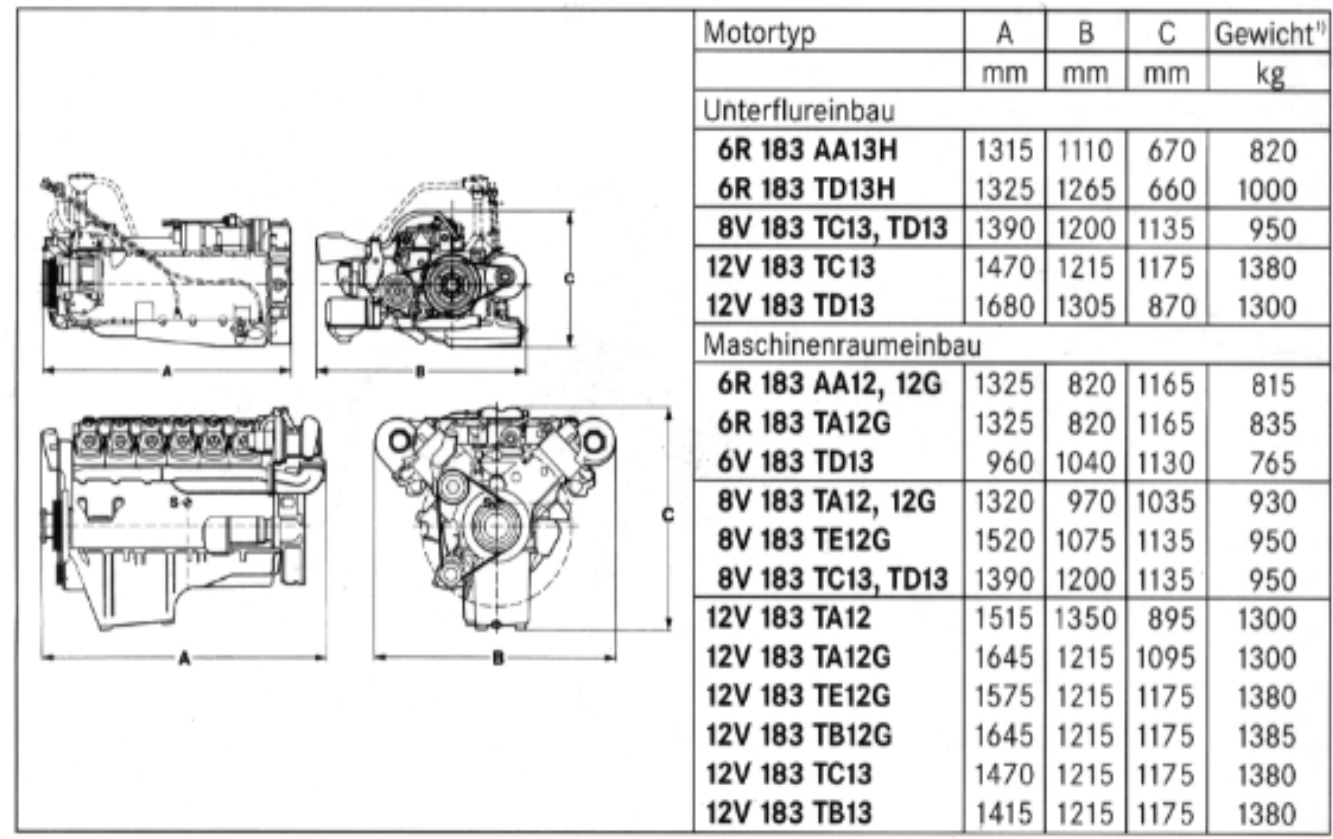

Motortyp - typ silnika

Gewicht - masa

Unterflureinbau zabudowa podpodłogowa

Maschinenraumainbau - zabudowa w przedziale maszynowym

Rys.19. Ogólny widok silników z rodziny 183 do zastosowań kolejowych [28] 
Ogólny widok silników MTU z rodziny $183 \mathrm{w}$ wersji leżącej (6R) i stojącej $(6 \mathrm{~V}, 8 \mathrm{~V}, 12 \mathrm{~V})$ do zastosowań podpodłogowych i zabudowy w przedziałach maszynowych przedstawiono na rys. 19 i 20 .

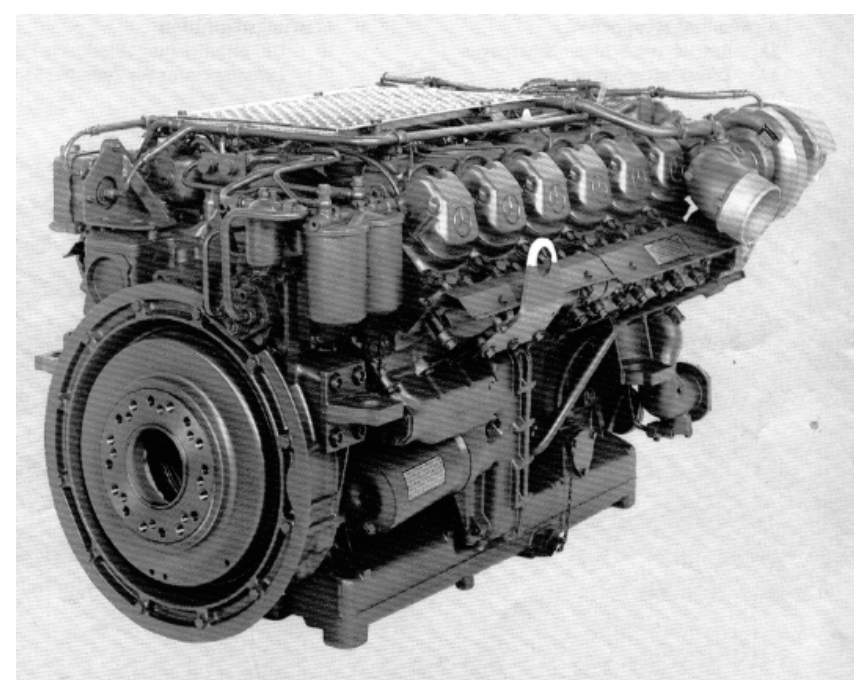

Rys.20. Ogólny widok silnika 12V183 do zabudowy w przedziale maszynowym

Najnowszym osiagnięciem firmy MTU są silniki z rodziny $6 \mathrm{H} 1800$ do zastosowań kolejowych, posiadające następujące cechy i wyposażenie [23]:

- połączenie z przekładnią typu SAE1

- czterozaworowe cylindry

- turobosprężarkę i chłodnicę powietrza

- pompę wtryskową (na każdy cylinder)

- system PLD (pompa-obciążenie-dysza)

- sterowanie elektroniczne TEMIC
- moduł elektroniki dla optymalnej charakterystyki (w wykonaniu kolejowym)

- rozrusznik 24V

- filtr i wirówka oleju

- napędy pomocnicze na KGS.

Silniki z rodziny $6 \mathrm{H} 1800$ posiadają moce od 315 do $360 \mathrm{~kW}$ i charakteryzują się niskim oddziaływaniem na środowisko naturalne (emisja spalin wg UIC624 [31] - badanie wg ISO 8178-4 cykl F oraz wg 88/77/EWG i 91/542/EG Euro III wg ESC i ELR).

Ogólny widok silnika przedstawiono na rys. 21.

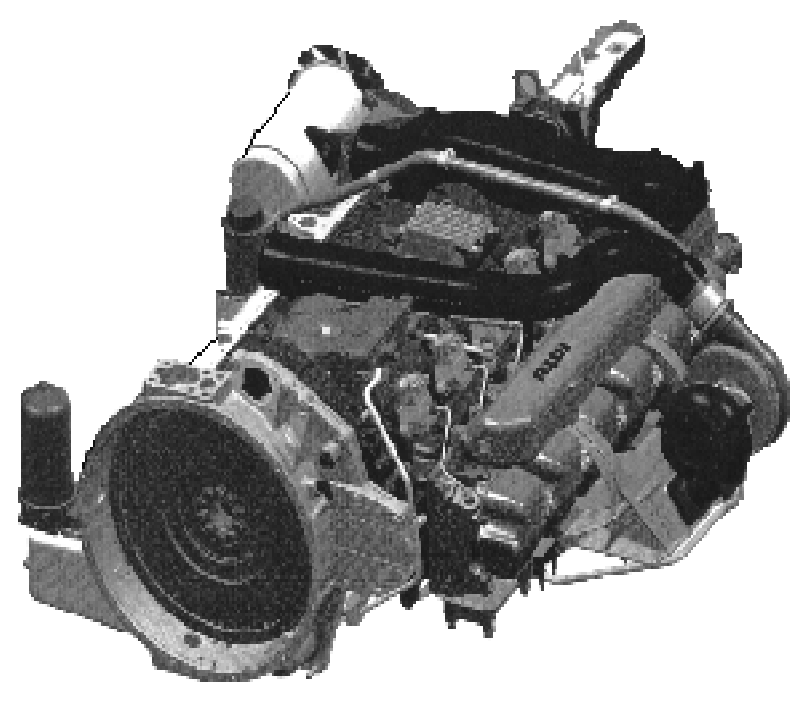

Rys.21. Ogólny widok silnika 6H1800 R80 firmy MTU

Główne parametry silników firmy MTU do zastosowań kolejowych przedstawiono w tabeli 3.

\section{Glówne parametry silników spalinowych firmy MTU zastosowanych lub możliwych do zastosowania w lekkich wieloczlonowych pojazdach szynowych}

\begin{tabular}{|c|c|c|c|c|c|c|c|}
\hline \begin{tabular}{lr|} 
Typ silnika spalinowego \\
Producent(kraj)
\end{tabular} & $\begin{array}{c}\text { Jednostka } \\
\text { miary }\end{array}$ & $\begin{array}{l}\text { 6H1800 R80- } \\
\text { R83 } \\
\text { i R80P-R83P } \\
\text { Niemcy } \\
\end{array}$ & $\begin{array}{l}\text { 6R183TD13H } \\
\text { Niemcy }\end{array}$ & $\begin{array}{l}\text { 6R183TD13H } \\
\text { Niemcy }\end{array}$ & $\begin{array}{l}\text { 12V183TD13 } \\
\text { Niemcy }\end{array}$ & $\begin{array}{c}\text { 12V183TC13 } \\
\text { Niemcy }\end{array}$ & $\begin{array}{c}\text { 12V183TB13 } \\
\text { Niemcy }\end{array}$ \\
\hline Moc znamionowa & $\mathrm{kW}$ & $315 \div 360$ & 275 & 315 & 564 & 485 & 550 \\
\hline Obroty znamionowe & $1 / \min$ & 1800 lub 1900 & 1900 & 1900 & 2100 & 2100 & 2100 \\
\hline Moment obrotowy & $\mathrm{Nm}$ & 2200 & - & - & - & - & - \\
\hline Pojemność skokowa & $\mathrm{dcm}^{3}$ & 12,82 & 11,97 & 11,97 & 21,93 & - & - \\
\hline Średnica / skok tłoka & $\mathrm{mm} / \mathrm{mm}$ & $128 / 166$ & $128 / 155$ & $128 / 155$ & $128 / 142$ & - & - \\
\hline Jednostkowe zużycie paliwa & $\mathrm{g} / \mathrm{kWh}$ & 195 & 194 & 194 & 198 & - & - \\
\hline Jednostkowe zużycie oleju & $\mathrm{g} / \mathrm{kWh}$ & $\leq 1$ & $\leq 1$ & $\leq 1$ & $\leq 1$ & - & - \\
\hline Masa silnika & $\mathrm{kg}$ & 1050 & 1020 & 1020 & 1515 & 1380 & 1380 \\
\hline $\begin{array}{l}\text { Gabaryty silnika (dł. x szer. } x \\
\text { wys.) }\end{array}$ & $\mathrm{mm}$ & $1480 \times 1415 \times 715$ & $1475 \times 1320 \times 655$ & $1475 \times 1320 \times 655$ & $1435 \times 1215 \times 1030$ & $1470 \times 1215 \times 1175$ & $1415 \times 1215 \times 1175$ \\
\hline $\begin{array}{l}\text { Trwałość silnika (czas do } \\
\text { naprawy głównej) }\end{array}$ & $\mathrm{h}$ & - & - & - & 36000 & - & - \\
\hline Układ i liczba cylindrów & - & $\begin{array}{c}\text { rzędowy/poziomy } \\
6 \\
\end{array}$ & $\begin{array}{c}\text { rzędowy/poziomy } \\
6 \\
\end{array}$ & $\begin{array}{c}\text { rzędowy/poziomy } \\
6 \\
\end{array}$ & $\begin{array}{c}\text { pionowy/widlasty } \\
12 \\
\end{array}$ & \begin{tabular}{|c|} 
pionowy/widlasty \\
12 \\
\end{tabular} & $\begin{array}{c}\text { pionowy/widlasty } \\
12 \\
\end{array}$ \\
\hline Toksyczność spalin & & Euro III/UIC II & Euro II & Euro II & Euro II & Euro II & Euro II \\
\hline
\end{tabular}




\section{b) Silniki firmy MAN}

Firma MAN specjalizuje się również (podobnie jak MTU) w produkcji silników spalinowych do zastosowań kolejowych, zarówno leżących jak i stojących. Silniki te cechują się dużą żywotnością i zwartością konstrukcji oraz posiadają elektroniczną regulację EDC i system wtryskowy Common-Rail. Spełniają one również wymagania Euro II i Euro III w zakresie emisji składników toksycznych spalin do atmosfery [6 i 31].

Ogólny widok silnika zastosowanego w najnowocześniejszych autobusach firmy Bombardier przedstawiono na rys.22, a główne parametry silników firmy MAN do zastosowań kolejowych w tabeli 4.

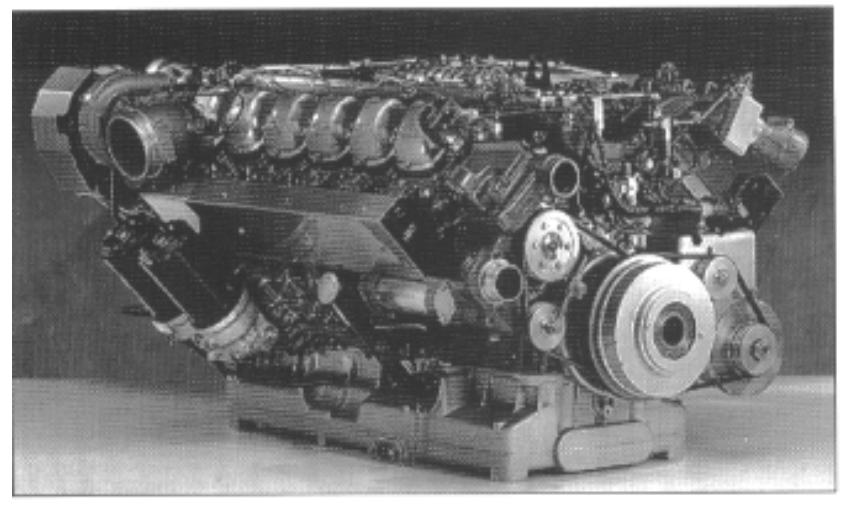

Rys.22. Ogólny widok silnika MAN D2842 LE602

Główne parametry silników spalinowych firmy MAN zastosowanych lub możliwych do zastosowania w lekkich wieloczlonowych pojazdach szynowych

Tabela 4

\begin{tabular}{|c|c|c|c|c|c|c|c|}
\hline \begin{tabular}{|lr} 
& Typ silnika spalinowego \\
Parametr & Producent(kraj) \\
\end{tabular} & $\begin{array}{c}\text { Jednostka } \\
\text { miary }\end{array}$ & $\begin{array}{l}\text { D2866 } \\
\text { LUH21 }\end{array}$ & $\begin{array}{c}\text { D2876 } \\
\text { LUE621 }\end{array}$ & $\begin{array}{c}\text { D2866 } \\
\text { LU }\end{array}$ & $\begin{array}{c}\text { D2866 } \\
\text { LUE602 }\end{array}$ & $\begin{array}{c}\text { D2866 } \\
\text { LU }\end{array}$ & $\begin{array}{l}\text { D2876 } \\
\text { LUH02 }\end{array}$ \\
\hline Moc znamionowa & $\mathrm{kW}$ & 257 & 257 & 301 & 300 & 265 & 316 \\
\hline Obroty znamionowe & $1 / \mathrm{min}$ & 2000 & 2000 & 1900 & 2100 & 1900 & 2000 \\
\hline Moment obrotowy & $\mathrm{Nm}$ & 1227 & 1227 & 1730 & 1730 & 1850 & 1850 \\
\hline Pojemność skokowa & $\mathrm{dcm}^{3}$ & 11,967 & 12,82 & 11,97 & 11,97 & 11,97 & 12,81 \\
\hline Średnica / skok tłoka & $\mathrm{mm} / \mathrm{mm}$ & $128 / 155$ & $128 / 166$ & $128 / 155$ & $128 / 155$ & $128 / 155$ & $128 / 166$ \\
\hline Jednostkowe zużycie paliwa & $\mathrm{g} / \mathrm{kWh}$ & 191 & 190 & 193 & 193 & 194 & 198 \\
\hline Układ i liczba cylindrów & - & liniowy 6 & rzędowy/lezacy 6 & rzędowy/lezący 6 & rzędowy/leżący 6 & rzędowy/lezący 6 & rzędowy/lezący 6 \\
\hline Toksyczność spalin & & Euro II & Euro III & - & - & - & - \\
\hline
\end{tabular}

Główne parametry silników spalinowych firmy MAN zastosowanych lub możliwych do Zastosowania w lekkich wieloczlonowych pojazdach szynowych

Tabela 4 c.d.

\begin{tabular}{|l|c|c|c|c|c|c|}
\hline \multicolumn{1}{|c|}{ Typ silnika spalinowego } & Jednostka & $\begin{array}{c}\text { D2842 } \\
\text { LUH03 }\end{array}$ & $\begin{array}{c}\text { D2842 } \\
\text { LE604 }\end{array}$ & $\begin{array}{c}\text { D2842 } \\
\text { LE603 }\end{array}$ & $\begin{array}{c}\text { D2842 } \\
\text { LE602 }\end{array}$ & $\begin{array}{c}\text { D2842 } \\
\text { LE606 }\end{array}$ \\
\hline Marametr & $\mathrm{kW}$ & 338 & 480 & 500 & 588 & 662 \\
\hline Obroty znamionowe & $1 / \mathrm{min}$ & 2000 & 1550 & 2100 & 2100 & 2100 \\
\hline Moment obrotowy & $\mathrm{Nm}$ & 2000 & 3100 & 2900 & 3200 & 3300 \\
\hline Pojemność skokowa & $\mathrm{dcm}^{3}$ & 12,81 & 21,93 & 21,93 & 21,93 & 21,93 \\
\hline Średnica / skok tłoka & $\mathrm{mm} / \mathrm{mm}$ & $128 / 166$ & $128 / 142$ & $128 / 142$ & $128 / 142$ & $128 / 142$ \\
\hline Jednostkowe zużycie paliwa & $\mathrm{g} / \mathrm{kWh}$ & 198 & 198 & 198 & 198 & 202 \\
\hline Układ i liczba cylindrów & - & rzędowy/leżacy 6 & widlasty 12 & widlasty 12 & widlasty 12 & widlasty 12 \\
\hline Toksyczność spalin & & - & - & - & - & - \\
\hline
\end{tabular}

\section{c) Silniki firmy RABA}

Silniki węgierskiej firmy RABA od niedawna znalazły zastosowanie $\mathrm{w}$ autobusach szynowych. Również w Polsce w najnowszych autobusach szynowych SA107 i SA109 produkcji Kolzam-Racibórz wykonywanych na podstawie dokumentacji IPS „TABOR” Poznań zastosowano power-pack z silnikiem D10UTSSL o mocy 190kW firmy Raba [12].
Silniki Raby w wersji leżącej posiadają moce od 160 do $235 \mathrm{~kW}$ a w wersji stojącej od 190 do $235 \mathrm{~kW}$ i spełniają wymagania Euro II w zakresie emisji substancji szkodliwych.

Ogólny widok silnika Raba w wersji leżącej przedstawiono na rys.23, a główne parametry silników w tabeli 5. 

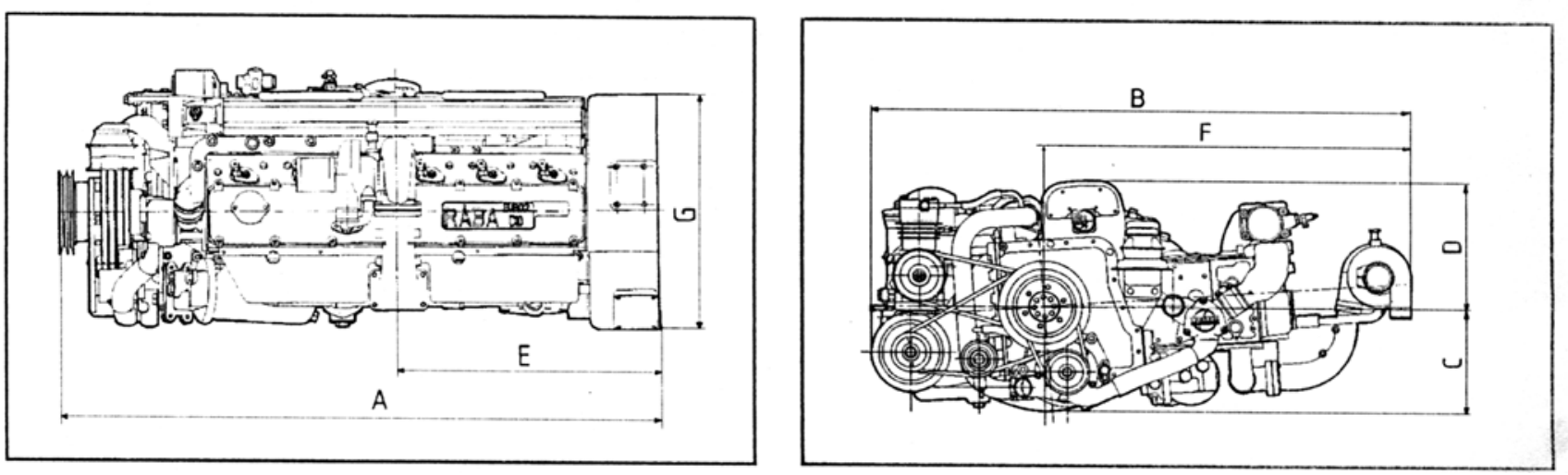

Rys.23. Silnik firmy Raba w wersji leżącej

Glówne parametry silników spalinowych firmy Raba zastosowanych lub możliwych do zastosowania w lekkich wieloczlonowych pojazdach szynowych

Tabela 5

\begin{tabular}{|c|c|c|c|c|c|c|c|}
\hline \begin{tabular}{|r|r|r|r|r|} 
Typ silnika spalinowego \\
Producent(kraj)
\end{tabular} & $\begin{array}{c}\text { Jednostka } \\
\text { miary }\end{array}$ & $\begin{array}{l}\text { D10UTLL } \\
206 \text { E2 } \\
\text { Wegry }\end{array}$ & $\begin{array}{l}\text { D10UTLL } \\
235 \text { E2 } \\
\text { Wegry } \\
\end{array}$ & $\begin{array}{l}\text { D10UTLL } \\
\text { 206 E2 } \\
\text { Wegry } \\
\end{array}$ & $\begin{array}{l}\text { D10UTLL } \\
235 \text { E2 } \\
\text { Wegry } \\
\end{array}$ & $\begin{array}{l}\text { D10UTLL } \\
206 \text { E2 } \\
\text { Wegry }\end{array}$ & $\begin{array}{l}\text { D10UTLL } \\
235 \text { E2 } \\
\text { Wegry } \\
\end{array}$ \\
\hline Moc znamionowa & $\mathrm{kW}$ & 206 & 235 & 206 & 235 & 206 & 235 \\
\hline Obroty znamionowe & $1 / \mathrm{min}$ & 2100 & 2100 & 2200 & 2200 & 2100 & 2100 \\
\hline Moment obrotowy & $\mathrm{Nm}$ & 1115 & 1335 & 1195 & 1270 & 1115 & 1334 \\
\hline Pojemność skokowa & $\mathrm{dcm}^{3}$ & 10,35 & 10,35 & 10,35 & 10,35 & 10,35 & 10,35 \\
\hline Średnica / skok tłoka & $\mathrm{mm} / \mathrm{mm}$ & $121 / 150$ & $121 / 150$ & $121 / 150$ & $121 / 150$ & $121 / 150$ & $121 / 150$ \\
\hline Jednostkowe zužcie paliwa & $\mathrm{g} / \mathrm{kWh}$ & 199,4 & 199,8 & 202 & 202 & 199,4 & 199,8 \\
\hline Jednostkowe zużycie oleju & $\mathrm{g} / \mathrm{kWh}$ & 1 & 1 & 1 & 1 & 1 & 1 \\
\hline Masa silnika & $\mathrm{kg}$ & - & - & - & - & - & - \\
\hline $\begin{array}{l}\text { Gabaryty silnika (dl. x szer. x } \\
\text { wys.) }\end{array}$ & $\mathrm{mm}$ & $1388,6 \times 1395 \times 544$ & $1338,6 \times 1395 \times 544$ & $1321,5 \times 753,5 \times 1142$ & $1321,5 \times 753,5 \times 1142$ & $1321,5 \times 753,5 \times 1142$ & $1321,5 \times 753,5 \times 1142$ \\
\hline $\begin{array}{l}\text { Trwałość silnika (czas do } \\
\text { naprawy głównej) }\end{array}$ & $\mathbf{h}$ & 20000 & 20000 & 20000 & 20000 & 20000 & 20000 \\
\hline Układ i liczba cylindrów & - & $\begin{array}{c}\text { rzędowy/poziomy } \\
6 \\
\end{array}$ & $\begin{array}{c}\text { rzędowy/poziomy } \\
6 \\
\end{array}$ & rzędowy/pionowy 6 & rzędowy/pionowy 6 & rzędowy/pionowy 6 & rzędowy/pionowy 6 \\
\hline Toksyczność spalin & & Euro II & Euro II & Euro I, II & Euro I & Euro II & Euro II \\
\hline
\end{tabular}

\section{d) Silniki firmy Deutz}

Silniki firmy Deutz produkowane są przede wszystkim w wersji stojącej w zakresie mocy $300 \div$ $500 \mathrm{~kW}$ i cechują się toksycznością spalin zgodnie z Euro II, Euro III i Com II [31]. Główne parametry tych silników przedstawiono w tabeli 6 .

Glówne parametry silników spalinowych firmy Deutz zastosowanych lub możliwych do zastosowania w lekkich wieloczlonowych pojazdach szynowych

Tabela 6

\begin{tabular}{|c|c|c|c|c|c|c|c|}
\hline \begin{tabular}{|rr} 
& Typ silnika spalinowego \\
Parametr & Producent(kraj) \\
\end{tabular} & $\begin{array}{c}\text { Jednostka } \\
\text { miary }\end{array}$ & $\begin{array}{l}\text { BF6M } \\
1015 C\end{array}$ & $\begin{array}{c}\text { BF6M } \\
1015 C P\end{array}$ & $\begin{array}{l}\text { BF8M } \\
1015 C\end{array}$ & $\begin{array}{c}\text { BF8M } \\
\text { 1015CP }\end{array}$ & $\begin{array}{l}\text { BF6M } \\
\text { 2015C }\end{array}$ & $\begin{array}{c}\text { BF8M } \\
2015 C P\end{array}$ \\
\hline Moc znamionowa & $\mathrm{kW}$ & 300 & 330 & 400 & 440 & 330 & 500 \\
\hline Obroty znamionowe & $1 / \mathrm{min}$ & 2100 & 2100 & 2100 & 2100 & 2100 & 2100 \\
\hline Moment obrotowy & $\mathrm{Nm}$ & 1773 & 2041 & 2364 & 2721 & - & - \\
\hline Pojemność skokowa & $\mathrm{dcm}^{3}$ & 11,91 & 11,91 & 15,87 & 15,87 & 11,91 & 15,87 \\
\hline Średnica / skok tłoka & $\mathrm{mm} / \mathrm{mm}$ & $132 / 145$ & $132 / 145$ & $132 / 145$ & $132 / 145$ & $132 / 145$ & $132 / 145$ \\
\hline Jednostkowe zużycie paliwa & $\mathrm{g} / \mathrm{kWh}$ & - & - & - & - & - & - \\
\hline Jednostkowe zużycie oleju & $\mathrm{g} / \mathrm{kWh}$ & - & - & - & - & - & - \\
\hline Masa silnika & $\mathrm{kg}$ & 850 & 850 & 1093 & 1093 & 920 & 1160 \\
\hline Gabaryty silnika (dł. x szer. x wys.) & $\mathrm{mm}$ & $1041 \times 926 \times 1098$ & $1041 \times 926 \times 1098$ & $1008 \times 950 \times 1740$ & $1008 \times 950 \times 1740$ & $1140 \times 1305 \times 886$ & $1182 \times 975 \times 1152$ \\
\hline $\begin{array}{l}\text { Trwałość silnika (czas do naprawy } \\
\text { głównej) }\end{array}$ & $\mathbf{h}$ & - & - & - & - & - & - \\
\hline Układ i liczba cylindrów & - & $6 \mathrm{~V}$ & $6 \mathrm{~V}$ & $8 \mathrm{~V}$ & $8 \mathrm{~V}$ & $6 \mathrm{~V}$ & $8 \mathrm{~V}$ \\
\hline Toksyczność spalin & & Euro II & Euro II & Euro II & Euro II & Euro III & Com II \\
\hline
\end{tabular}




\section{e) Silniki firmy Cummins}

Silniki firmy Cummins (W. Brytania) znalazły zastosowanie $\mathrm{w}$ spalinowych wagonach motorowych oraz w spalinowych zespołach trakcyjnych. Budowane są zarówno w wersjach stojących i leżących. Parametry starszej generacji silników firmy Cummins przedstawiono w tabeli 7.

Najnowsze silniki firmy Cummins zastosowane w lekkich pojazdach szynowych to QSK 19-L o mocy $522 \mathrm{~kW}$, spełniający amerykańskie wymagania Tier 3 w zakresie emisji składników toksycznych do atmosfery, oraz QSK 19-R o mocy $560 \mathrm{~kW}$ [21].

Oba silniki przedstawiono na rys.24 i 25 .

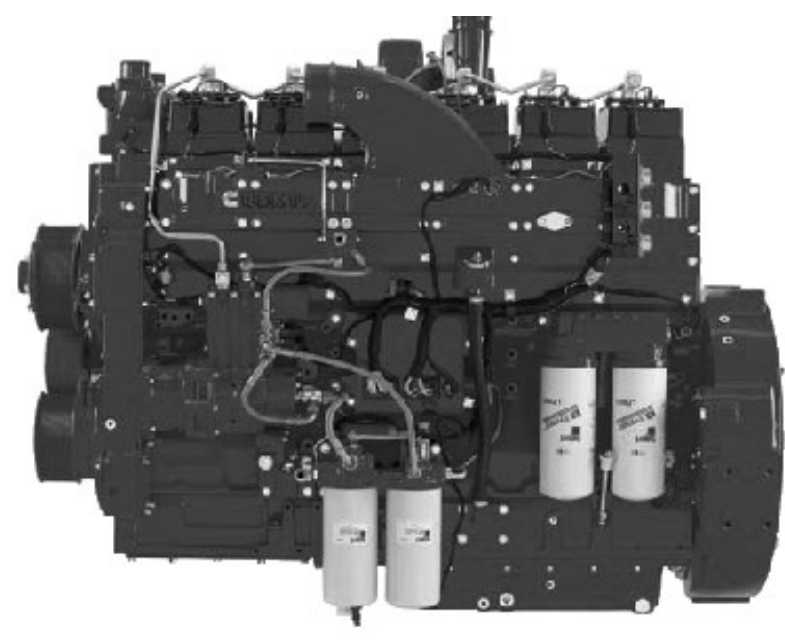

Rys.24. Ogólny widok silnika QSK 19-L

Rys.26. Silnik firmy Caterpillar (CAT)

Glówne parametry silników spalinowych firmy Cummins i Caterpillar zastosowanych lub możliwych do zastosowania w lekkich wieloczlonowych pojazdach szynowych

Tabela 7

\begin{tabular}{|c|c|c|c|c|c|c|}
\hline $\begin{array}{|rr|} & \text { Typ silnika spalinowego } \\
\text { Parametr } & \text { Producent(kraj) }\end{array}$ & $\begin{array}{c}\text { Jednostka } \\
\text { miary }\end{array}$ & $\begin{array}{c}\text { KTA 19R } \\
\text { Cummins } \\
\text { Wielka Brytania }\end{array}$ & $\begin{array}{c}\text { NTA855R1 } \\
\text { Cummins } \\
\text { Wielka Brytania }\end{array}$ & $\begin{array}{c}\text { KTA19L } \\
\text { Cummins } \\
\text { Wielka Brytania }\end{array}$ & $\begin{array}{l}\text { C15 } \\
\text { Caterpillar } \\
\text { USA }\end{array}$ & $\begin{array}{c}\text { C16 } \\
\text { Caterpillar } \\
\text { USA }\end{array}$ \\
\hline Moc znamionowa & $\mathrm{kW}$ & 448 & 298 & 448 & $317 \div 429$ & $373 \div 492$ \\
\hline Obroty znamionowe & $1 / \mathrm{min}$ & 2100 & 2100 & 2100 & $1800 \div 2100$ & $1800 \div 2100$ \\
\hline Moment obrotowy & $\mathrm{Nm}$ & 2260 & 1560 & 2237 & - & - \\
\hline Pojemność skokowa & $\mathrm{dcm}^{3}$ & 19 & 14 & 19 & 14,6 & 15,8 \\
\hline Średnica / skok tłoka & $\mathrm{mm} / \mathrm{mm}$ & $159 / 159$ & $140 / 152$ & $159 / 159$ & $137 / 165$ & $140 / 171$ \\
\hline Jednostkowe zużycie paliwa & $\mathrm{g} / \mathrm{kWh}$ & 206 & 220 & - & - & - \\
\hline Jednostkowe zužycie oleju & $\mathrm{g} / \mathrm{kWh}$ & - & - & - & - & - \\
\hline Masa silnika & $\mathrm{kg}$ & 2088 & 1305 & 1691 & 1332 & 1332 \\
\hline Gabaryty silnika (dl. x szer. $\mathrm{x}$ wys.) & $\mathrm{mm}$ & $1530 \times 1952,8 \times 787,5$ & $1537,5 \times 2105,5 \times 732$ & $1573 \times 1377 \times 796$ & $1661 \times 901 \times 1336$ & $1661 \times 901 \times 1336$ \\
\hline $\begin{array}{l}\text { Trwałość silnika (czas do naprawy } \\
\text { głównej) }\end{array}$ & $\mathrm{h}$ & - & - & - & - & - \\
\hline Układ i liczba cylindrów & - & $\begin{array}{c}\text { rzędowy/poziomy } \\
6\end{array}$ & $\begin{array}{c}\text { rzędowy/poziomy } \\
6\end{array}$ & $\begin{array}{c}\text { rzędowy/pionowy } \\
6 \\
\end{array}$ & $\begin{array}{c}\text { rzędowy/pionowy } \\
6\end{array}$ & $\begin{array}{c}\text { rzędowy/pionowy } \\
6 \\
\end{array}$ \\
\hline Toksyczność spalin & & UIC 624 & UIC 624 & - & Tier 2 & Tier 2 \\
\hline
\end{tabular}




\subsection{Prądnice glówne}

W lekkich pojazdach szynowych, zarówno w spalinowych zespołach trakcyjnych jak i autobusach szynowych, stosowane są prądnice główne synchroniczne (prądu przemiennego). Opisy wybranych prądnic podano poniżej.

a) Prądnica główna spalinowego zespołu trakcyjnego serii BM/BS92 jest prądnicą synchroniczną i należy do specjalnych kolejowych zastosowań.

Prądnica jest maszyną jednołożyskową i jest połączona bezpośrednio $\mathrm{z}$ silnikiem spalinowym. Jej średnica umożliwia zabudowę pod ostoją członu napędowego. Prądnica jest maszyną sześciobiegunowa, $\mathrm{z}$ przewietrzaniem własnym i posiada wbudowaną wzbudnicę oraz wyposażona jest $\mathrm{w}$ wirujący mostek diodowy. Regulacje obciążenia zabezpiecza bezpośrednio elektroniczne urządzenie regulacyjne [13].

Stojan prądnicy składa się ze stalowych blach biegunów wewnętrznych dla głównej maszyny oraz biegunów zewnętrznych dla wzbudnicy. Prądnica wirnik ma wyraźne bieguny. Łożyska cylindrowe prądnicy są bezsmarowe, izolowane elektrycznie.

Połączenie silnika spalinowego i prądnicy nie przenosi żadnych momentów szkodliwych dla zawieszenia agregatu. Prądnica bezszczotkowa nie posiada żadnych, poza łożyskami, części zużywających się [14].

Ogólny widok prądnicy przedstawiono na rys. 27.

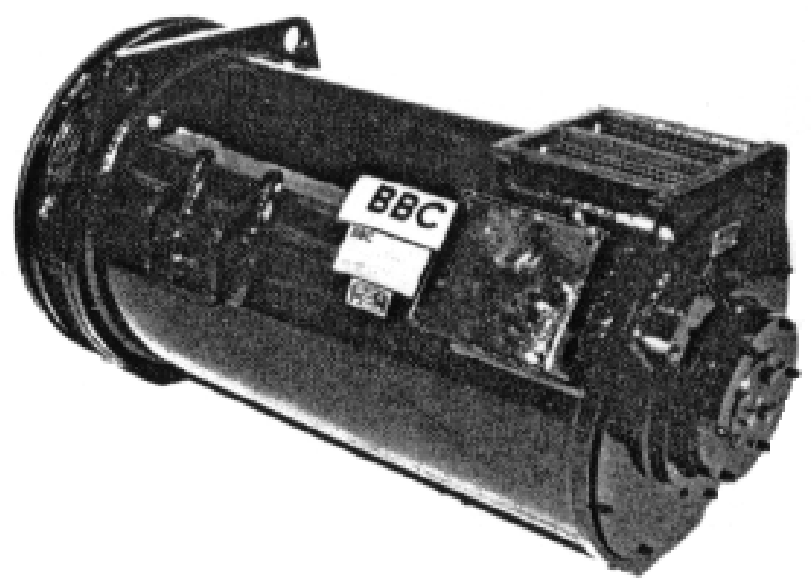

Rys.27. Prądnica główna synchroniczna dla zespołu serii $\mathrm{BM} / \mathrm{BS} 92$

b) Prądnica glówna spalinowego zespołu trakcyjnego VT610 jest prądnicą synchroniczna, bezszczotkową i jednołożyskową [4].

Maszyna jest bezpośrednio połączona z silnikiem spalinowym. Całość zabudowana jest pod ostoją wagonu.

Ogólny widok prądnicy przedstawiono na rys.28.

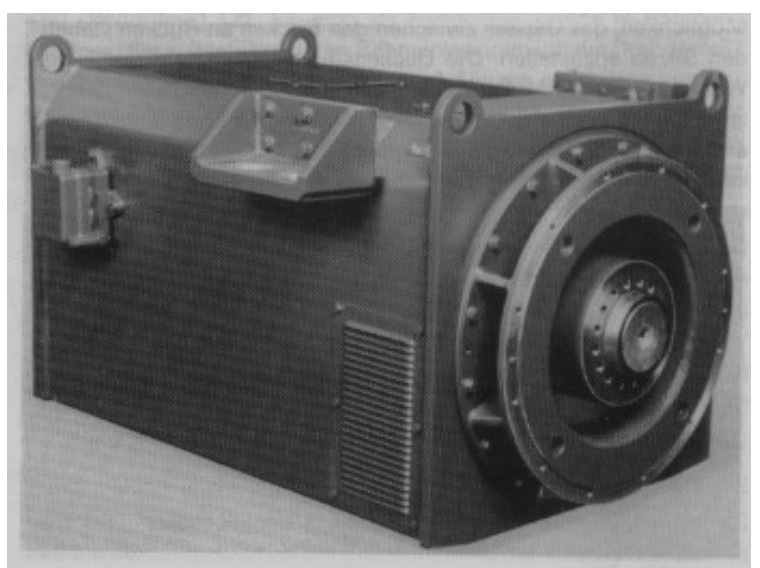

Rys.28. Prądnica główna synchroniczna typu 1FC6352-6 dla zespołu serii VT610

c) Prądnice glówne autobusów szynowych GTW 2/6 i 4/8 oraz Rebus są maszynami synchronicznymi, napędzanymi silnikami wysokoprężnymi. Wytwarzane przez prądnice napięcie przemienne jest prostowane i doprowadzane do obwodu pośredniego przekształtnika, a następnie do silników trakcyjnych [2, 7].

d) Prądnica główna autobusu szynowego VT644 (BR644) jest maszyną synchroniczną, połączoną bezpośrednio z silnikiem spalinowym. Oba główne urządzenia zamontowane są na wspólnej ramie. Prądnica jest maszyną $\mathrm{z}$ własnym przewietrzaniem, zintegrowaną $\mathrm{z}$ bezszczotkową wzbudnicą.

Regulacja napięcia prądnicy odbywa się następująco: pomiędzy obrotami 1600 1/min i max (od 1900 $1 / \mathrm{min}$ ) regulacja jest zależna od obciążenia napięcia znamionowego, natomiast jeżeli obroty spadają poniżej 1600 1/min obniża się napięcie wejściowe wraz z obniżającymi się obrotami.

Podstawowe parametry prądnicy są następujące:
1. moc

2. moc krótkotrwała

3. zakres obrotów

4. napięcie wyjściowe

5. współczynnik mocy

6. masa
$360 \mathrm{kVA}$, $400 \mathrm{kVA}$ przy $1900 \mathrm{1} / \mathrm{min}$, $1600 \div 19001 / \mathrm{min}$ $3 \times 490 \mathrm{~V}$ dla $16001 / \mathrm{min}$, $\cos \varphi=0,9$ $1250 \mathrm{~kg}$. e) Oprócz w/w do dyspozycji są prądnice następujących wytwórców:

- ABB (obecnie Bombardier) poleca prądnice synchroniczne $\mathrm{z}$ wbudowaną wzbudnicą $\mathrm{i}$ wirującym mostkiem z diodami dla regulacji. Prądnica jest maszyną bezszczotkową, dwułożyskową o małej średnicy. Do wykorzystania jest prądnica sześciobiegunowa typu WGxy450 przedstawiona na rys.29. 


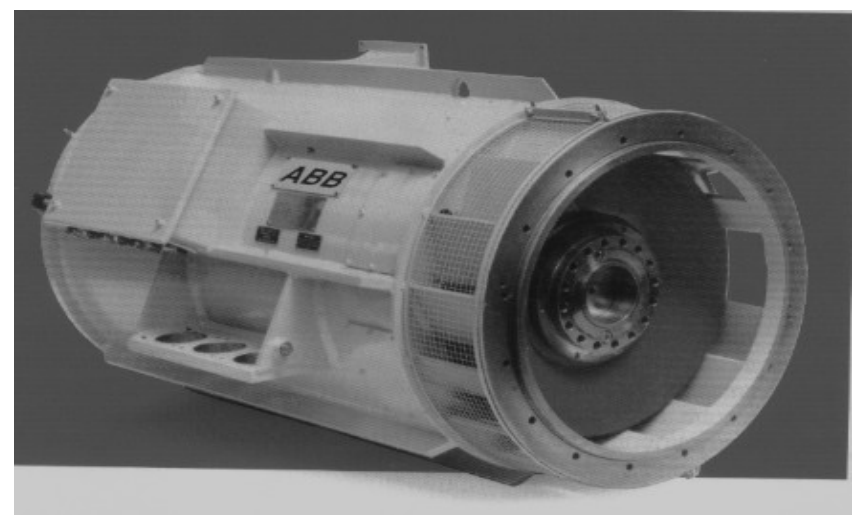

Rys.29. Prądnica główna typu WGxy450 firmy ABB

1. moc

$590 \mathrm{kVA}$

2. obroty:
- minimalne
- maksymalne
$600 \mathrm{obr} / \mathrm{min}$ $1800 \mathrm{obr} / \mathrm{min}$
3. częstotliwość
$30 \div 90 \mathrm{~Hz}$
4. napięcie wyjściowe
$1280 \mathrm{~V}$
$1900 \mathrm{~kg}$.

5. masa

VEM poleca prądnice główne serii DREBZ i DRLBZ o mocach $30 \mathrm{kVA}$ do $3000 \mathrm{kVA}$, napięcia od $400 \mathrm{~V}$ do $1800 \mathrm{~V}$; obrotach $1000 \div$ 2100 1/min, z przewietrzaniem własnym i obcym. Prądnice są bezszczotkowe $\mathrm{z}$ własną wzbudnicą i wirującym mostkiem diodowym. Uzwojenie prądnicy jest klasy cieplnej 200, impregnowane ciśnieniowo i kontrolowane termometrem oporowym zabudowanym $\mathrm{w}$ stojanie. Prądnice budowane są jako jedno- i dwułożyskowe $\mathrm{z}$ łożyskami nie wymagającymi obsługi i przystosowane do różnych połączeń i warunków zabudowy.

Zastosowanie prądnic jako maszyn głównych, pomocniczych i pokładowych dla wagonów silnikowych i autobusów szynowych z napędem spalinowo-elektrycznym i spalinowohydraulicznym zostały potwierdzone w eksploatacji.

Ogólny widok prądnicy firmy VEM przedstawiono na rys.30.

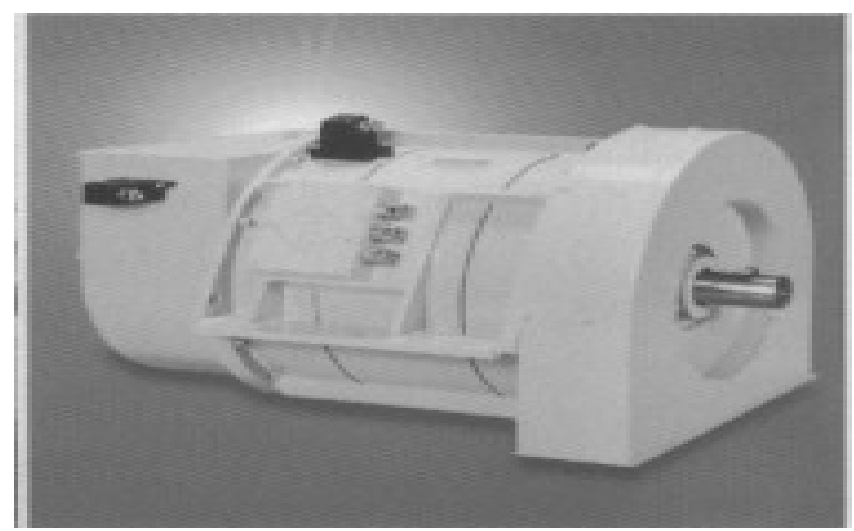

Rys.30. Synchroniczna prądnica firmy VEM dla zastosowań kolejowych
- firma Emit Żychlin poleca trójfazowe prądnice synchroniczne serii Gh i mGh, które z powodzeniem po niewielkich przeróbkach mogą być wykorzystane w napędach autobusów szynowych. Prądnice są maszynami do pracy ciagłej, w wykonaniu jedno- lub dwułożyskowym $\mathrm{z}$ kołnierzem i jednym napędowym końcem wału.

Na kadłubie zabudowana jest skrzynka zaciskowa. Prądnice budowane są dla napięć $400 \mathrm{~V} 50 \mathrm{~Hz}$ oraz $460 \mathrm{~V} 60 \mathrm{~Hz} \mathrm{z}$ czterema zaciskami uzwojenia stojanu, w klasie izolacji $\mathrm{H} \mathrm{z}$ impregnacją uzwojenia metodą próżniowociśnieniową.

Ponadto prądnice wyposażone są w elektroniczny regulator napięcia i są chłodzone powietrzem.

Ogólny widok prądnicy przedstawiono na rys. 31 .

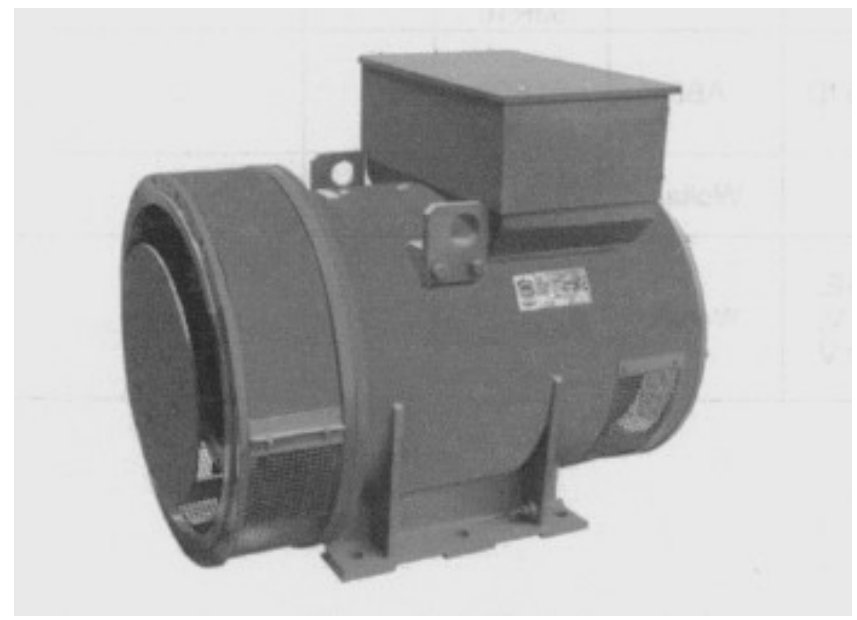

Rys.31. Prądnica synchroniczna firmy Emit Żychlin

\subsection{Przeksztaltniki (falowniki) trakcyjne}

Zadaniem przekształtników (falowników) trakcyjnych jest przekształcanie napięcia obwodu pośredniego (po wyprostowaniu przez prostownik) na napięcie trójfazowe do zasilania silników trakcyjnych.

Poniżej przedstawiono opisy wybranych przekształtników trakcyjnych, zastosowanych w lekkich pojazdach szynowych.:

- Przeksztaltnik trakcyjny zespołu serii BM/BS92 zawiera dwanaście tyrystorów, sześć diod jako zabezpieczenie oraz kondensatory komutacyjne i dławiki (cewki).

Połączenia obwodu wysokonapięciowego wyposażone są ponadto $\mathrm{w}$ zmiennik prądu i napięcia dla regulacji elektronicznej. Przekształtnik jest chłodzony powietrzem wytwarzanym przez wentylator napędzany elektrycznie i jest zabudowany we wnętrzu zespołu trakcyjnego [8].

Ogólny widok szafy $\mathrm{z}$ przekształtnikiem przedstawiono na rys.32. 


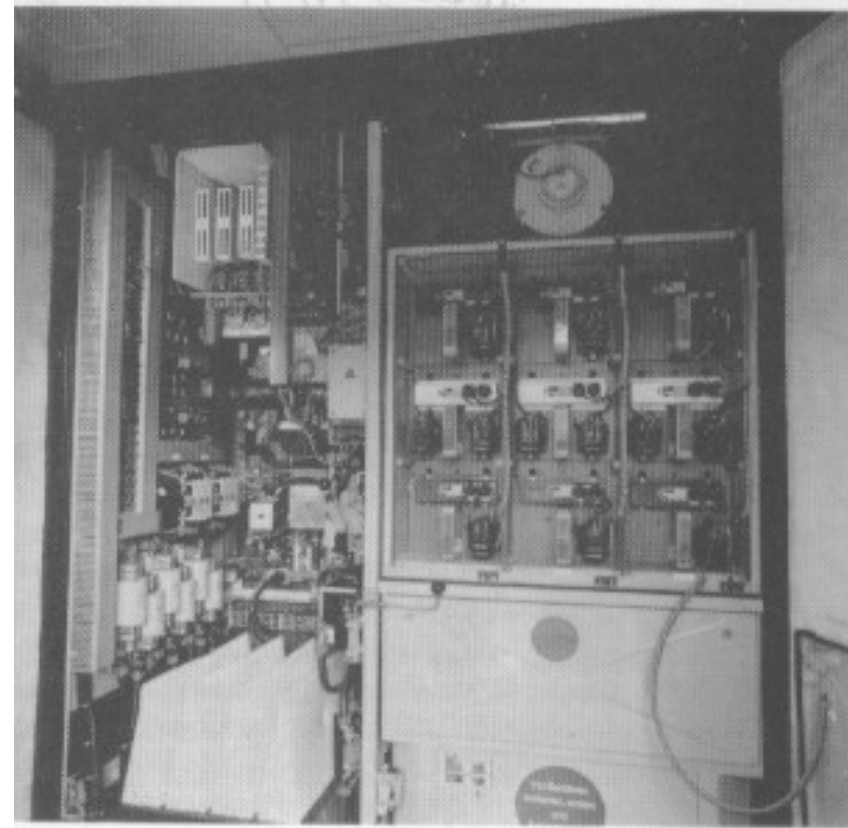

Rys.32. Przekształtnik trakcyjny, główny prostownik i zabezpieczenie dla przeniesienia napędu zespołu serii $\mathrm{BM} / \mathrm{BS} 92$

- Przeksztaltnik trakcyjny spalinowego zespołu VT610 jest zbudowany w oparciu o tyrystory GTO i chłodzony olejem. Zamknięty jest w skrzyni i mocowany do ostoi wagonu. Przekształtnik zasila trzy silniki asynchroniczne z różnym napięciem i częstotliwością [4].

Ogólny widok przekształtnika przedstawiono na rys.33.

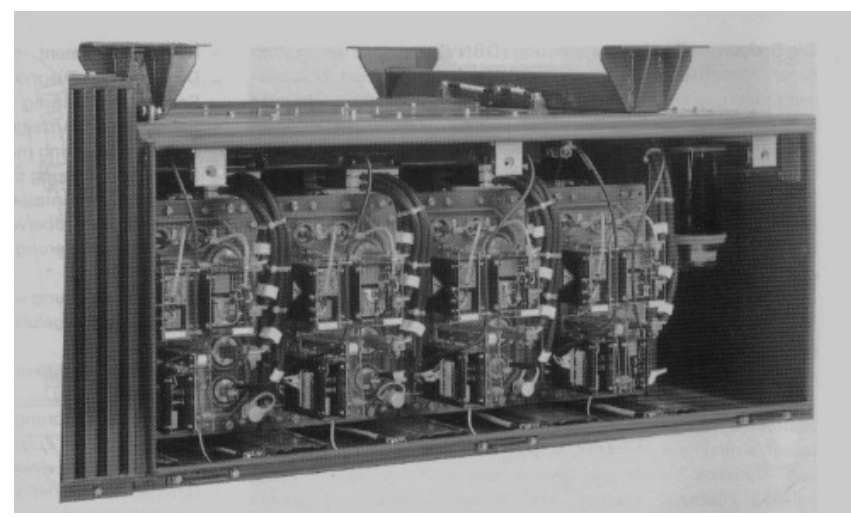

Rys.33. Przekształtnik trakcyjny z tyrystorami GTO zastosowany w zespole serii VT610

- Przeksztaltnik trakcyjny autobusu szynowego serii VT644 (BR644) zbudowany jest z tranzystorów IGBT i zamontowany na dachu pojazdu W jego przedniej części. W przekształtniku integrują się wszystkie układy pomiarowe (prądu, napięcia i temperatury), układy hamulca, a także zabezpieczenia uziemienia [27].
Wszystkie elementy napędowe są chłodzone powietrzem, przy czym strumień powietrza zależny jest od napięcia poszczególnych elementów [5].

Ogólny widok przekształtnika przedstawiono na rys. 34 .

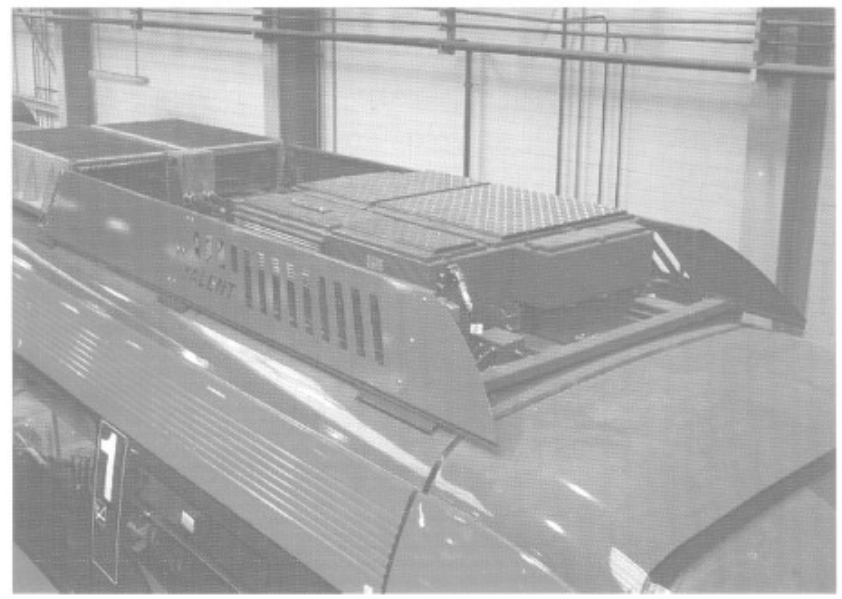

Rys.34. Przekształtnik trakcyjny autobusu szynowego serii VT644 (BR644)

Główne parametry przekształtnika są następujące:
1. napięcie obwodu pośredniego
$660 \mathrm{~V}$
2. prą znamionowy
$500 \mathrm{~A}$
3. moc znamionowa wyjściowa
$320 \mathrm{~kW}$
4. moc maksymalna
$360 \mathrm{~kW}$
5. masa (wraz z elementami chłodzenia) $440 \mathrm{~kg}$.

- Przeksztaltnik trakcyjny autobusu szynowego GTW 2/6 i 4/8 jest sprawnym urządzeniem, wykonanym w nowoczesnej technologii IGBT. Jest on modułem fazowym wyposażonym w standardowe tranzystory IGBT [22].

Urządzenia te chłodzone są wydajnym systemem wykorzystującym wode użytkowa, umożliwiając bardzo zwartą budowę. Schładzanie medium chłodzącego ma miejsce $\mathrm{w}$ wymienniku ciepła, umieszczonym na zewnątrz przekształtnika.

Dla wymuszenia obiegu powietrza i chłodzenia wewnattrz przekształtnika wbudowany jest wentylator i wymiennik ciepła: powietrze / woda.

Układy kontrolne i sterujące są zintegrowane $\mathrm{z}$ przekształtnikiem.

- Przeksztaltniki firmy Medcom (Polska) sa urządzeniami przemiennoprądowymi, zawierającymi falowniki o mocach od 100 do 600 $\mathrm{kW}$. Przekształtniki te mogą być z powodzeniem stosowane dla nowoprojektowanych krajowych autobusów z napędem spalinowoelektrycznym. 
Przekształtniki (układy napędowe serii ANT), dzięki zastosowanemu sterowaniu wektorowemu, zapewniają realizację wszystkich funkcji ruchowych pojazdu przy jednoczesnym bardzo efektywnym wykorzystaniu silników trakcyjnych. Sterowanie napędem zrealizowane jest $\mathrm{w}$ technologii DSP $\mathrm{z}$ zastosowaniem sterowania DTC. Sygnały zadające, informacyjne i alarmowe wyprowadzane są przez złącza modułowe.

\subsection{Elektryczne silniki trakcyjne}

W lekkich pojazdach szynowych i autobusach szynowych starej generacji np. zespołach VT/VS2 i VT70 stosowane są silniki trakcyjne prądu stałego, natomiast w najnowszych konstrukcjach tylko silniki prądu przemiennego, najczęściej asynchroniczne.

Poniżej podano skrótowe opisy zastosowanych oraz mających realne szanse zastosowania silników trakcyjnych w spalinowo-elektrycznych układach napędowych.

a) Silnik trakcyjny spalinowego zespołu trakcyjnego VT610 jest silnikiem asynchronicznym typu AEG BAZu 5369/4. Silnik zasilany jest bezpośrednio $\mathrm{z}$ przekształtnika trakcyjnego prądem o zmiennym napięciu i częstotliwości [4].

Ogólny widok silnika przedstawiono na rys.35.

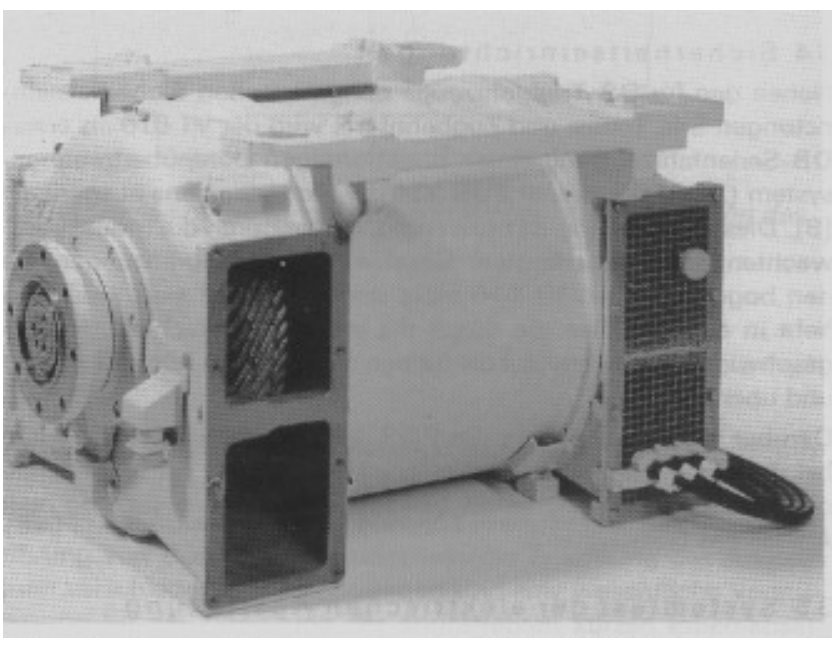

Rys.35. Silnik trakcyjny prądu przemiennego typu AEG BAZu 5369/4

b) Silnik trakcyjny spalinowego zespołu trakcyjnego BM/BS92 jest silnikiem asynchronicznym zasilanym prądem o zmiennym napięciu i częstotliwości. Silnik pracuje w warunkach optymalnych, a przeniesienie napędu przy pełnym i częściowym obciążeniu jest praktycznie stałe. Asynchroniczny zmiennoprądowy silnik jest maszyną $\mathrm{z}$ sześcioma parami biegunów o chłodzeniu obcym z klasą izolacji $\mathrm{F}$. Zastosowane rozwiązanie, przede wszystkim pełna izolacja wszystkich elektrycznych części, czyni go odpornym na wszelkie zabrudzenia [14].

Ogólny widok silnika przedstawiono na rys.36.

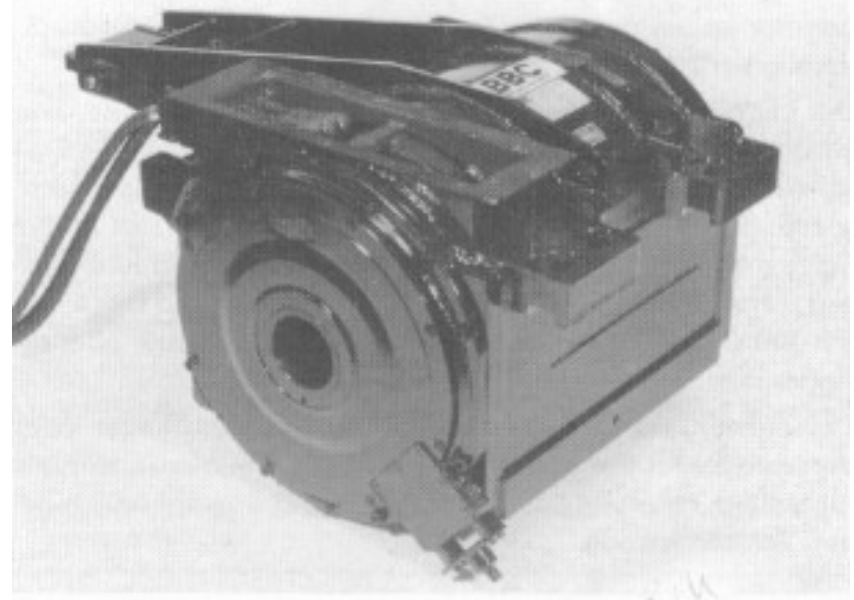

Rys.36. Silnik trakcyjny zespołu trakcyjnego BM/BS92

c) Silnik trakcyjny autobusu szynowego VT644 (BR644) jest silnikiem asynchronicznym chłodzonym wodą. $\mathrm{W}$ związku $\mathrm{z}$ tym silnik jest maszyną zamknięta, kompaktową i bardzo cichą w porównaniu z silnikami chłodzonymi powietrzem [19].

Ogólny widok silnika przedstawiono na rys.37, a jego podstawowe parametry są następujące:

1. moc znamionowa $300 \mathrm{~kW}$,

2. moc rozruchowa $330 \mathrm{~kW}$,

3. obroty: znamionowe $\quad 940 \mathrm{1} / \mathrm{min}$, maksymalne $\quad 36001 / \mathrm{min}$,

4. częstotliwość $\quad 30 \div 90 \mathrm{~Hz}$,

5. masa. $1120 \mathrm{~kg}$.

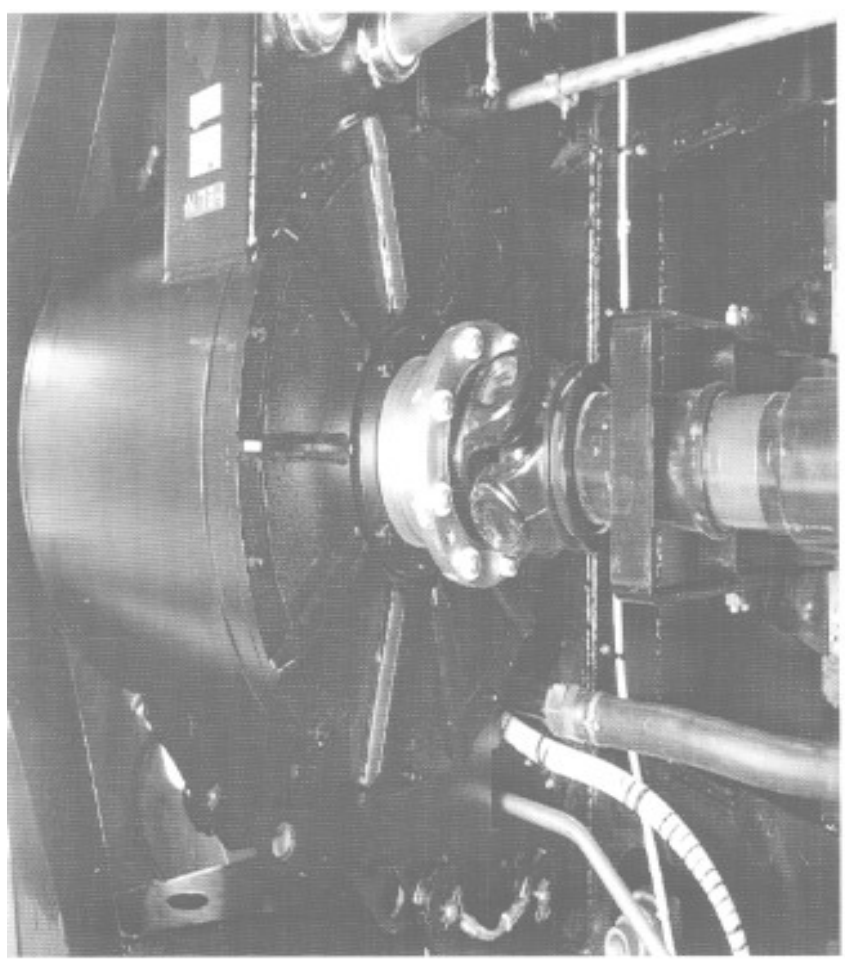

Rys.37. Silnik trakcyjny do autobusu szynowego BR644 
d) Silnik trakcyjny do autobusu szynowego GTW 2/6 i 4/8 oraz Rebus jest silnikiem asynchronicznym o szczelnej budowie. Uzwojenie wirnika ma bardzo prostą konstrukcję, w połączeniu z odpowiednią metodą produkcji jego uszkodzenia są praktycznie wykluczone. Silnik posiada wirnik klatkowy i jest odporny mechanicznie $[7,22]$.

e) Silnik trakcyjny zespołu 308B jest trójfazowym asynchronicznym silnikiem do pracy zmiennej, zasilanym przez falownik zapewniający płynną regulację siły pociagowej i prędkości. Silnik jest chłodzony powietrzem $\mathrm{z}$ wentylatora promieniowego. Powietrze do silnika doprowadzane jest kanałami elastycznymi. Silnik jest połączony bezpośrednio z przekładnią za pośrednictwem kołnierza (z pominięciem łożyska). Wałek wirnika jest połączony $\mathrm{z}$ przekładnią sprzęłem elastycznym. Silnik wyposażony jest w czujniki temperatury i prędkości obrotowej i jest zawieszony na wózkach za pośrednictwem elementów gumowo-metalowych.

Ogólny widok silnika przedstawiono na rys.38.

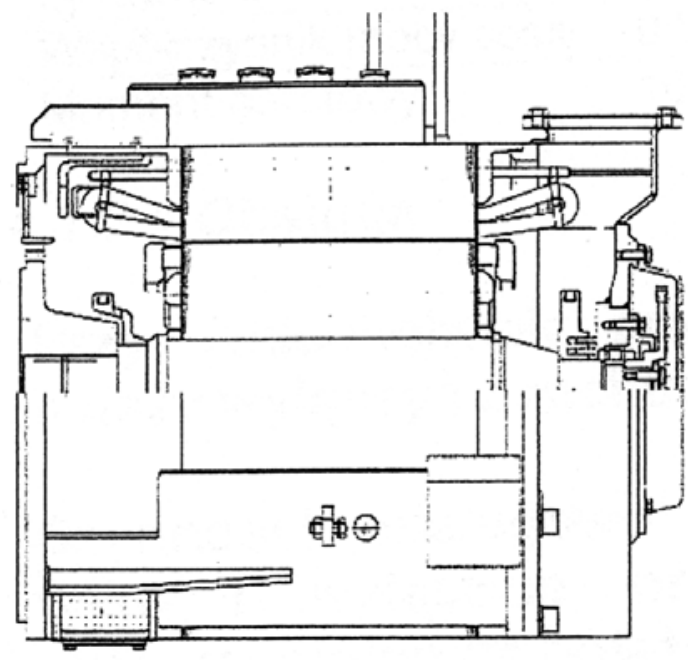

Rys.38. Silnik asynchroniczny DKLBZ 0910-04 do zespołu serii 308B

f) Silniki asynchroniczne firmy VEM Sachsenwerk są silnikami asynchronicznymi opracowanymi na bazie wcześniejszych konstrukcji dla niemieckich zespołów kolei dojazdowych. Firma VEM specjalizuje się $\mathrm{w}$ produkcji silników trakcyjnych serii DKAB2, DKCB2, DKLB2, DKVB2 i DKWB2 o mocach od 40 do $1600 \mathrm{~kW}$, napięciach do $3000 \mathrm{~V}$ i obrotach do $60001 /$ min w zastosowaniu między innymi do elektrycznych i spalinowo-elektrycznych zespołów trakcyjnych. Silniki tej firmy są przewietrzane powietrzem zewnętrznym i posiadają klasę izolacji 200. Ponadto są próżniowo i ciśnieniowo impregnowane oraz wyposażone w system nadzoru temperatury i obrotów. Silniki mogą być przystosowane do różnych rozwiązań napędowych [15].

Ogólny widok silnika przedstawiono na rys.39.

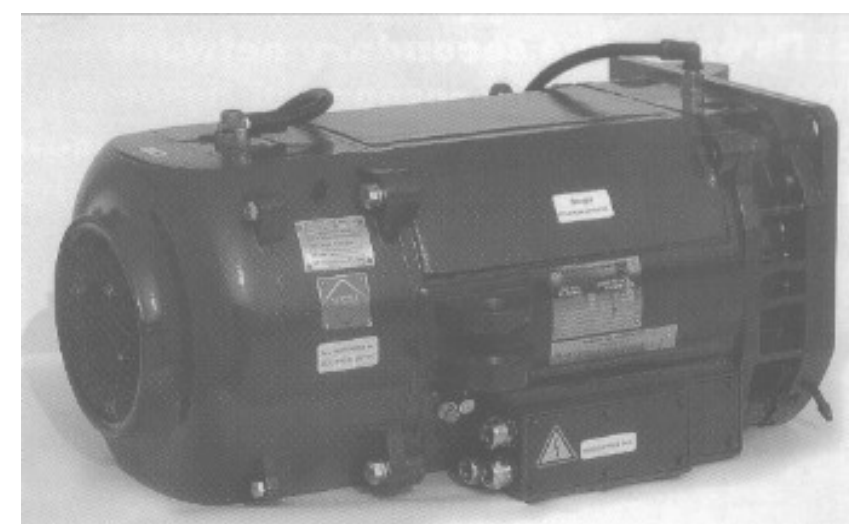

Rys.39. Silnik trakcyjny asynchroniczny firmy VEM Sachsenwerk

g) Silnik 1MLU 3441K/4 produkcji Skoda Trakcni Motory (Czechy) jest silnikiem dla lekkich pojazdów trakcyjnych. Silnik jest maszyną asynchroniczną, czterobiegunową z krótkim wirnikiem zabudowanym $\mathrm{w}$ szczelnej obudowie. Wirnik silnika jest poprzez centralne sprzęłło bezpośrednio połączony $\mathrm{z}$ wałem przekładni, łożyskowanej dwoma łożyskami.

Połączenie silnika z przekładnią jest zrealizowane przez kołnierz. Strona B wirnika łożyskowana jest łożyskami wałeczkowymi. Silnik posiada chłodzenie (przewietrzanie) własne. Izolacja próżniowociśnieniowa (VP) umożliwia pracę przy temperaturze odpowiadającej klasie cieplnej $200 \mathrm{z}$ możliwością krótkotrwałego przeciążenia do temperatury $240^{\circ} \mathrm{C}$. Silnik wyposażony jest $\mathrm{w}$ sensory temperaturowe $\mathrm{i}$ wskaźniki obrotów i może być eksploatowany w temperaturach otoczenia od $-50^{\circ} \mathrm{C}$ do $+40^{\circ} \mathrm{C}$.

Ogólny widok silnika przedstawiono na rys. 40 .

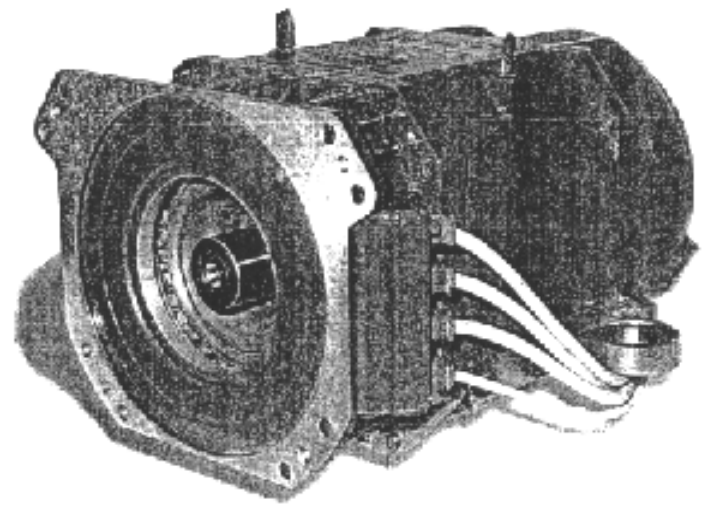

Rys.40. Silnik 1MLU 3441K/4 w zastosowaniu do lekkich pojazdów szynowych

h) Silnik trakcyjny trójfazowy firmy Emit Żychlin $\mathrm{w}$ zastosowaniu do lekkich autobusów szynowych jest silnikiem $\mathrm{z}$ wirnikiem klatkowym do bezpośredniego zasilania $\mathrm{z}$ falownika.

Silniki te cechują się następującymi właściwościami: 
- praca ciagła S1

- budowa zamknięta o stopniu ochrony wnętrza IP54

- wykonanie jednołożyskowe z jednym stożkowym czopem wału, do pracy poziomej

- kable wyprowadzone z boku tarczy o długości zabezpieczającej połączenie $\mathrm{z}$ nadwoziem

- izolacja klasy H z impregnacją uzwojenia metodą próżniowo-ciśnieniową

- wentylacja własna zabezpieczona poprzez wentylator zabudowany na wale silnika

- zastosowanie dla temperatur otoczenia od $-20^{\circ} \mathrm{C}$ do $+40^{\circ} \mathrm{C}$ i wilgotności względnej $95 \%$

- dowolny kierunek obrotów (wirowania).

Ponadto silnik może być wyposażony w czujnik temperatury uzwojenia stojana i czujnik pomiaru prędkości. Silnik posiada obecnie moc $95 \mathrm{~kW}$, przy czym jego moc może być zwiększona o dalsze kilkanaście kilowatów. Ogólny widok silnika przedstawiono na rys.41.

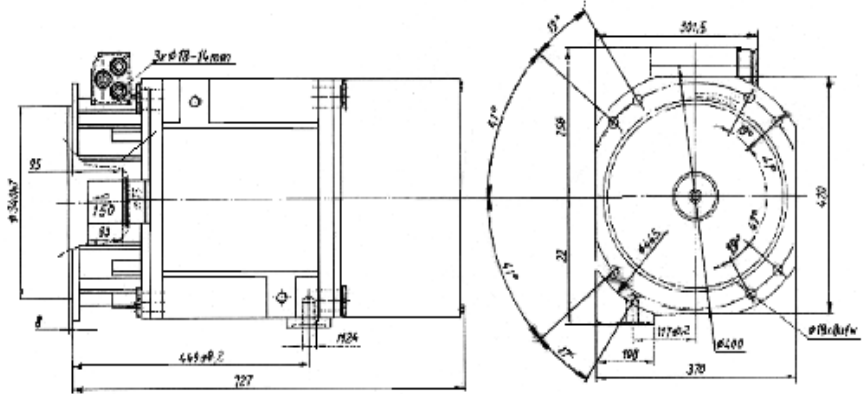

Rys.41. Silnik trakcyjny STDa 250-4A firmy Emit Żychlin w zastosowaniu do lekkich pojazdów szynowych

\subsection{Przekładnie osiowe - zespoły napędowe na wózkach}

Przekładnie osiowe, zwane często przekładniami głównymi, są ostatnim z elementów układu napędowego i przenoszą bezpośrednio moment obrotowy silnika trakcyjnego na osie napędowe zestawu kołowego lub zestawów kołowych wózka.

Konstrukcja przekładni osiowych zależy przede wszystkim od usytuowania silnika trakcyjnego. W skład przekładni, a w zasadzie wszystkich elementów i urządzeń pomiędzy silnikiem trakcyjnym a osią napędową, wchodzą: wały łączące, sprzęgła, koła zębate (walcowe, kątowe) oraz wały drążone.

Opisy wybranych przekładni- zespołów napędu na wózkach przedstawiono poniżej.

- Przeniesienie napędu zespołu trakcyjnego serii BM/BS92. Wał drążony - silnik trakcyjny jest łożyskowany w trzech punktach na ramie wózka. Obrotowo-sztywna obudowa kół przekładni podparta jest $z$ jednej strony poprzez łożyska na piaście dużego koła zębatego zestawu. $Z$ drugiej strony jest ona połączona poprzez podparcie wahliwe z ramą wózka [8].

Oba elementy typu Secheron na wale silnika i na zębniku przekładni są poprzez skrętny wał tak połączone, że tworzą układ przeniesienia momentu $\mathrm{z}$ wału drążonego i wału silnika na oś napędową zestawu kołowego.

Ponadto masy nieusprężynowane $\mathrm{w}$ wyniku takiego podparcia jednostopniowej przekładni czołowej są bardzo małe. Również całkowite odsprężynowanie silnika trakcyjnego zabezpiecza obudowę przekładni głównej od działania drgań.

- Przeniesienie napędu w autobusach serii GTW 2/6, 4/8 oraz Rebus. Stosowane są przekładnie dwustopniowe z kołami zębatymi osadzonymi na osi. W nowocześniejszych rozwiązaniach napęd $\mathrm{z}$ silnika przenoszony jest poprzez przekładnię, wał drążony i klinowe sprzęgło płytkowe. Sprzęgło to przejmuje jednocześnie zadanie kompensowania przemieszczeń między zespołem napędowym a osią zestawu kołowego, wynikających $\mathrm{z}$ ugięć usprężynowania i dynamiki ruchu. Zespół silnik trakcyjny - przekładnia podparty jest na wózku poprzez elastyczne elementy złączne [22].

- Przeniesienie napędu KERF w wózkach jednoosiowych. Układ ten jest układem uniwersalnym i możliwym do zastosowania $\mathrm{w}$ autobusach szynowych jak i w szybkich kolejach miejskich. Moment obrotowy z silnika trakcyjnego, zawieszonego za nos (na ramie wózka i na osi zestawu kołowego), przenoszony jest na napędowy zestaw kołowy za pośrednictwem jednostopniowej przekładni zębatej o kołach walcowych [16].

Ogólny układ napędu zabudowanego na wózku przedstawiono na rys. 42 .

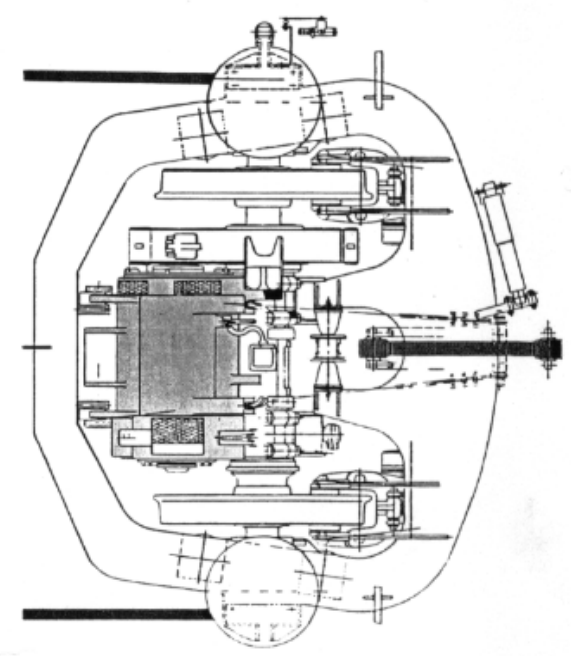




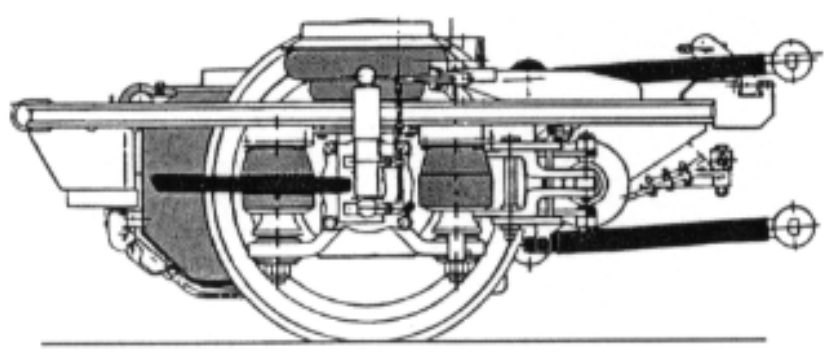

Rys.42. Zespół napędu KERF dla wózków jednoosiowych

- $\quad$ Przeniesienie napędu w zespole serii 308. Zespół ten, mimo że jest stosowany w elektrycznym autobusie szynowym, może być $\mathrm{z}$ powodzeniem zastosowany również $\mathrm{w}$ autobusach szynowych i lekkich pojazdach szynowych z napędem spalinowo-elektrycznym.

Ogólny widok zespołów zabudowanych na wóz$\mathrm{ku}$ dwuosiowym przedstawiono na rys.43, a jego główne elementy na rys. 44 .

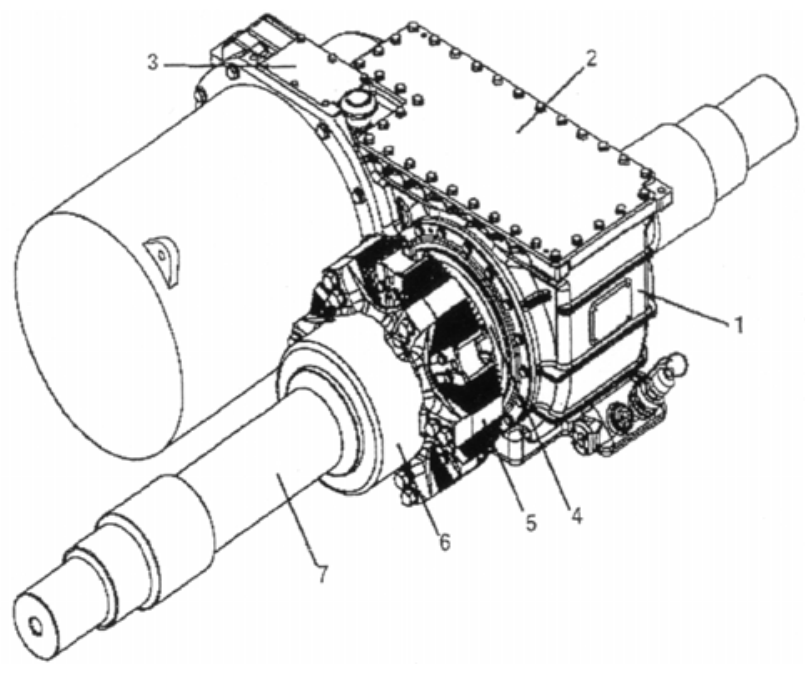

Rys.44. Główne elementy zespołu napędowego 1 - obudowa przekładni; 2 - pokrywa przekładni; 3 - pokrywa dodatkowa; 4 - wał drążony; 5 - wkładka gumowa; 6 - krzyżak półosi, 7 - półoś napędowa
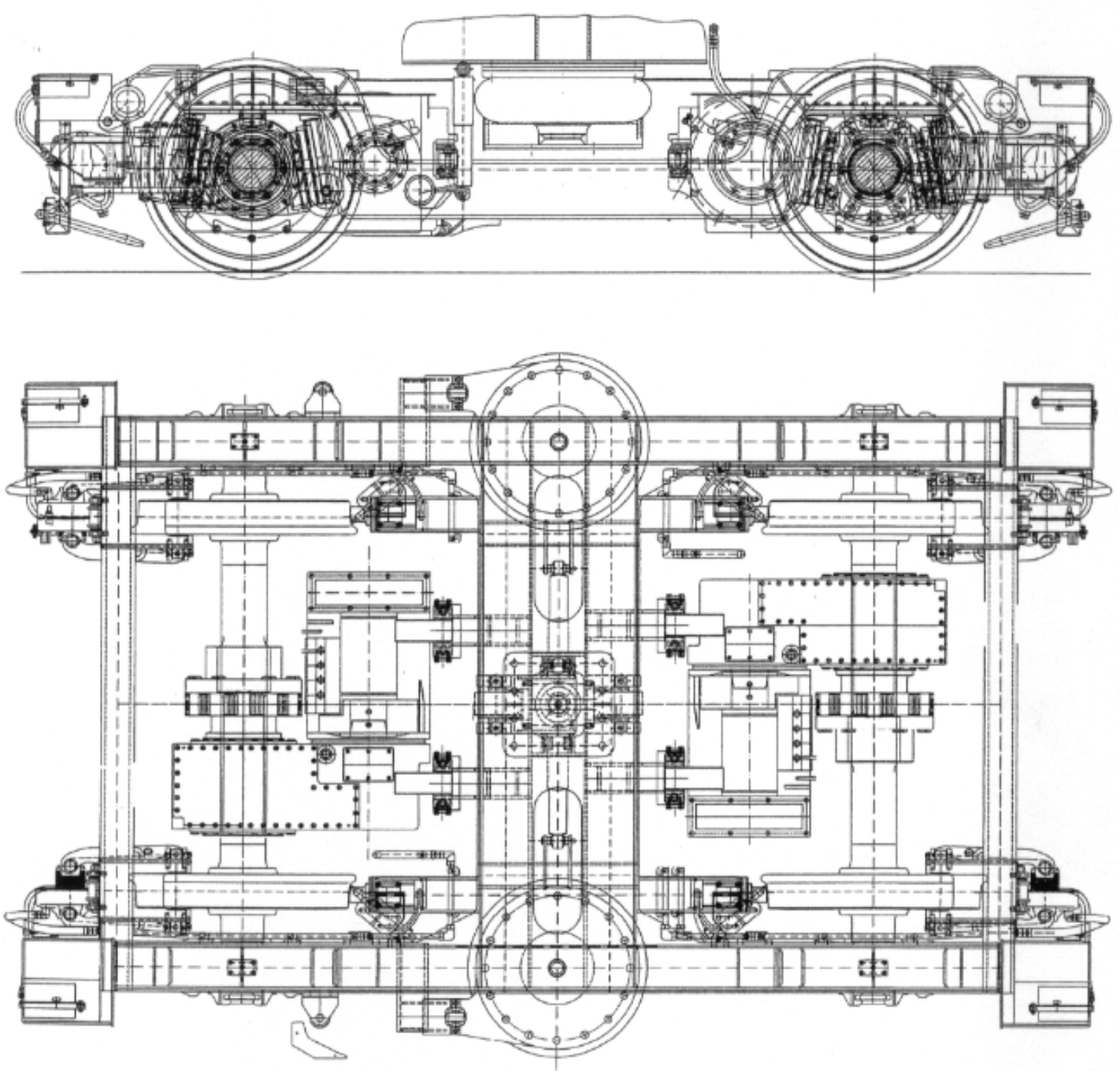

Rys.43. Ogólny widok dwuosiowego wózka z zabudowanymi zespołami napędowymi 
Głównym elementem zespołu napędowego jest dwustopniowa przekładnia napędowa Voith (model SHZ 495) z zębatym kołem czołowym. Zespół jest zawieszony poprzecznie na łącznikach elastycznych, a silnik trakcyjny połączony jest z przekładnią równolegle do półosi napędowych.

Moment obrotowy (napędowy) przekazywany jest z silnika elektrycznego do przekładni poprzez sprzęłło oddziaływujące bezpośrednio na półosie napędowe i dalej na koła poprzez stopnie przekładni i przegub klinowy na półosi napędowej.

Wał drążony z przegubem klinowym przejmuje jednocześnie zadanie równoważenia przemieszczeń pomiędzy zespołem napędowym a półosią napędową.

Podstawowe parametry techniczne przekładni sa następujące:
1. przełożenie
$1: 4,68$
2. prędkość wejściowa
$5150 \mathrm{obr} / \mathrm{min}$
3. moment maks. $2902 \mathrm{Nm}$
4. masa przekładni (bez oleju)
$630 \mathrm{~kg}$
5. ilość oleju
7,21 .

- Przeniesienie napędu $z$ wykorzystaniem przekladni firmy Voith Turbo.

Firma Voith specjalizuje się w produkcji (poza przekładniami hydraulicznymi) przekładni osiowych oraz innych elementów służących do przeniesienia momentu obrotowego z silnika trakcyjnego na oś zestawu kołowego [25].

Przykładami takich napędów między innymi są:

- napęd kolei podmiejskiej

- napęd zespołu kolei greckiej.

Oba opisane przykłady mogą z powodzeniem być zastosowane również $w$ autobusach szynowych. Pierwszy z nich przedstawiono na rys. 45 .

a)

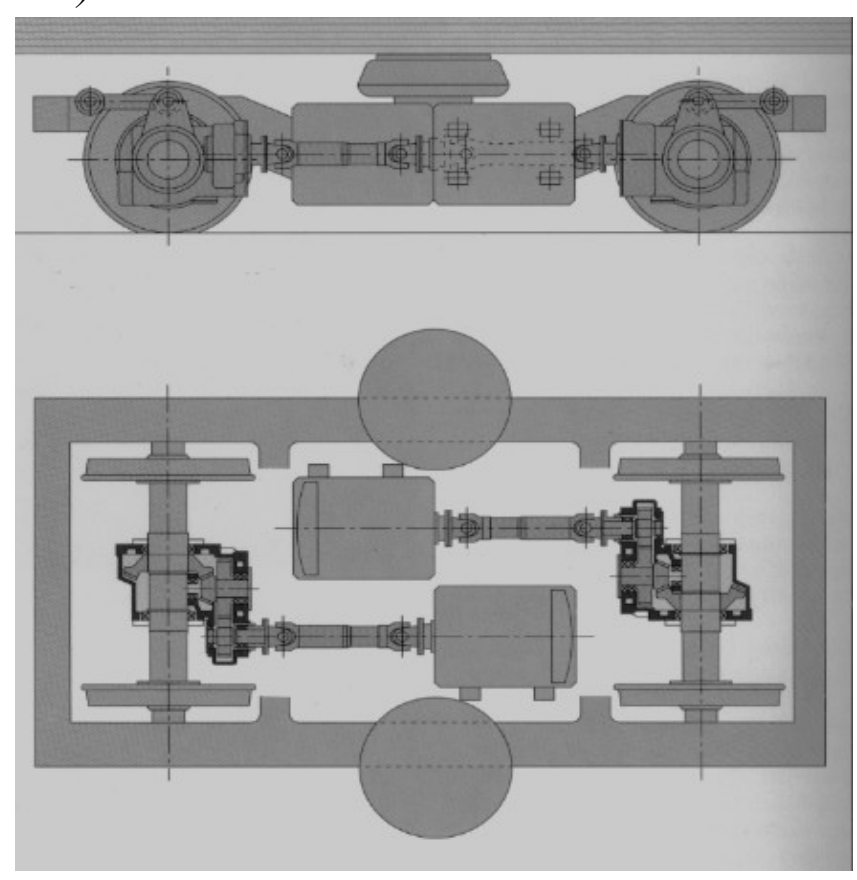

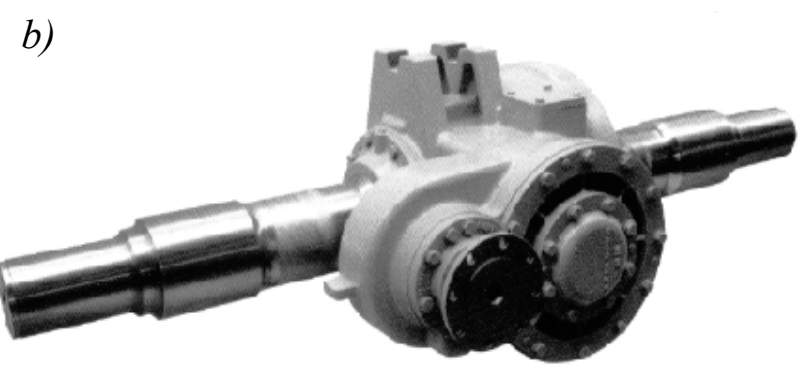

Rys.45. Przekładnia firmy Voith Turbo dla kolei podmiejskiej: a) zabudowa na wózku, b) ogólny widok

Zastosowana przekładnia jest przekładnią osiową dwustopniową walcową i stożkową. Silniki zawieszone są wzdłużnie i napędzają za pośrednictwem wałów przegubowych pojedyncze zestawy kołowe wagonu silnikowego. Moc każdego silnika wynosi $205 \mathrm{~kW}$, a prędkość maksymalna pojazdu nie przekracza 100 $\mathrm{km} / \mathrm{h}$.

Producentem silników jest firma AdtranzAsynchronmotor. Dzięki zastosowaniu takiego układu napędowego maksymalny nacisk zestawu kołowego na tor nie przekracza $14 \mathrm{t}$.

Drugi z przykładów układu napędowego zastosowanego $\mathrm{w}$ zespole kolei greckich przedstawiono na rys. 46 .
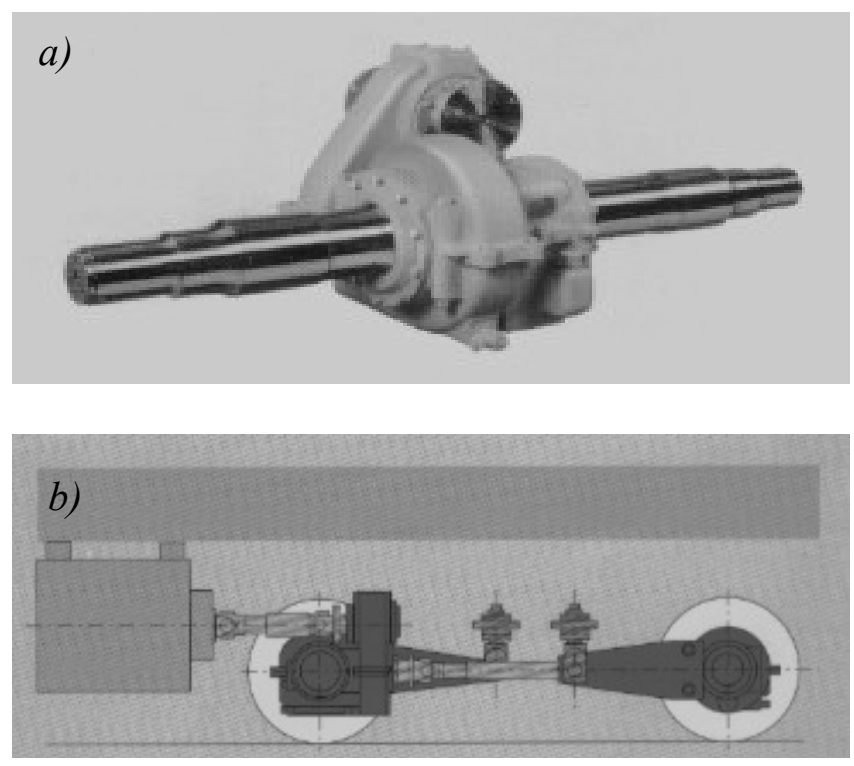

Rys.46. Przekładnia firmy Voith Turbo dla zespołu kolei greckich: a) ogólny widok; b) zabudowa pod ostoją

Zespół napędowy tworzy przekładnia osiowa $\mathrm{z}$ walcową przekładnią pośrednią, stożkową przekładnią rozdzielającą typu V15/19 oraz przekładnią stożkową typu E15/19.

Silnik trakcyjny jest zawieszony na ramie pojazdu i napędza obie osie za pośrednictwem wału przegubowego. Stosując jeden silnik trakcyjny na wózku napędowym uzyskuje się korzystne wskaźniki masy oraz ceny. 
Poprzez całkowite oddzielenie podwójnie zawieszonej masy silnika od osi zestawu kołowego, masa wózka napędowego jest w istotnym stopniu zredukowana. Zaletą jest także centralne ustalenie przekładni osiowej na osi zestawu kołowego. Przy zastosowaniu takiego zespołu silnik spalinowy, prądnica, prostownik i przekształtnik mogą być zabudowane w przedziale maszynowym wewnątrz pojazdu [26].

- Przeniesienie napędu z wykorzystaniem przekładni firmy ZF Hurth Bahntechnik

Firma ZF Hurth (Niemcy) specjalizuje się w produkcji przekładni osiowych zarówno z kołami walcowymi jak i z kołami stożkowymi.

$\mathrm{W}$ zespołach napędowych $\mathrm{z}$ wykorzystaniem tych przekładni zastosowane są ponadto wały przegubowe, wały drążone i sprzęgła elastyczne $[20,24]$.

Ogólny widok przekładni firmy ZF Hurth przedstawiono na rys.46 i 47.

Przekładnia czołowa przedstawiona na rys.46 przenosi napęd na oś zestawu kołowego za pośrednictwem krótkiego wału drążonego i sprzęgła, na którym zabudowana jest również tarcza hamulcowa.

a)
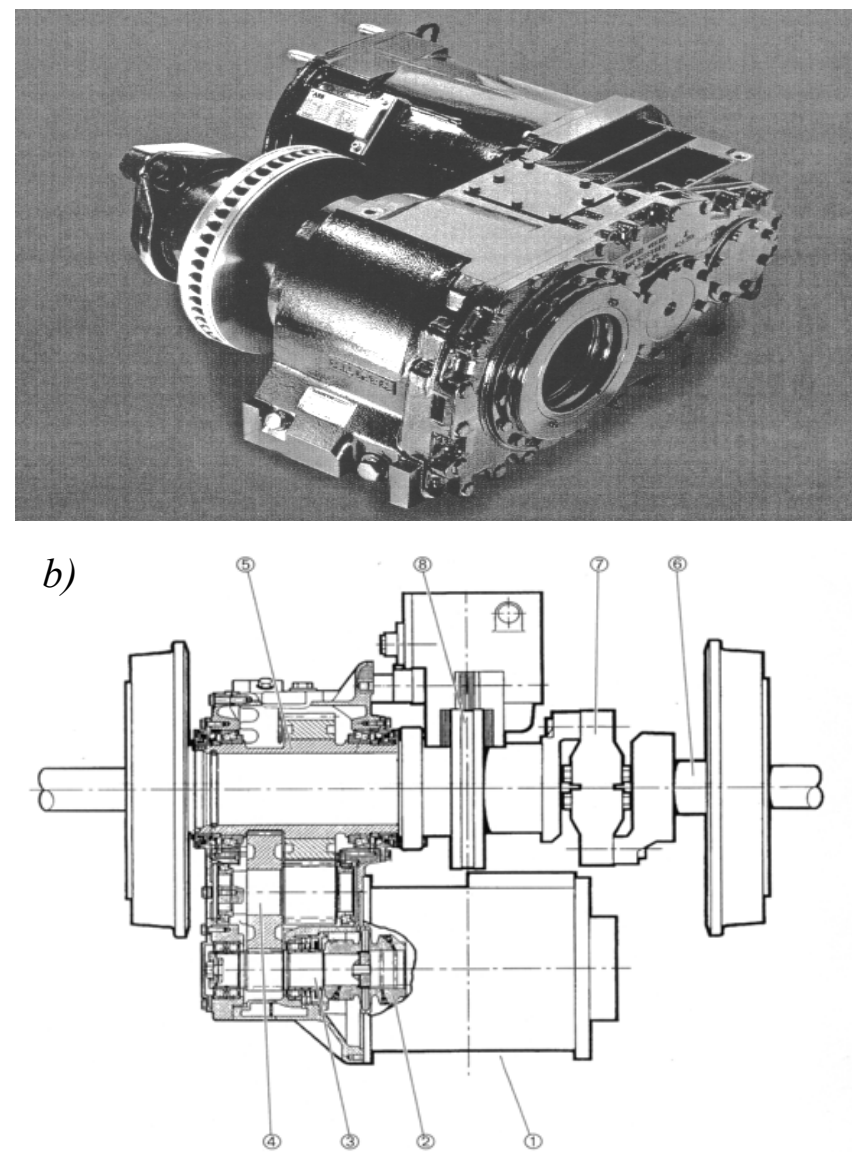

Rys.46. Zespół napędowy HSHL8-175 firmy ZF Hurth a) Ogólny widok; b) przekrój: 1 - silnik trakcyjny, 2 sprzęgło membranowe, 3 - zębnik, 4 - koło pośrednie; 5 wał drążony przekładni, 6 - oś zestawu kołowego, 7 sprzęgło, 8 - tarcza hamulca.
Zespół napędowy przedstawiony na rys. 47 tworzą silnik trakcyjny, przekładnia oraz wał drążony i sprzęgła elastyczne. Zespół ten znalazł zastosowanie w szybkich kolejach miejskich oraz wagonach metra.

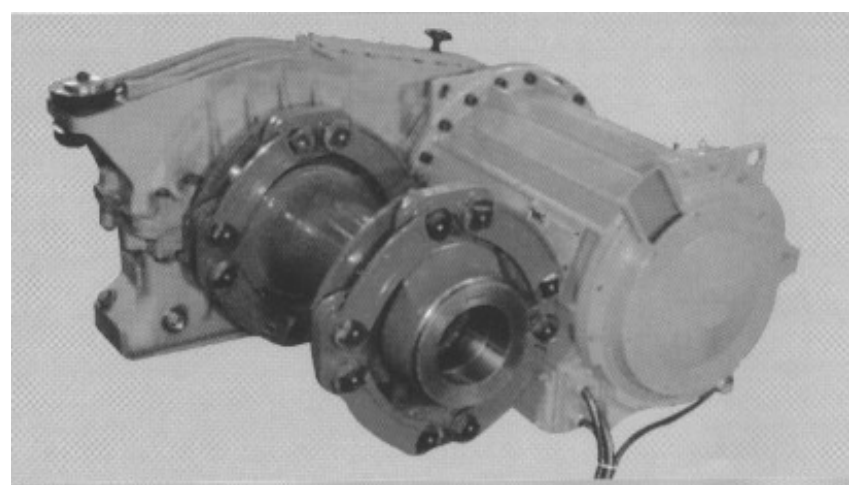

Rys.47. Zespół napędowy firmy ZF Hurth dla szybkiej kolei miejskiej

Pozostałe przykładowe rozwiązania zespołów napędowych $\mathrm{z}$ wykorzystaniem przekładni osiowych $\mathrm{z}$ kołami walcowymi firmy ZF Hurth przedstawiono na rys. $48 \div 50$.

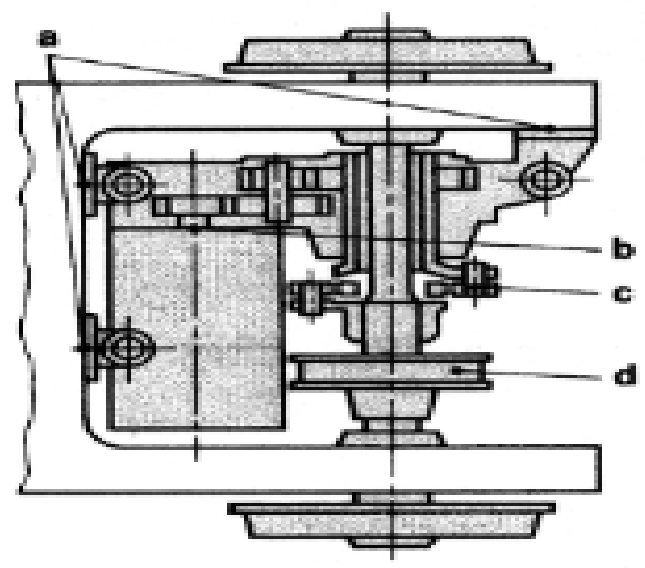

Rys.48. Napęd ZF Hurth z wałem drążonym $\mathrm{a}$ - zawieszenie na ramie wózka, b - połączenie sztywne silnika i przekładni, c - sprzęgło kierujące, d - tarcza hamulcowa

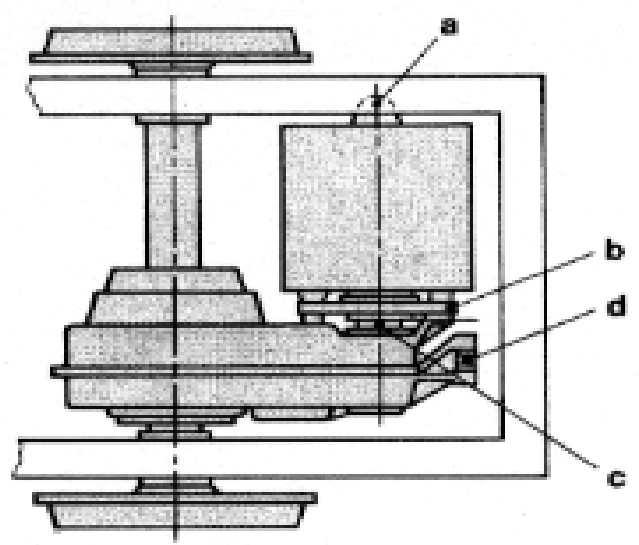

Rys.49. Napęd ZF Hurth ze sprzęgłem zębatym a - zawieszenie elastyczne silnika na ramie wózka, b sprzęgło zębate, c - połączenie elastyczne silnika z przekładnią, d-podparcie przekładni. 


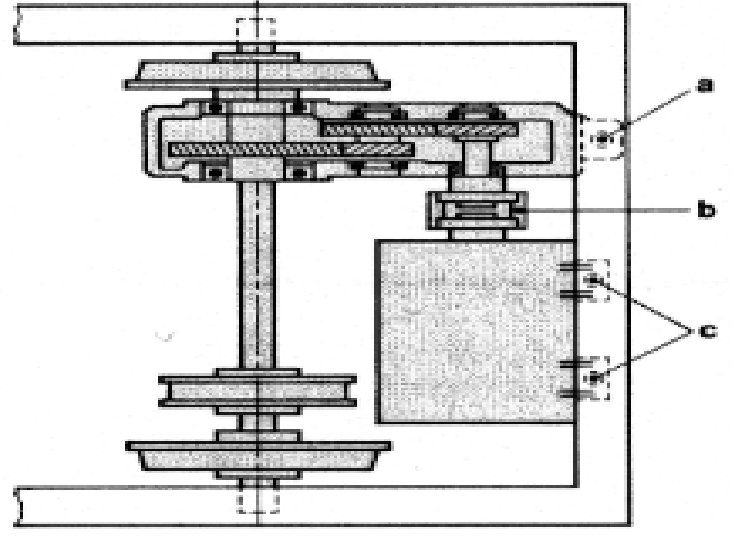

Rys.50. Napęd ZF Hurth ze sprzęgłem elastycznym a - zawieszenie przekładni, b - sprzęgło elastyczne, c sztywne zawieszenie silnika na ramie wózka

Rozwiązanie napędu $\mathrm{z}$ wykorzystaniem przekładni stożkowych firmy ZF Hurth wraz z przykładami jej zabudowy na wózkach dwuosiowych przedstawiono na rys. $51 \div 53$.

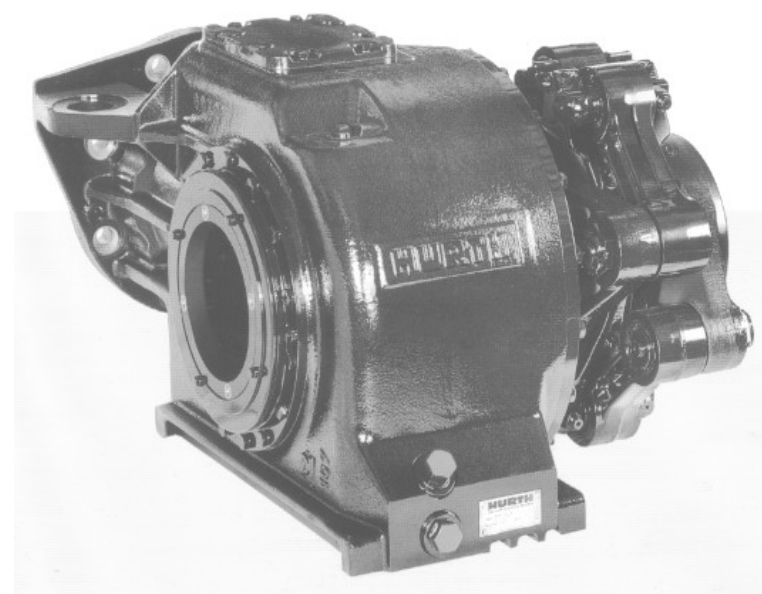

Rys.51. Ogólny widok przekładni stożkowej typu HK firmy ZF Hurth a)

Dwuosiowy napęd wzdłużny $\mathrm{z}$ przekładnią HKH (silnik połączony z obiema przekładniami),

\section{b)}

Dwuosiowy napęd wzdłużny $\mathrm{z}$ przekładnią HSK (silnik zawieszony na ramie),

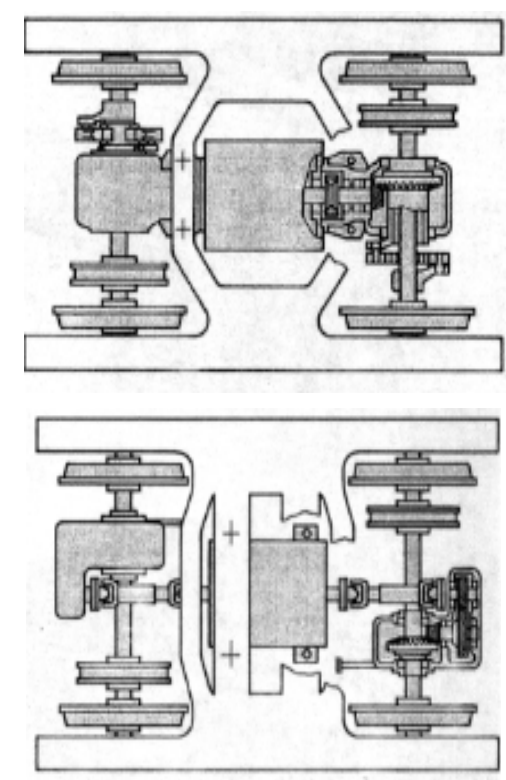

c)

Pojedynczy napęd wzdłużny $\mathrm{HKF} / \mathrm{HKHF}$ (silnik zawieszony na wózku),

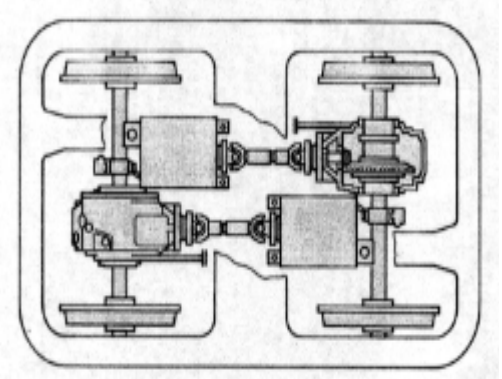

Pojedynczy napęd wzdłużny $\mathrm{z}$ przekładnią HKH (silnik zawieszony na wózku). d)

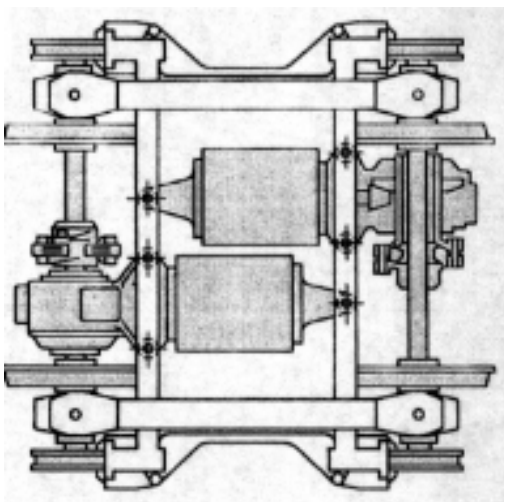

Rys.53. Przykładowe rozmieszczenie napędów z wykorzystaniem przekładni stożkowych firmy ZF Hurth

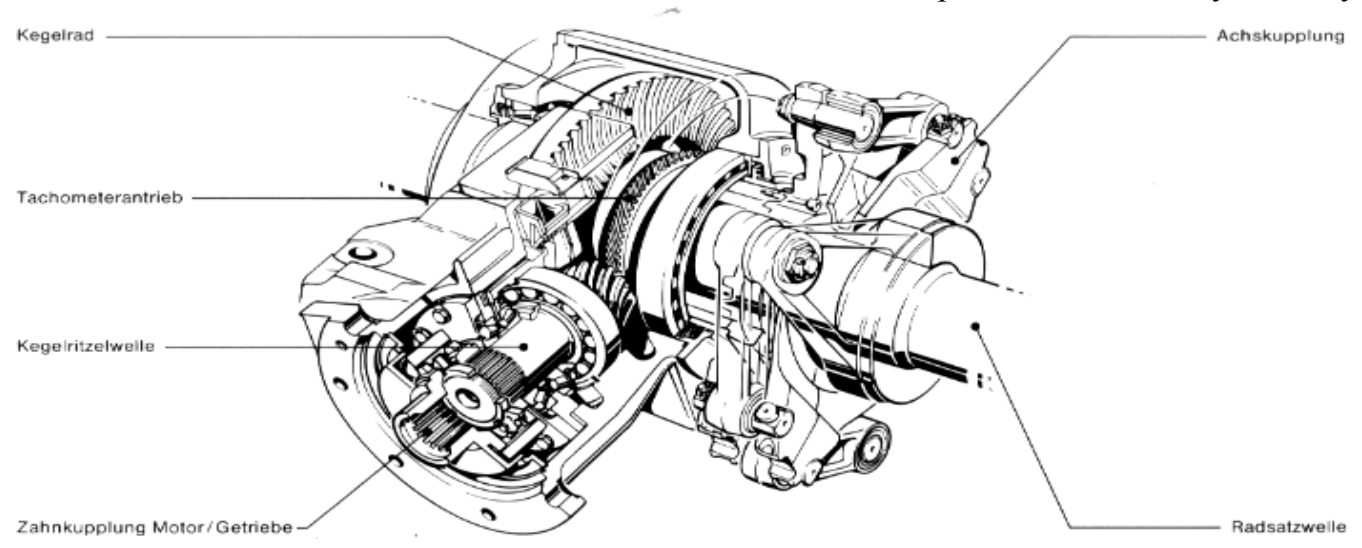

Rys.52. Przekrój przez przekładnię firmy ZF Hurth [24]

Kegelrad - koło stożkowe; Tachometerantrieb - napęd szybkościomierza; Kegelritzelwelle - wał zębnika stożkowego; Zahnkupplung Motor/ Getriebe - sprzęgło zębate silnik/przekładnia; Achskupplung - sprzęgło osi zestawu kołowego; Radsatzwelle - oś zestawu kołowego 
- Przeniesienie napędu $\mathrm{z}$ wykorzystaniem przekladni firmy Flender (Austria)

Podobne w budowie i przeznaczeniu są również przekładnie i zespoły napędowe oferowane przez firmę Flender. W obu przykładowych rozwiązaniach przedstawionych na rys.54 i 55 napęd przenoszony jest $\mathrm{z}$ silnika trakcyjnego (ustawionego równolegle do osi zestawu kołowego i zawieszonego elastycznie na ramie wózka) na zestaw kołowy za pośrednictwem dwustopniowej przekładni z kołami zębatymi walcowymi, wału drążonego oraz sprzęgieł elastycznych.

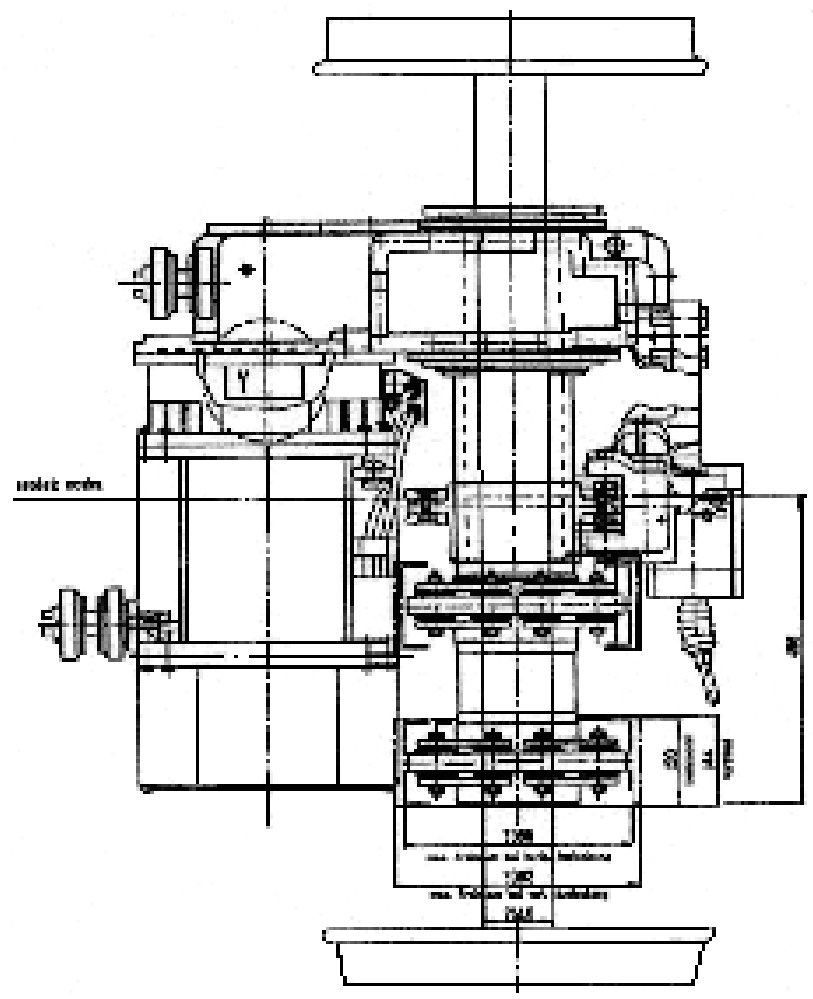

Rys.54. Napęd zestawu kołowego z wykorzystaniem przekładni firmy Flender

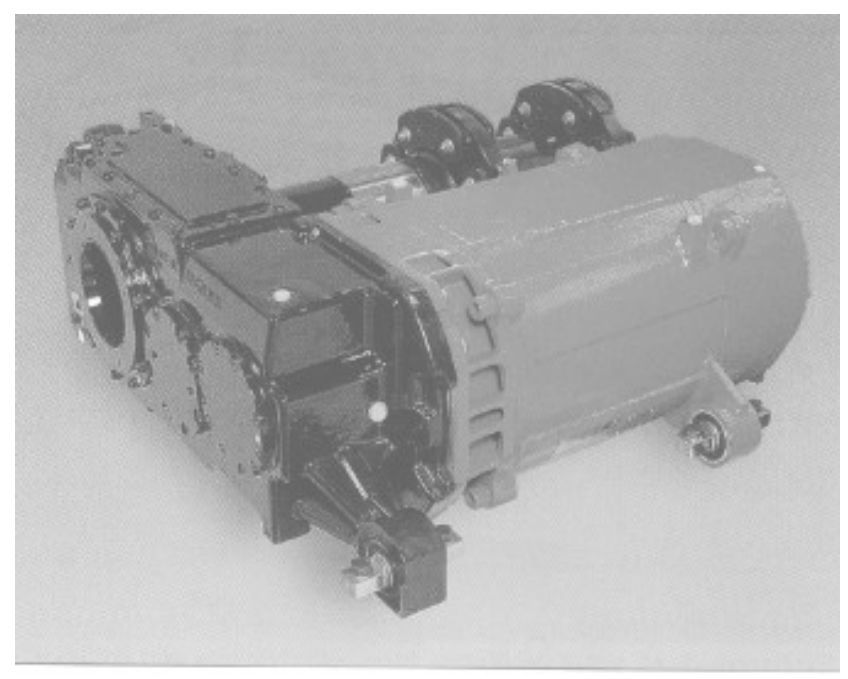

Rys.55. Ogólny widok przekładni firmy Flender zamocowanej do silnika trakcyjnego

\section{PODSUMOWANIE}

Zaprezentowane rozwiązania konstrukcyjne spalinowo-elektrycznych układów napędowych do lekkich wieloczłonowych pojazdów szynowych - spalinowych zespołów trakcyjnych i autobusów szynowych zagranicznej produkcji - sprawdzily się w eksploatacji. Świadczy o tym zarówno ich wysoka ocena techniczna i eksploatacyjna, jak i coraz większe zamówienia u producentów, wytwarzających zwłaszcza autobusy szynowe.

Należy zaznaczyć, że prezentowane konstrukcje układów (zarówno podpodłogowe typu power-pack jak i wewnątrz pojazdowe - zabudowa w specjalnym module napędowym) między innymi takich firm jak Stadler, Bombardier, Talbot i innych cechują się prostotą konstrukcji, minimalnym oddziaływaniem na środowisko naturalne, minimalnymi kosztami eksploatacji, utrzymania i napraw, a przede wszystkim wysoką niezawodnością i trwałością.

Obecnie również w kraju obserwuje się (na razie niewielkie) zainteresowanie potencjalnych użytkowników nowoczesnymi spalinowo-elektrycznymi układami napędowymi.

Wychodząc naprzeciw producentom przyszłych autobusów szynowych w Instytucie Pojazdów Szynowych „Tabor” w Poznaniu rozpoczęto prace wstępne (koncepcyjno-założeniowe) nad nowoczesnymi układami napędowymi zarówno w wersji podpodłogowej jak i do zabudowy wewnątrz pojazdu.

W pierwszym wariancie zostaną wykorzystane doświadczenia $\mathrm{z}$ projektowania i wdrażania autobusów szynowych jedno-, dwu- i trzyczłonowych $(210 \mathrm{M}, 211 \mathrm{M}, 212 \mathrm{M})$ zaprojektowanych w IPS-ie i wyprodukowanych (tylko jednoczłonowy - SA107 i dwuczłonowy - SA109) przez byłe Zakłady „Kolzam" w Raciborzu [10]. W projekcie tym zostaną stworzone podstawy do wykonania krajowej konstrukcji układu Power-Pack do zabudowy w dostępnej obecnie $\mathrm{w}$ autobusach przestrzeni przed jednoosiowym wózkiem napędowym, $\mathrm{z}$ zabudową dachową prostownika, zabudową przekształtnika i hamulca elektrodynamicznego. Ponadto zamierza się stworzyć projekty napędów z wykorzystaniem wózków dwuosiowych.

W drugim wariancie przewidywane jest opracowanie układu napędowego zabudowanego w specjalnym module napędowym. Moduł ten zostanie zabudowany bezpośrednio za jedną z kabin sterowniczych. Wybór takiego usytuowania modułu podyktowany został wysokimi wymaganiami wytrzymałościowymi do spełnienia przez części przednie autobusów przy nabieganiu z prędkościami do $15 \mathrm{~km} / \mathrm{h}$ (brak deformacji konstrukcji) i z prędkościami $15 \div 30 \mathrm{~km} / \mathrm{h}$ (deformacja pudła od czoła do początku pomieszczeń pasażerskich).

Największym atutem budowy takich krajowych układów napędowych jest to, że poza silnikiem spali- 
nowym wszystkie pozostałe maszyny i zespoły moga być wykonywane przez krajowych producentów np.: Emit Żychlin, Medcom. W kraju są również potencjalni wytwórcy autobusów tj. Pesa Bydgoszcz, ZNTK Poznań i Bumar-Fablok. Szczegółowe propozycje, jak również parametry głównych maszyn i zespołów układów napędowych spalinowo-elektrycznych $\mathrm{w}$ zastosowaniu do krajowych autobusów szynowych, obejmujących wszystkie konfiguracje napę$\mathrm{du}$, zostaną przedstawione w oddzielnym artykule.

\section{Literatura}

[1] Bula Z.; Marciniak Z.: Rodzina autobusów szynowych do ruchu lokalnego. Materiaty XIV Konferencji Naukowej „Pojazdy Szynowe 2000” Kraków Artamów 2000.

[2] Cortesi A.; Meier U.; Noack V.; Schönberg S.; Wieser U.: Der Gelenktriebwagen GTW 2/6, eine Neuentwicklung für den Regionalverkehr, ZEV+DET Glas. Ann, nr 3, 1995.

[3] Dompke T.; Rose R D.; Matthaei W.: Der dieselelektrische Triebwagen VT/VS $2 E$ der Hessischen Landesbahn GmbH, ETR, 1988, nr 11.

[4] Fischer H.; Maier M.: Der neue dieselelektrische Triebzug der Baureihe VT610 der Deutschen Bundesbahn mit gleisbogenabhängiger Wagenkastensteuerung. ZEV+DET Glas Ann, nr 7/8, 1991.

[5] Hondius: Der dieselelektrische S-Bahnzug BR644 für DB AG. Stadtverkehr, $n r$ 7/8, 1998.

[6] Kattner A.: MAN - Motoren für Bahneinsatz ZEV+DET Glas Ann, nr 2/3, 2000.

[7] Kućmin J.; Skalski S.: Rebus - autobus szynowy z Adtranz Pafawag dla PKP, Przeglad Kolejowy, nr 5, 1998.

[8] Matthaei W.: Elektrische Ausrüstung für dieselelektrischen Triebzüge BM/BS92 der Norwegischen Staatsbahnen, ZEV - Glas Ann, nr 12, 1984.

[9] Mäfner F.; Matthias M.; Mittmann U.; Schäfer L.: Elektrische Ausrüstung der Dieseltriebzüge Baureihe 610 der Deutschen Bundesbahn; Elektrische Bahnen, nr 7, 1993.

[10] Marciniak Z.: Modułowa konstrukcja wieloczłonowych autobusów szynowych do ruchu lokalnego. Pojazdy Szynowe nr 2/2003.

[11] Marciniak Z.: Propozycja układu napędowego dla krajowych autobusów szynowych do ruchu regionalnego, Pojazdy Szynowe, nr 2/2004.
[12] Marciniak Z.: Układy napędowe krajowych autobusów szynowych do ruchu lokalnego, Pojazdy Szynowe, 3/2003.

[13] Nortvedt E.: Erster dieselelektrischer Triebzug mit Drehstrohmantriebstechnik im Betriebseinsatz bei den Norwegischen Staatsbahnen . ETR, nr 6, 1987.

[14] Nortvedt E.; Fischer H.: Neue zweiteilige Dieseltriebzüge BM/BS92 mit Drehstrohmantriebstechnik für die Norwegischen Staatsbahnen (NSB), ZEV-Glas. Ann, 1984, nr 12.

[15] Proske J.: Innovative Traction Motor Servies for Low-Floor-Vehicale. Railvolution, nr 3, 2005.

[16] Rose R. D.: Die Entwicklung und Erprobung kurvengesteuerter Einzelradsatz - Fahrwerke „KERF”. ZEV+DET Glas. Ann. 1994, nr 6.

[17] Stiefel S.; Sauer O.; Prokisch G.: Die TALENT Familie - die flexible Lösung für alle Fragen des Regionalverkehrs, ZEV+DET Glas. Ann. nr 9/10, 1998.

[18] Valent I.: AGC - Autorail Grande Capacite. Railvolution, $n r$ 3, 2005.

[19] Wolf J.: Der dieselektrische S-Bahnzug BR644 für die DB AG, Stadtverkehr, $n r$ 7/8, 1998.

[20] Antriebstechnikfür Schienenfahrzeuge. Komfort auf allen Gleisen. Materialy firmy ZF Hurth Bahntechnik GmbH.

[21] Cummins diesels for railcar application 212 to 12000 bhp. Materiaty firmy Cummins.

[22] Diesel-Elektrischen Niederflur-Gelenktriebwagen GTW 2/6 und 4/8 für den Regionalverkehr. Materiały firmy Adtranz, DWA, SLM, Stadler.

[23] Dieselmotoren $6 H 1800$ für Bahnanwendungen. Materiaty firmy MTU.

[24] Kegelradachsgetriebe Baureihe HK. Stirnradachsgetriebe Baureihe HS. Materiaty firmy ZF Hurth Bahntechnik GmbH.

[25] Mechanische Antriebskomponenten in Schienenfahrzeugen. Materiaty firmy Voith Turbo $\mathrm{GmbH}$.

[26] Napędy pojazdów szynowych. Materiały firmy Voith Turbo GmbH.

[27] Поезgа семейстьа Talent. Железные gороги мupa. $n$ r 8, 1999.

[28] Produkte / Systeme - Dieselmotoren, Gasmotoren und Gasturbinen. Materiaty firmy MTU.

[29] Karta UIC 505-1 Pojazdy kolejowe. Skrajnia pojazdów. Wyd. 9 z listopada 2003.

[30] Norma PN-EN 12663:2002 Kolejnictwo. Wymagania konstrukcyjno-wytrzymatościowe dotyczace pudet kolejowych pojazdów szynowych.

[31] Karta UIC 624 Badanie emisji gazów wydechowych silników spalinowych trakcyjnych. Wydanie 2, kwiecień 2003. 